\title{
THE ORIGINAL IDENTITY OF THE YORK AND TOWNELEY CYCLES
}

A THESIS SUBMITTED TO THE PACULTY OF THE GRADUATE SCHOOL. OF THE UNIVERSITY OF MINNESOTA

BY

MARIE CAROLINE LYLE

IN PARTIAL PULPLLLMENT OF THE REQUIREMBNTS FOR THE DEGREE OF DOCTOR OF PHILOSOPHY

1917 
Research Publications of the University of Minnesota Vol. VIII No. 3

Studies in Language and Literature

Number 6

\section{THE ORIGINAL IDENTITY OF THE YORK AND TOWNELEY \\ CYCLES}

BY

MARIE C. LYLE, Ph.D.

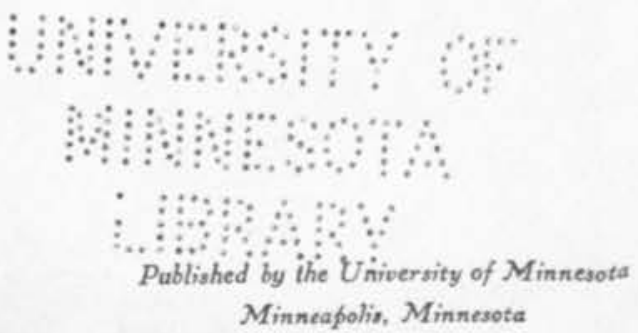




\section{COPYRIGHT 1919 \\ BY THE \\ University of Minnesota}

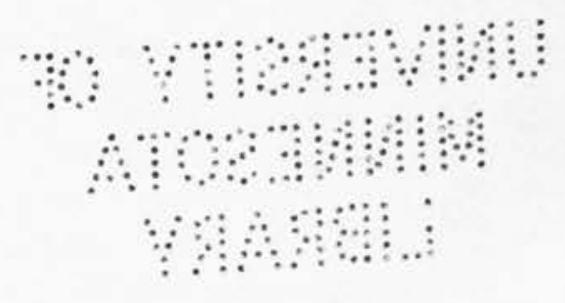




\section{PREFACE}

The theory of the formation of cycles of mystery plays held by earlier students of the subject, by even so great a scholar as Ten Brink, was that they were written by various individual authors at various places and were collected into groups much as Elizabethan or other plays are collected. Each play, it was believed, had its own author, place, and date of composition, which modern investigation might possibly discover. The wide variety of style, period, and even of dialect, exhibited within a single cycle, to say nothing of the many indications of the work of a single author, was regarded as a sufficient basis for such a conception and historians of literature have never rid themselves entirely of a theory of individual authorship for mystery plays.

The particular forms in which the mystery plays come down to us are not the work of single authors, but of redactors, revisers, and mere tinkerers, showing the results of many changes and modifications of the work of older and simpler originals. Plays on the same subject present the variety of treatment that different versions of the same popular ballad present, and the problem of determining the original form is not different in the one case from what it is in the other.

In the thesis which follows, I endeavor to explain the problem presented by the tangled series of agreements and differences between two of the more important documents in early English literature. From various evidences in the forms preserved and from the scanty historical records of the gilds responsible for the acting of the plays, I attempt to discover the relationship between the two great cycles of Yorkshire plays, and arrive at the conclusion that, at an earlier period, the York cycle and the Towneley cycle were, as cycles, one and the same. It is, thus, at variance with the current theory of the borrowing of individual plays from the one cycle and the incorporation of them into the other. If my thesis finds general acceptance, we shall hear less of plays "borrowed" in such odd and unaccountable groups from the York cycle by the Towneley cycle, and in the study of other cycles critics may apply the same theory of continuous revision of individual plays, due to craft control or to other reasons. In this connection, the recent article published in Modern Philology (January, 1918) by Mrs. Frank points the way. This article appeared after the presentation of my thesis to the Faculty of the University of Minnesota (June, 1917), but in my revision of it for publication I have availed myself of certain evidence submitted by her.

The thesis was undertaken and written under the direction of Professor Hardin Craig. It has since, in his absence, been revised for publication under the direction of Professor Carleton Brown. Both of them have

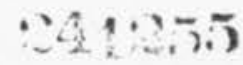


shown the most generous spirit of helpfulness, interesting themselves in the detail as well as the general outlines of the work; and I welcome this opportunity to make public and grateful acknowledgment of my indebtedness to both of them, and especially to Professor Craig, without whose assistance and encouragement the work would never have been undertaken.

Marie C. Lyle 


\section{CONTENTS}

PAGES

$1-3$

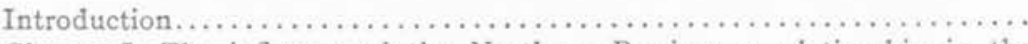

Chapter I. The influence of the Northern Passion: a relationship in the

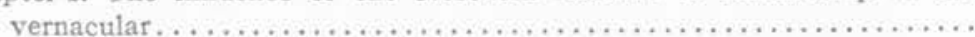

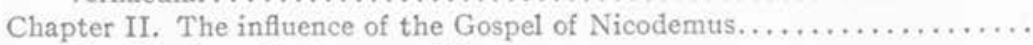

The Northern Septenar revision, ...........................

The old theory of a York parent cycle untenable...................

Separation of the York and Towneley cycles......................

Chapter III. The interrelation of the York and Towneley metres...........

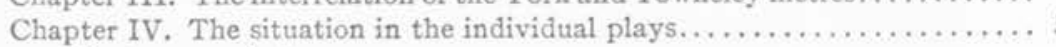

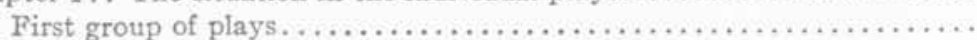

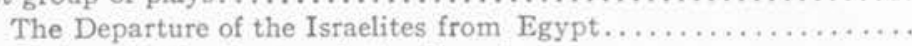

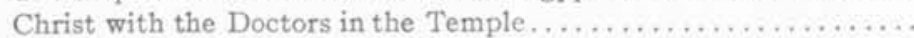

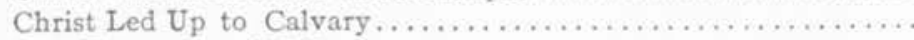

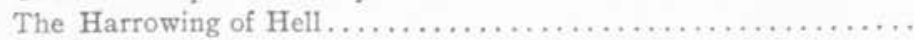

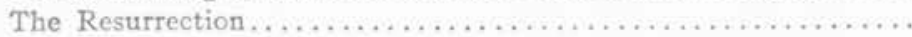

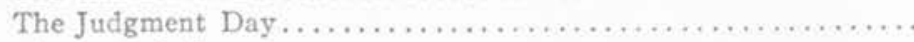

Second group of plays. . . . . . . . . . . . . . . . . . . . . . . . . . . . .

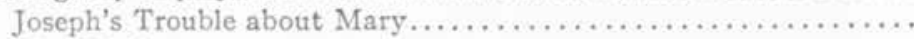

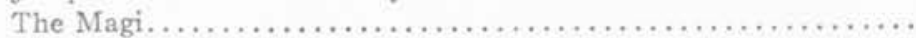

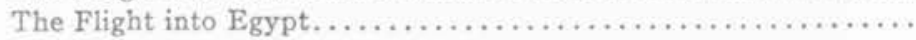

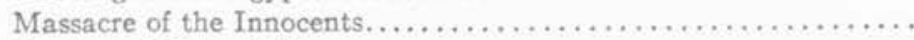

The Incredulity of Thomas $\ldots \ldots \ldots \ldots \ldots \ldots \ldots \ldots \ldots \ldots \ldots \ldots$

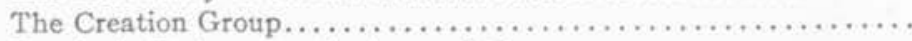

Prophetic Prologue to the Annunciation.....................

The Shepherds......................................

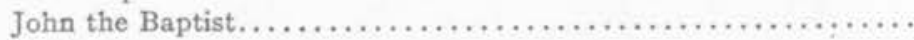

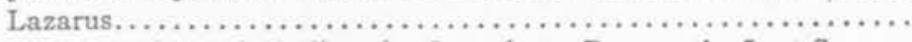

The Conspiracy, including the Conspiracy Proper, the Last Supper,

the Agony and Betrayal . . . . . . . . . . . . . . . . . . . . . . . . . . .

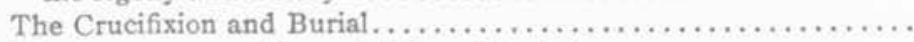

The Appearance of Jesus to Mary Magdalene................

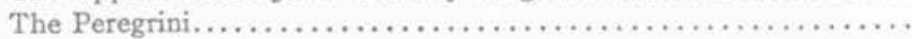

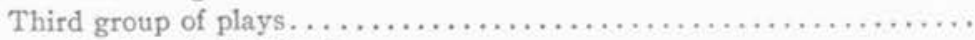

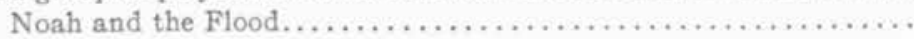

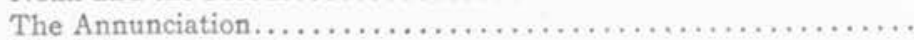

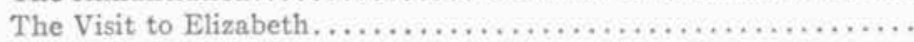

The Examination before Caiaphas........................

The Ascension. . . . . . . . . . . . . . . . . . . . . . . . . . . . . .

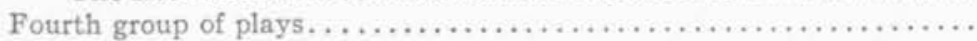

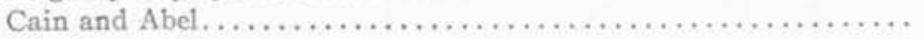

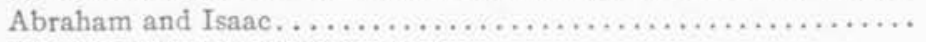

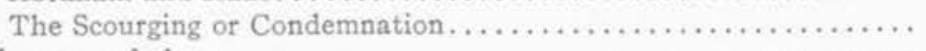

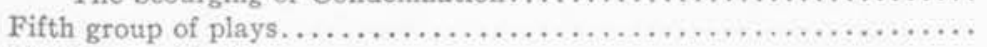

Sixth group of plays......................................... $98-100$

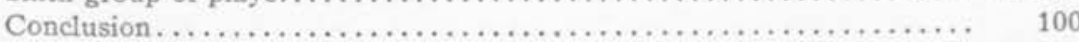

Development of the Towneley cycle.........................100-101

Chapter V. The probable date of separation..................... 102-8

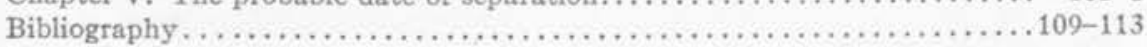

$4-29$

$30-46$

$30-45$

$45-46$

46

$47-51$

$53-54$

53

54-86 


\section{THE ORIGINAL IDENTITY OF THE YORK AND TOWNELEY CYCLES}

\section{INTRODUCTION}

The extent and the nature of the relationship between the York and Towneley cycles have been the subject of repeated investigation. Miss Lucy Toulmin Smith, the editor of the York cycle, ${ }^{1}$ called attention to five Towneley plays which, except for slight additions, gaps, or modifications, agree verbally with York plays. Further parallels between the texts of the two cycles were soon discovered. An identical stanza spoken by the Angel in York XVII (strophe 27) and Towneley XIV (strophe 100) was observed by Joseph Hall. ${ }^{2}$ Also, Dr. Herttrich ${ }^{3}$ noted that the greater part of the York play, Christ Led Up to Calvary (XXXIV), was present in Towneley (XXII), and that the Flight into Egypt (Y Pl. XVIII and T $\mathrm{Pl}$. XV) contained certain similarities in phraseology. In endeavoring to account for the presence of identical plays, or portions of plays, in the two cycles, each of these scholars proposed a different theory: (1) according to Miss Smith, Towneley borrowed the plays from York; ${ }^{4}$ (2) Hall preferred to believe that York borrowed the plays from Towneley; ${ }^{5}$ (3) Herttrich argued that the plays in question were derived from a common source. ${ }^{6}$

The problem of the relationship between the two cycles was further complicated by Professor Hohlfeld's discovery of the presence of slighter similarities in eight other plays. ${ }^{7}$ Discarding as insufficient the evidence produced for the theory of a common source, and regarding the borrowing on the part of York as unlikely, he concluded that the Towneley author must have been familiar with the York plays, and that he borrowed certain plays outright, constructed others from a memory of York plays, and wrote still others independently of any York influence. Those plays which he regarded as imitations are: the Annunciation, the Offering of the

1 Lucy Toulmin Smith. The York Mystery Plays (1885). The plays noted by Miss Smith were York XI, XX, XXXVII, XXXVIII, XLVIII and Towneley VIII, XVIII, XXV, XXVI, XXX (part).

${ }^{1}$ Joseph Hall, Eng. Stud. (1886) 9:448. In the play of the Resurrection, one of the identical plays. he notes that the similarity begins earlier than Miss Smith (oD, cit, 397) had noticed.

20. Herttrich, Studien zu den York Plays (1886) 3-6.

T Miss Smith (op. cit. intro. xlvi), accepting the theory of the Surtees Sociefy editor of the Toteneley Mysteries (pref. $\mathbf{x}$ ) that the Towneley cycle was a collection of plays drawn from different sources. suggested that the plays in question were borrowed from York by Towneley.

I Mr. Hall (op. cil. 449), accepting Skeat's dictum (Joseph of Arimathea, pref. x) that "the law of progress in alliterative poetry is from lines cast in a loose mould to lines cast in a strict one," concluded that the York plays in their present shape are later than the corresponding Towneley texts.

- Herttrich, op. cif. On the basis of a detailed comparison of the identical plays, Dr. Herttrich concluded that the grammar of the insertions, omissions, and variations was such that neither cycle could have borrowed from the other, but that each was independently based upon a common original, of which perhaps the York version, with its greater metrical regularity and fulness in detail, was nearer the original.

${ }^{2}$ Hohlfeld. Die altenglischen Kollektivmysterien Anglia 11:219 ff. 
Magi, the Flight into Egypt, Herod the Great, the Conspiracy, the Buffeting, the Scourging, and the Crucifixion. ${ }^{8}$ In the Prologue to the Annunciation, Professor Davidson ${ }^{9}$ found a closer resemblance than that pointed out by Professor Hohlfeld. For this play, as well as for the Magi and the Flight into Egypt, Professor Gayley ${ }^{10}$ considered the theory of imitation probable. Such plays as Abraham and Isaac, John the Baptist, and the Peregrini, he believed, were based upon "early alternatives of York plays, later discarded."

The probability that later independent revisions of certain plays took place in each cycle after the period of contact has been suggested in different studies. Professor Davidson, having established by means of rhyme scheme tests a common authorship for the Northern Septenar strophes of the Towneley Conspiracio and the Northern Septenar plays of the York cycle, concluded that the Towneley play had been borrowed from York and that the later modification of the same strophe in the corresponding York play was an indication of a later revision based upon the play now extant in the Towneley cycle. ${ }^{11}$ Mr. Pollard ${ }^{12}$ hazarded a similar guess for the plays of the Peregrini and the Suspencio Iude, two plays which occur in another York metre, the "Burns" measure ${ }^{13}$ of the Resurrection. According to this assumption, the York plays represent revisions of the Towneley plays just mentioned. The minor changes discernible in the so-called identical plays are generally regarded as later modifications made by Wakefield ${ }^{14}$ playwrights, ${ }^{15}$ although some of the changes may have taken place in the York cycle. Moreover, the additions by the so-called Wakefield author in the play of the Last Judgment are decisive evidence of later revisions in the Towneley cycle. ${ }^{16}$

The most recent theory is that proposed by Professor Cady. ${ }^{17}$ Observing the general structural similarities which underlie the York and Towneley plays of the Nativity, Passion, and Resurrection groups, he endeavors to account for them by assuming that the two cycles developed from a common liturgical source. This theory, however, fails to supply an adequate

Towneley plays X, XIV, XV, XVI, XX, XXI, XXII, and XXIII.

'Charles Davidson, Studies in the English Mystery Plays 157.

u Davidson, op, cit. 144 .

II A. W. Potlard, The 144.

a Saintsbury, History of

1 M. H. Peacock. The Wrish Prosody. 1:204 ff.

u Smith, oD. cil. intro, xlvi;

is A. W. Pollard, op. cil, intro.

hand, (The Towneley Couplets and Oat Gayley, op. cit. 177 present this view. Cady, on the other in Towneley, Mod, Phil. 10:599) maintains that Journ. Eng. Ger. Phil. 10:572 ff. and The Passion Group York borrowings. Mrs. Grace Prank. Rethat the work of the so-called Wakefield author preceded the presents evidence for the older vrank, Revisions in the English Mystery Plays, Mod. Phil. 15:181 ff. ${ }^{17} \mathrm{Cady}$. The Liturgical Basis of the? 
explanation for the existing relationship, ${ }^{18}$ since it confines itself to those portions of the cycle to which the liturgy of the Church might be expected to afford parallels, ${ }^{19}$ and takes no account of other similarities which are certainly due to vernacular sources. Moreover, it fails entirely to account for the remarkable parallels presented by the identical plays. These plays, as well as certain similarities in other plays, indicate a common source not only in liturgical plays but also in the vernacular.

Thus, the relation between the two cycles must be explained by a theory which takes into consideration, not only all the existing similarities, but also all the dissimilarities. In. the case of the similarities, we have, as already noted, a practical identity of certain plays, a verbal identity of isolated passages in certain other plays, and a structural resemblance, without the presence of verbal agreement, in still other plays. The earlier theories advanced, those by Miss Smith, Mr. Hall, and Dr. Herttrich, were based, in general, upon the presence of identical plays in the two cycles; the later theories, those by Hohlfeld, Davidson, Pollard, Gayley, and $\mathrm{Cady}$, assumed that the relationship which determined the presence of identical plays in the two cycles was different from that which determined the presence of less striking similarities in other plays. Although, in general, they admitted the possibility of independent revisions in the two cycles after the period of contact, they failed to consider the possibility that all existing similarities may be explained by one hypothesis, and that the dissimilarities were the result of later independent revisions. The presence of identical plays may, indeed, indicate the relationship originally existing in the two cycles. It, therefore, seems to me that the York and Towneley cycles were one and the same up to a certain period in the vernacular stage; that this identity of plays represents the parent-cycle stage; and that this parent cycle, established separately at York and Wakefield (?), underwent revisions at both places, the revisions in one cycle being independent, presumably, of those in the other.

That the similarities in the corresponding plays of the two cycles differ in degree and kind is due to the fact that certain plays underwent more extended revisions than others. Six distinct groups of plays may be distinguished: (1) plays which are practically identical, (2) plays showing a close similarity in structure and phraseology extending to the retention of common rhymes, (3) plays showing a close similarity in structure, but with not so extensive a similarity in phraseology, (4) plays showing a similarity in structure but with no similarity in phraseology, (5) plays showing little similarity in structural outline and no agreement in phraseology, (6) plays present in one cycle but not in the other.

\footnotetext{
is Mrs. Frank, op. cit. p. 186, n. 2, points out that Professor Cady takes no account of differences in earlier York plays as described in Burton's 1415 list.

"Chambers, The Medieval Stage 2:ch. xviii-xxii.
} 


\section{CHAPTER I}

\section{THE INFLUENCE OF THE NORTHERN PASSION: A RELATION- SHIP IN THE VERNACULAR}

The most decisive evidence pointing to a relationship between York and Towneley in the vernacular is supplied by the metrical narrative known as the Northern Passion. ${ }^{1}$ The immediate source of the two cycles is available only in the case of the Passion group: namely, the Northern Passion and the Gospel of Nicodemus, ${ }^{2}$ and in this group of plays, the vernacular sources, not liturgical, adequately account for the existing similarities.

The influence of the Northern Passion upon certain of the York and Towneley plays has been noted by Miss Foster, ${ }^{3}$ but the comparison may be extended further. The parallels already pointed out occur in six of the twelve plays making up the York Passion group proper. ${ }^{4}$ Of the six remaining plays, the Conspiracy and Agony, as recorded in the accompanying chart, and the Trial before Herod ${ }^{5}$ show in a slighter degree the influence of the Northern Passion. This leaves but three plays of the York Passion group unaffected by it, and two of these, the First Trial before Pilate and the Condemnation, show the influence of the other vernacular source, the Gospel of Nicodemus. ${ }^{6}$ In Towneley, in addition to the Conspiracio, ${ }^{7}$ a definite use of the Northern Passion, as shown in the accompanying chart, appears in all of the Passion plays except that of the Talents.

The influence of the Northern Passion upon York and Towneley is shown in the following chart.

Prances A. Foster. The Northern Passion EETS 145 and 147.

${ }^{2}$ W. H. Hulme, Middle Bnglish Harrowing of Hell and Gospel of Nicodemus EETS (Ex. Ser.) 100 ;
W. A. Craigie. The Gospel of Nicodemu 147. The part which the Gospel of Nicodemus and the York Mystery Plays Furnivall Birthday Book 52 ff. be presented below, ch. II.

Postet, op. cit. ERTS 14 .

EETS 147:81 ff.

The plays extending from the Entry into Jerusalem up to and through the Death and Burial are
included in the Passion group proper. In Play Xxot, the Trial before

occur: cf. NP II. 976a and Y $11,134-35$; NP verbal and structural similarities to the Northern Passion NP 11. 1005-6b and Y 11. 394, 392.

I See belorv, ch. II, pp. 31.32 for.

source of the Entry, the other $31-32$ for the influence of the Gospel of Nicodemus upon these two plays. The been discovered.

In an earlier article (Mod. Lang. Notes 24:169), Miss Foster believed the influence of the Northern
Pastion apparent in Towneley plays XXI. XXIII, later study (EETS 147:86 fl.), she says nothing concernin, and XXVI, as well as XX, the Conspiracio, but in a 
CHART SHOWING THE RELATIONSHIP BETWEEN THE PASSION GROUPS OF YORK AND TOWNELEY AND THE NORTHERN PASSION

* indicates the incidents treated similarly in York, Towneley, and the Northern Passion.

* indicates incidents merely suggested by the Northern Passion, but developed further in York and Towneley by means of similar details.

f indicates the incidents treated similarly in York and Towneley, but not found in the Northern Passion.

THE NORTHERN PASSION ${ }^{8}$

un

*(2) The council of the Jews.

*(a) The Jews fear the growing popularity of Jesus.

his vertues sprede swythe wyde fferre in pe lande at hym Envie And said he ferden alle with folye, (11. 13-16, Add. B. M. 31,042)

The passages quoted are taken from the Harleian MS. 4196 unless otherwise specified. See Northern Passion EETS 145 .

$\left|\frac{\text { TOWNELEY }}{\text { XX. THE CONSPIRACY }}\right|$

†(1) Introductory boastful specch by Pilate. $t$ (a) Pilate boasts of being a great ruler.

Ye wote not wel, I weyn/

what wat is commen to the towne,

So comly cled and cleyn/

a rewler of great renowne.

(11. 10-12)

†(b) Caiaphas praises Pilate.

. . prynce of mekyll price, that preuyd is withoutten pere. (11. 54-55)

+(2) Same

* $f$ (a) Same

Ther is a lurdan ledyr/ . . .

A bowtt;

A prophete is he prasyd,

And great vnright has rasyd.

And yit $\dot{I}$ stand in fere/

so wyde he wyrkys vertus. (II. 31-39)

\begin{tabular}{cc} 
YORK \\
\hline XXVI. THE CONSPIRACY \\
\hline
\end{tabular}

$\dagger$ (1) Same

†(a) Same

Vndir pe ryallest roye of rente and renowne,

Now am I regent of rewle pis region in reste,

To me betaught is be tent pis towre

begon towne. (II. 1.5)

†(b) Pilate praises himself.

I am a perelous prince,

To proue wher I peere.

*(2) Same

${ }^{*}+$ (a) Same

. per is a ranke swayne

Whos rule is nozt right,

For thurgh his romour in bis reme

Hath rasyede mekill reke. (11. 33-34) 
THE NORTHERN PASSION

*(3) Charges brought against Jesus.

*(a) That he will destroy their laws. If we lat him pus furth gane,

Al be folk sal trow him in. (11. 26-27)

\section{TOWNELEY}

*(3) Same. Against "that fature fals ihesus." (1. 37)

*(a) Same

Towchyng that tratoure strang,

that makys this beleyf,

ffor if he may thus furth gang,

It will ouer greatly grefe. (11. 62-65)

$f(b)$ That he claims to be the son of God.

Emangys the folke has he the name that he is godys son, and none els,

And his self says the same

that his fader in heuen dwelles. (11. 134-37)

f(c) That he breaks the Sabbath.

f(d) That he claims to be king, for which Pilate threatens punishment.

* . well more is ther; he callys hym self heuens kyng. (11. 120-21)

(Pil.) . that shall he aby

with bytter baylls. . . . . .

(11. 124-25)

t(e) The soldiers bid Pilate be more temperate.

Sir pylate, mefe you now no mare, bot mese youre hart and mend youre mode. (11. 150-51)

$f(f)$ Suggestion that Jesus may be mad. (1. 155)

\section{YORK}

(3) Same. Against "pat false faytor." (1. 47)

*(a) Same

\section{†(b) Same}

For he kennes folke for to call Grete god son, pus greues vs pat gome, And sais pat he sittande be schall, In high hetien, for pere is his hall.

$$
\text { (11. 51-54) }
$$

$\dagger$ (c) Same

$\dagger$ (d) Same

H. and also pat caytiff He callis hym oure kyng.

(Pil.) And if so be, pat borde to bayll will hym bryng. (11. 115-17)

$\dagger$ (e) Pilate bids the accusers be more temperate.

His maistreys schulde moue $30 u$,

Youre mode for to amende. (1. 63)

$\dagger(f)$ Same (1. 91) 
*(4) The Jews order Jesus' arrest after the Feast. (Entry into Jerusalem occurs here; omitted in Towneley and occurs in

York before the Conspiracy.)

*(5) Judas' reason for selling Jesus.

*(a) Supper at Simon the Leper's.

pai come vntill a gude man's hows, pat named was symon leprows; And als pai at baire supere sat, (11. 99-101)

*(b) Mary Magdalene anoints Jesus' feet.

Doune scho fell and wesche his fete With pe teres pat scho grete, And sepin scho dried pam with hir hare,

And for hir sins scho murned sare. Ane oynement with hir scho broght, pat was of precius thinges wroght: And parwith scho enoynted him,

Als scho enoynt him, heued \& fete, And honord him hir bales to bete, pe oynement went obout full wide In pe hows on ilka side. (11. 107-20)

*(c) The anger of Judas at the anointing.

pat pis vnement was euill despende, And said bat it suld haue bene salde Thre hundreth penis to haue talde. (p. 20,11. *14-*16)

And pat might haue done mekill gude To be gifen to pouer men foode, (11. 129-30)

†(4) Pilate orders Jesus' arrest.

* $\dagger$ (5) Judas explains his reason for selling Jesus.

* $f$ (a) Judas tells of the supper at Simon the Leper's.

In symon house with hym sat I. (1. 250)

* $\dagger$ (b) Judas tells of Mary Magdalene's anointment of Jesus' feet.

She weshyd hym with hir terys weytt. and sen dryed hym with hir hare

ffor synnes that she had wroght

she wepyd sore always

And an oyntment she broght,

that precyus was to prayse.

This fare oyntment, hir bale to beytt, apon his hede she put it thare, That it ran all abowte his feytt, The house was full of odowre sweytt. (11. 254-64)

*t(c) Judas tells about his anger, etc.

I sayd it was worthy to sell

thre hundreth pens in oure present, ffor to parte poore men emell; bot will ye se wherby I ment?

The tent parte, truly to tell,

to take it to me was myne intent; ffor of the tresure that to vs fell.
${ }^{*} \dagger$ (4) Same as T

${ }^{*} \dagger(5)$ Same as $\mathrm{T}$

*†(a) Same as T

For at oure soper as we satte,

With Symond luprus ... (11. 128-29)

${ }^{*} \dagger$ (b) Same as T

That baynly to his bare feet.

\section{* $\dagger$ (c) Same as T}

pat same oynement, I saide, Might same haue bene solde For siluer penys in a sowme Thre hundereth and fyue

Haue ben departid to poure men As playne pite wolde.

But for pe poore ne bare parte 


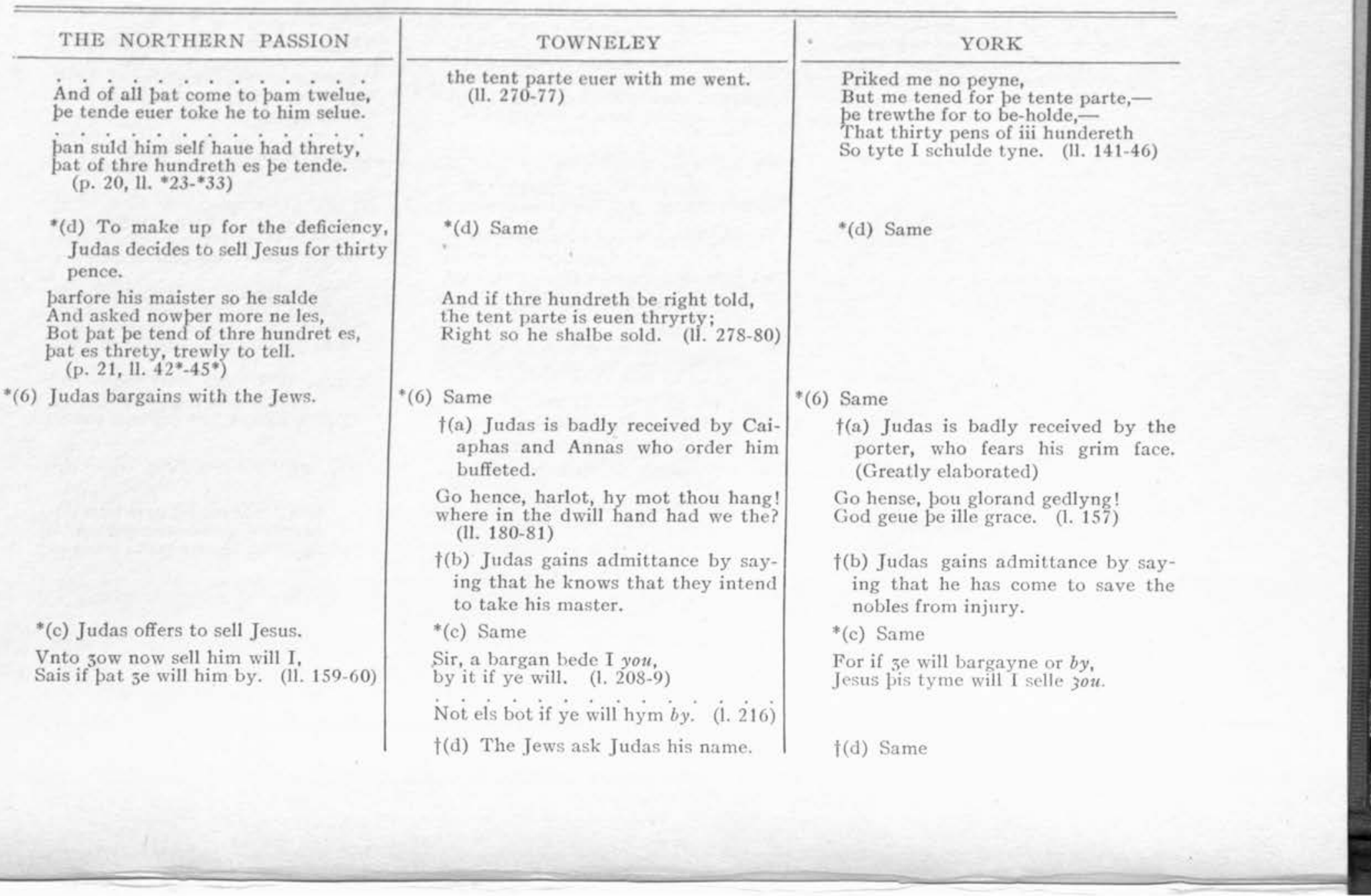


*(e) Judas asks thirty pence for Jesus. ffor threty penis plainly talde, And nowper for les ne for mare. (p. $19,11.4^{*}-6^{*}$ )

*(7) Jesus and the disciples sit down to the Last Supper.

Ihesus bad pam all sit doune And to his biding war pai bowne. (11. $204 a, b)$

*(8) Judas and the sop.

(F) 9 Iudas saughe pay sittene alle agayne Ihesu he gane downe falle pat he moughte with hym ete. (Add., 11. 209-11)

- (F) indicates parallel pasrages called attention to by Miss Foster, ibid. EETS 147:84 ff.
What is thi name? do tell in hy, Iudas scarioth, so hight I. (11. 210-13) (Pilate ans.)

Sir, thou art welcom witterly! (1.214)

*(e) Same

ffor thretty pennys truly told,

or els may not that bargan be.

(II. 240-41)

f(f) Judas will sell Jesus for the sum he made him lose.

(6) occurs here.

$t(g)$ The Jews praise Judas.

$t$ (h) Judas receives the money and tells the Jews how they may best take Jesus,

$f(i)$ The Jews gloat over the bargain.

$f(j)$ Pilate sends the soldiers to capture Jesus.

*(7) Same

Sir, youre mett is redy bowne, will ye wesh and syt donone?

$$
\text { (II. } 346-47 \text { ) }
$$

(8) Same

(F) Iudas, what menys thou?

No thyng, lord, bot ett with you. (II. $352-53$ )
What hytist bou?

Judas scariott. (1. 225)

(Pilate ans.)

bou art a juste mane.

*(e) Same

Sir thirtipens and plete, no more bane.

$$
\text { (1. 229) }
$$

$\dagger(\mathrm{g})$ Same

f(f) The Jews curse Judas.

$\dagger(h)$ Same

†(i) Same

†(j) Same

XXVII. THE LAST SUPPER

*(7) Same

(8) Omitted; it may have occurred in the gap. 


\section{THE NORTHERN PASSION}

*(9) Jesus foretells his betrayal, each of the disciples asking if it be he.

With tresun sall I be bitrayd,

And ilkone by pam self serely Said pusgat: "lord, es it oght I bat swilk treson has puruaid?" (11. $249 \mathrm{a}-59$ )

*(10) Footwashing scene.

*(a) Jesus calls for water.

$\mathrm{Vp}$ he rase right fra be burde And toke a clath with milde chere And a bacyn with water clere. (11. 330-32)

*(b) Jesus kneels at Peter's feet. And on his knese down gan he fall And said pat he wald wass his fete. (11. 334-36)

*(c) Peter objects.

\section{TOWNELEY}

\section{(9) Same}

for oone of you shall [me] betray.

Pet.) lord, I shall neuer the betray;

Dere master, is it oght I?

(John) Master, is oght I he then?

(And.) Master, am oght I that shrew?

(Sim.) Master, then is oght i?

(Phil.) Is it oght $\dot{I}$ that shuld do that dede?

(Thad.) Was it oght I that hight thadee?

Nay certys, god forbeyd

that euer shuld we do that deyd.

(11. 355-77)

*(10) Same

*(a) Same

Take vp this clothe and let vs go, ffor we haue othere thyngys at do. (11. 382-83) Commys furth, both oone and othere If I be master I will be brothere. If I be master

*(b) Same

Sit all downe, and here and sees,

ffor I shall wesh youre feet on knees. (11. 384-85)

*(c) Same

\section{YORK}

*(9) Gap. The end of the scene, however, is given.

(John) Lord, who schall do pat doulfull dede? (1.99)

*(10) Same; occurred between (7) and (8). *(a) Same

Do vs haue watir here in haste. Maistir, it is all redy here, And here a towell clene to taste. Commes forthe with me, all in feere. (11. $40-43$ )

*(b) Same

Settis youre feete fourth, late see,

They schall be wasshen sone.

(11. $45-46$ )

*(c) Same 
Peter answerd and said, "nay,

pat will I noght by none kins way,

It fals noght maister vnto me

Slike seruise forto tak of pe."

(11. 336-40)

*(d) Jesus replies.

(F) pan said ihesus: "bot I do pis, pou gettes no part with me in blis. (11. $341-42$ )

*(e) Peter finally agrees.

F) pat blis, lord, lat vs noght forga,

Wasche heuid and hend lord pray we be. (11. 344-45)

*(f) Jesus says that Peter does not realize the significance of the scene.

I haue done 3 e ne wate whatt. (Add. 1. 356)

* $(\mathrm{g})$ Jesus tells the significance of the scene.

Maister and lord now $3 \mathrm{e}$ me call

And wele ze say for I am so.

And 3 it I haue kneled 3 ow vnto

And wasschen 30 wre fete all on raw,

So pat 3 e sall ensample knaw

Meke and bowsum forto be,

Ilkone to oper with hert. fre,

And serue ilkone vntil ober.

(11. 358-63)

*(d) Same

(F) Bot I the wesh, thou mon mys

parte with me in heuens blys.

(11. $392-93$ )

*(e) Same

(F) Nay, lord, or I that forgo,

wesh heede, handys, and feytt also. (11. 394-95)

*(f) Same

why I do it thou wote not yit, peter, herafter shall thou wytt. (11. $388-89$ )

*(g) Same

ye call me master and lord, by name; ye say full wele, for so I am;

Sen 1, both lord and master, to you wold knele

to wesh youre fete, so must ye wele.

Ensaumpyll haue I gyffen you to.

(11. 404-9)
A! lorde, with pi leue, of pee

pat dede schall nozt be done.

I schall neuere make my nembres mete,

Of my souerayne seruice to see.

$$
\text { (11, 47-50) }
$$

*(d) Same

Petir, bott if pou latte me wasshe bi fecte,

pot getis no parte in blisse with me (11. 51-52)

*(e) Same

A! mercy, lorde and maistir swete, Owte of pat blisse pat I noght be, Wasshe on my lorde to all be wete, Both hede and hande, beseke I pe. (11. 53-56)

\section{*(f) Same}

Petir, pou wotiste no 3 t 3 it

What pis werke will bemene.

Here aftir schall pou witte.

$$
\text { (11. 57-59) }
$$

*(g) Same

zoure lorde and maistir ze me call, And so I am, all welthe to welde, Here haue I knelid vnto 3 ou all, To wasshe youre feete as 3 e have feled. Ensaumple of me take ze achall,

Tobo. . . .

buxsome

Ilkone for to bede othir belde. (11. 61-68) 


\section{THE NORTHERN PASSION}

*(11) Jesus tells the disciples that they will forsake him; he gives the shepherd and flock illustration.

And pis day sall ye be adred,

When I sall be fra 3 ow led;

3e schallene faste fro me fle,

And sum of 3 ow forsake me.

ffor prophettes in paire bukes write

And sais, "pe hirdman sall I smyte

And al be folk oway sal fle."

pis es all ment by zow and me,

I am pe hird and 3 e my schepe,

the hirde, whane he gose his waye

his bestis spredene swythe wyde.

(Harl. and Add. 11. 377-85)

*(12) The foretelling of Peter's denial.

*(a) Peter assures Jesus that he will not forsake him.

. . sertes, pat sall noght be, Lord, we sall neuer fra be fle.

I sall wende with pe whare pou gase

And wende to presoun for bi sake,

And with be will I suffer dede.

(11. $395-400$ )

*(b) Jesus foretells the denial.

And, peter, pus I say to be

pat, or pe kok haue krawin thrise,

pat my name saltou deny

And fast forsake my cumpany.

And witnes take with tales vntrew

\begin{tabular}{|c|c|}
\hline TOWNELEY & YORK \\
\hline *(11) Same & *(11) Same \\
\hline $\begin{array}{l}\text { Or that this nyght be gone, } \\
\text { Alone will ye leyf me; } \\
\text { ffor in this nyght ilkon } \\
\text { ye shall fro me fle. } \\
\text { flor when the hyrd is smeten, } \\
\text { the shepe shall fle away; }\end{array}$ & $\begin{array}{l}\text { All bat in worlde is wretyn of me } \\
\text { Shall be fulfilled, } \\
\text { I am pe herde, pe schepe are } 3 \text {. } \\
\text { And whane pe herde schall harmes haue, } \\
\text { The flokke schall be full fayne to flee. } \\
\text { (11. } 142-46 \text { ) }\end{array}$ \\
\hline
\end{tabular}

the shepe shall fle away;

the prophetys thus can say.

(11. $416-23$ )

(11. 142-46)

*(12) Same

*(a) Same

If all, master, forsake the, shall I neuer fro the fle.

(11. 378-79)

*(b) Same

ffor sothe, peter, I say to the,

That or the cok haue crowen twyse, thou shall deny me tymes thre.

$$
\text { (11. 426-29) }
$$


pat pou neuer bifore me knew. (11. 408-10f)

(F) or pe cokke thrise sall crawe

pou sall forsake me in a thrawe.

(Camb. Gg. 5.31, 11. 409-10)

*(13) Jesus' sermon according to Luke.

*(a) Jesus asks the disciples to come with him.

*(14) Jesus and the disciples on Mt. Olivet.

(a) Jesus' agony.

Myne flesche es alle in grete quakynge My hert has dout \& dredes ill,

ffor angers bat er cumand me till.

(Add. and Harl. 11. 442-42b)

*(b) Jesus asks the disciples to pray.

Wakys and prays to heuyn king. pat 3 he fall in no fandyng.

(Camb. Gg. 5.31, 11. 473-74)

*(c) Jesus' first prayer.

"ffader," he said, "if it may be, Lat pis paines pas fra me.

ffor I am redy loud and still,
(F) Peter, thou shall thryse apon a thraw

fiorsake me, or the cok craw.

(11. $380-81$ )

•(13) Jesus' sermon according to Matthew *(a) Same

Ryse vp, peter, and go with me, and folowe me withoutten stryfe; Iudas wakys, and slepys not he; he commys to betray me here belyfe. (11. $652-55$ )

-(14) Same

*(a) Same

*(b) Same

Say youre prayers here by-neth, that ye fall in no fowdyng.

(11. 496-97)

*(c) Same

ffader, let this great payn be styll, And pas away fro me

Bot not, fader, at my wyll,

bot thyn fulfyllyd be. (11. 500-3)
*(13) Same as Northern Passion.

-(a) Same

Butt ryse now vppe, for we will goo,

By pis owre enemyes ordand are. (ii. $180-81$ )

XXVIII. AGONY, CAPTURE, BETRAYAL

\section{*(14) Same}

*(a) Same

My flesshe dyderis \& daris for doute of my dede,

Myne enemyes will newly be neghand full nere. (11. 2-3)

*(b) Same

And lokis nowe prestely 3 e pray

To my fadir, pat 3 e falle in no fandyng. (II. 11-12)

Beeis wakand and prayes faste all in

fore, $\begin{aligned} & \text { fodir, pat ze falle in no fand- } \\ & \text { To }\end{aligned}$ ing. (11. 78-79)

*(c) Same

And if it possible be

This payne myght I ouer-passe.

Euen at thyne awne will, 


\section{THE NORTHERN PASSION}

In worde and werk to wirk pi will. (II. 449-54)

*(d) Jesus, finding the disciples asleep. awakens them.

*(e) Jesus prays a second time.

*(f) Jesus, again finding the disciples asleep, leaves without awakening them.

*(g) Jesus prays a third time.

(Angel appeared at the first prayer).

$\overrightarrow{+}$

*(h) Jesus, returning to the disciples a third time, awakens them, telling them that his time has come.

Slepes and restes now hardily, ffor pe tyme es cumand nere

bat ze sall suffer sorows sere

And all if $3 \mathrm{e}$ haue sleped wele,

(F) Iudas has sleped neuer a dele. (11. 496-98)

Ryse vppe all for my sake

I se paime come pat wyll me take.

(Camb. Gg. 5.31, 11. 501-2)

*(15) Judas in council with the Jews.

TOWNELEY

*(d) Same

*(e) Same

*(f) Same

*(g) Same

* $\dagger$ The Trinity appears to comfort Jesus.

†Jesus' mission to man is told.

To tyme that childe to deth were dight. (1. 544)

*(h) Same

Slepe ye now and take youre rest! My tyme is nere command;

Awake a whyle, for he is next

that me shall gyf into synners hand, (11. 556-59)

(F) Iudas wakys, and slepys not he. (1. 654)

(F) Bot com furth, peter, and tary no langere:

lo, where thay com that will me take. (11. 658-59)

*(15) Same

\section{$\frac{\text { YORK }}{\text { Euermore both myldely and still. }}$

$$
\text { (11. 58-62) }
$$

*(d) Same

*(e) Same

*(f) Same

*(g) Same

* + An angel appears.

tSame

For dedis pat man done has

Thy dede schall be dight. (1. 117)

*(h) Same

*(15) Same 
*(a) The Jews wonder how it will be best to take Jesus.

And ordand by pam self allane

How pat he might best be tane.

(p. $51,11.3^{*}-4^{*}$ )

(b) Judas offers to lead the way.

. I sall zow lede

To find him wele with owten drede,

And when I haue broght 30 w him till,

pan may 3e wirk with him zowre will

-(c) Judas offers to kiss Jesus.

"Say vs how we sall him knaw,

for sum of va him neucr saw,

And if he be omang his men,

Say vs how we sall him ken.

(Jud.) ... "of him 3 e sall noght mis,

Takes pe man pat I sall kis.

(II. $11^{*}-18^{*}$ )

*(16) Preparation to seize Jesus.

*(a) The soldiers are equipped with swords.

pan pai come with ful grete rowte

And vmsett ihesus all obout.

With swerdes \& maces \& glaues gude.

(11. 513-15) *(a) Same

*(b) Same

(c) Judas wants the help of the soldiers.

*(d) Same

wherby, Iudas, shuld we hym knaw,

ffor som of $\mathrm{vs}$ hym neuer saw,

(Jud.) lay hand on hym that I shall kys. (11. 588-91)

*(16) Same

*(a) Same

Ordan ye knyghtys to weynd with me, Richly arayd in rewyll and rowtt;

So I have felyship me abowte *(a) Same

Sen bat we are of counsaille ilkone, That Jesus pat traytoure wer tane. (11. 156-57)

*(b) Same

(Cay.) For bou muste lede vs and lere vs.

(Iud.) Sirs, I schall wisse you be way Euen at youre awne will. (11. 171-73)

t(c) Same

*(d) Same

sis, Judas, but be what knowlache Shall we pat corse kenne?

(Jid.) Qwhat man som I kys,

pat corse schall ye kyll. (11. 176-79)

(16) Same

*(a) Same

bay are arrayed and armyed clere (1. 218) 


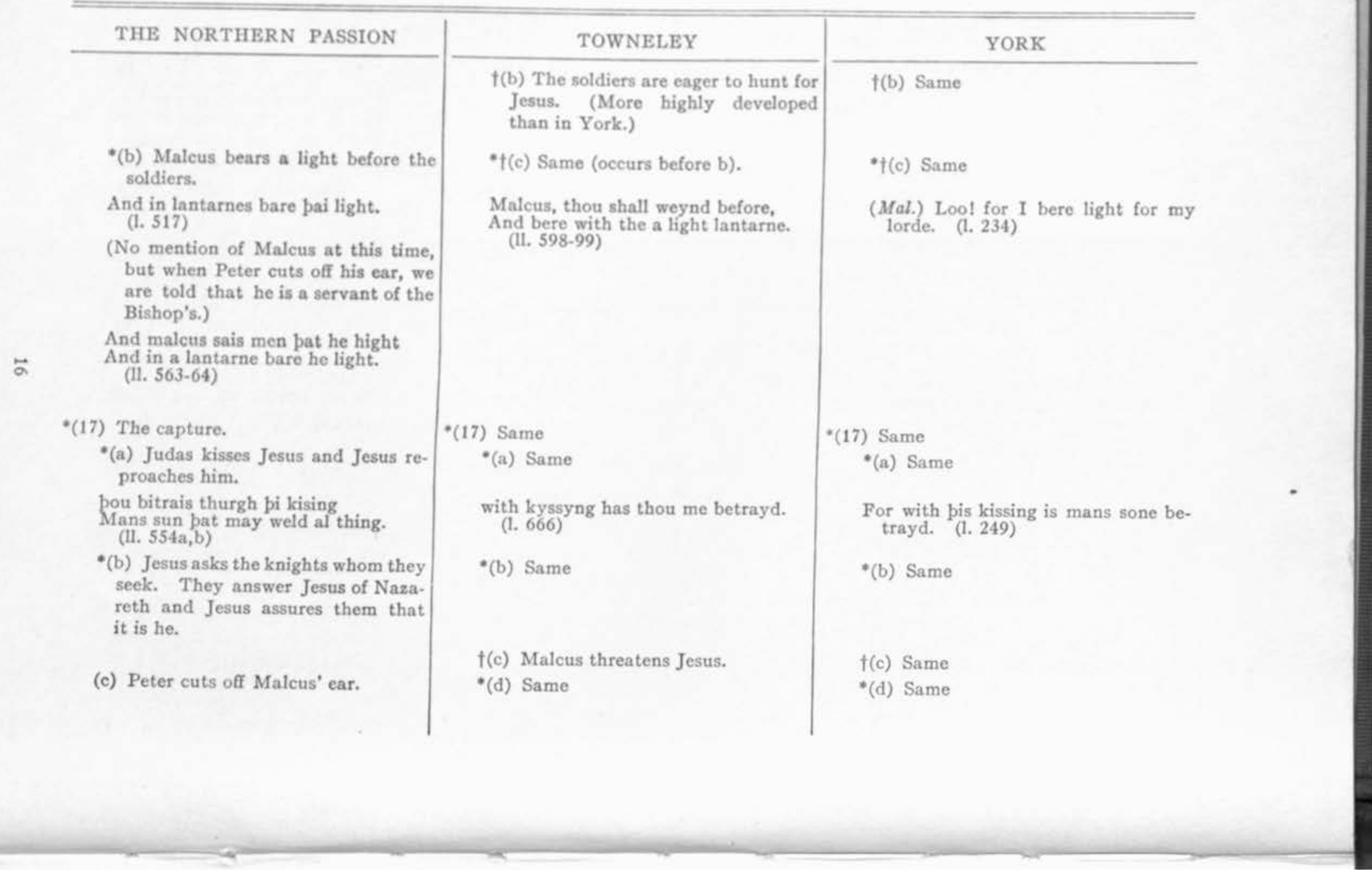


(F) And his right ere of he schare. (1. 561)

*(e) Jesus reproaches Peter.

"Put vp," he said, "pi swerd ogaine, ffor he that slase he sall be slane. And he pat smites with swerd, I wis Thurgh swerd he sall peris.

$$
\text { (II. 567-70) }
$$

*(f) Jesus heals the ear.

And toke pe ere pat was of schorn.

And helid it with his haly hand, He made it hale als it was are.

(11. $584-87$

*(i) Jestus is taken as a thief.

F) pan ihesus said to pam in fere, "Als a thef 3 e bind me here,

$$
\text { (1. 591-92) }
$$

ban bai come with ful grete rowte And vmsett ihesus all about.

(1. 513-14)

Tyll me 3 he do mykyll vnryght bus to fare wyth me by nyght. (Camb. Gg. 5.31, II. 593-94)

In zowre temple 3 ow bitwene Techand be law to ilka man:

Whi wald $3 \mathrm{c}$ noght tak me ban?

$$
\text { (II. 598-600) }
$$

*(j) Jesus is taken to Caiaphas.
(When Jesus heals the ear, he says)

(F) Take me thi ere that he of share. (1. 690)

-(e) Same

Put vp thi swerde and do no mys,

for he that smytys, he shalbe smyter. (11. 698-99)

-(f) Same

com heder, let me thi wounde se: Take me thi ere that he of share! In nomine patris hole pou be!

$(\mathrm{Mal}$.) Now am I hole as I was ere,

$\mathrm{My}$ hurt is neuer the wars. (11.689-93)

$t(g)$ Malcus is ungrateful.

$t$ (h) The soldiers are eager to seize Jesus.

*(i) Same

(F) ye knyghtys that be commen now here,

thus assemblyd in a rowte.

As I were thefe, or thefys fere,

with wepyns com ye me abowte;

Me thynk, for sothe, ye do full yll

thus for to seke me in the nyght. (11. 700-5)

* $f$ (j) Same -(e) Same

For-thy putte vppe pi swerde

Full goodely agayne. (1. 279)

*(f) Same

Come hedir to me sauely, And I schalle pe sayne,

Of thy hurtis be poti hole.

(Mal.) +. I hope pat I be hole.

(11. $283-87$ )

$\dagger(\mathrm{g})$ Malcus is grateful.

th) Same

*(i) Same

Euen like a theffe heneusly Hurle 3 e me here. (1. 294)

I taught you in youre tempill, Why take 3e me no 3 t banne? (1. 295)

* $f$ (j) Same 


\section{THE NORTHERN PASSION}

${ }^{*}(18)$ Jesus is led to Caiaphas.

*(19) The accusations.

*(a) That he claims to be able to tear down the temple and rebuild it in three days.

*(20) Caiaphas examines Jesus.

*(a) Jesus refuses to answer.

*(c) Caiaphas finally asks him if he is God's son, and is answered.

"I coniore pe thurgh god lifand pat pou me tell to vnderstand

\section{TOWNELEY}

Out of my handis shall thou not pas Out of my handis shall thou
ffor all the craft thou can

ffor all the craft thou can;
Till thou com to sir cayphas,

Saue the shall no man.

(11. 752-55)

\section{THE BUFFETING}

*(18) Same

f(a) The soldiers make remarks about the journey.

*(19) Same

*(a) Same

f(b) That he breaks the Sabbath.

t(c) That he cures the sick.

*(20) Same

ffor, certys, I my self shall/ make examynyng. (1. 128)

*(a) Same

$\dagger$ (b) The Jews are angry at Jesus silence and wish to beat him.

*(c) Same

\section{YORK}

We haue holde pis hauk in pi handis, Whe! zis, felawes, be my faith he is

Vnto sir Cayphas I wolde pat he past. (11. 298-300)

XXIX. EXAMINATION BEFORE CAIAPHAS

\section{*(18) Same}

f(a) Same

*(19) Same

*(a) Same

t(b) Same

$\dagger$ (c) Same

*(20) Same

For my selfe schall serche hym and here what he saies. (1. 275)

*(a) Same

$\dagger$ (b) Same

*(c) Same

I coniure be kyndely, and commaunde

be also,
By grete God pat is liffand and laste schall ay, 
If pou be god sun of heuyn." Thesus answerd with milde steuyn :

"pou sais pi self pat I am he,

And sertanly I say to be,

In heuyn blis men se me sall

With my fader pat weldes all.'

(11. 659-66a)

*(d) The Jews consider that no more witnesses are needed; that Jesus is worthy of death.

He said vnto pe iews all:

Wharto suld 3 e more witnes call?

He grantes omang vs all full euyn

And sais he es god sun of heuyn.

Sen he it grantes till vs ilkane.

Ober witnes nede ys nane;

And barfore sais, what es zowre rede?'
Say, art thou godys son of heuen. As thou art wonte for to neuen? (Jes.) So thou says by thy steuen And right so I am:

ffor after this shall thou se/

when that [I] do com downe

In brightnes on he

in clowdys from abone. (11. 249ff.)

*(d) Same

Thou art worthy to de! /. . . .

we nede no wytnes,

hys self says expres. (11. 256-60)

f(e) Since Caiaphas does not possess "temporal" power, they decide to send Jesus to Pilate for condemna tion.

Sich men of astate/shuld no men deme. (1. 291)

$f(f)$ Caiaphas orders the buffeting.

*(21) The buffeting.

*(a) Jesus is scorned and abused.
(21) Same

(a) Same

$\dagger$ (b) Jesus is set upon a stool as an indication that he is a fool. (Usually occurs in the Herod trial).
Yf bou be Criste, Goddis sonne, telle till vs two.

(Jes.) Sir, pou says it pi selffe, and sothly I saye,

pat I schall go to my fadir bat I come froo,

And dwelle with hym wynly in welthe all-way. (11. 292-97)

*(d) Same

Nowe nedis nowdir wittenesse ne counsaille to call,

But take his sawes as he saieth in be same stede,

$\mathrm{He}$ slaunderes pe godhed and greues vs all,

Wherfore he is wele worthy to be dede. (11. 302-5)

t(e) Same

(Annas to Caiaphas)

ze awe to deme noman. (1, 339)

t(f) Same

*(21) Same

*(a) Same

t(b) Same 


\section{THE NORTHERN PASSION}

"(b) Jesus' eyes are bound, and the soldiers, mocking, strike at him.

pai said pus: "tell vs, if pou wate,

Whilk of vs es pat pe smate;

If pou kan oght of prophecy,

Tell pe suth till vs in hy,

Rede whilk of vs smate pe now,

If pou will we on pe trow."

(11. $802 \mathrm{a}-4$ )

*(23) Jesus is led back to Pilate with Herod's message.

*(a) Pilate wishes to release Jesus.

*(b) Pilate and Jesus tell each other of their respective powers.

And als it es in my powere To lat pe pas and mak pe clere, (Jes.) Of all pi powere rek I noght, ffor power hastou none of me, Bot bat es granted vnto be,

\begin{tabular}{l} 
TOWNELEY \\
\hline *(c) Same \\
Sit vp and prophecy, \\
Bot make vs no ly. \\
who smote the last? \\
was it I? \\
he wote not, I traw. (11. 411-14)
\end{tabular}

f(d) The torturers lead Jesus back to Caiaphas who sends him to Pilate.

XXII. THE SCOURGING
$\begin{aligned} & f(22) \text { Introductory boastful speech by } \\ & \text { Pilate in his council chamber. }\end{aligned}$

\section{(23) Same}

*(a) Same

t(b) Accusation made that Jesus claims to be king.

*(c) Same

Thou knowes I haue powere

To excuse or to dampne here.

(Jes.) Sich powere has thou noght / to wyrk thi will thus with me,

Bot from my fader that is broght/

oone-fold god in persons thre.

(11. 113-17)

\section{YORK}

*(c) Same

f(d) Same

XXXIII. CONDEMNATION OF
JESUS

†(22) Same

*(23) Same

*(a) Same

†(b) Same 
pi might es gifen to be ful euyn fra my fader bat es in heuyn. (11. $1235-40 \mathrm{~b}$ )

*(c) Pilate offers to release Jesus.

*(d) The Jews ask that Barabas be set free and Jesus put to death.

Thesus sall be ded sertes, nay, Ihestus sall be ded pis day.

ffor ihesu sall on none wise pas.

(11. 1057-60b)

-(25) Accusation that Jesus claims to be king of the Jews.

ffor king of iews he gers him call;

pat semes als we suld be his thrall,

And, sir, pat gase noght wele obout,

To mak ys all his vnderlout.

(11. $1117-18 \mathrm{~b}$ )

*(26) Pilate says that he would release Jesus, if it were not for his "own folk." (1. 1123)

*(27) Pilate washes his hands as an indication that he is guiltless. *(d) Same

*(e) Same

Nay, nay, bot barabas!

And ihesus in this case

To deth ye dam this day. (11. 122-24)

$\dagger(24)$ Jesus is beaten and scourged.

\section{(25) Same}

he cals hym a kyng in euery place/

thus wold he ouer led

Oure people in his trace/

And oure lawes downe tred. (11. 199-200)

•(26) Same ("own lordyng")

*(27) Same
(24) Same; also mocked, crowned with thorns and dressed in purple.

*(25) Same

(Gap)

*(27) Because of the gap, only the latter part of the scene. 

se doghters of ierusalem

And witues out of bedleem,

Nomore now ze murn for me.

ffor no sorow se on me se;

Bot for zowre self wepe ze bis day

And for 3owre childer murn se may :

ffor be daies er cumand fast

bat all ioy sall be fra 30 w past;

Opon zowre faders sal ze cry

And on sowre moders and say in hy:

'ffaders, wharto war we born?

Wikked werdes er vs by forn

Moders, wharto war we wroght?

Moders, wharto war we wroght?

Better war vis hate bene noght.

Vnto be hillis pan sall ze say,

And vnto mountaynes in be way

Hilles, falles doune on vs in fere

And mowntaynes on pe same manere,

Doun opon vs fast 3 e fall

Out of bis care to couer ys all.

A And bus ban sall ze say sertayne:

"Blisced be be bodis bat er barayne.

bat in bis werld neter childer bare.

(II. $1531-48 \mathrm{e}$ )

-(37) Simon, the Cyrenian, is made to carry the cross, because Jesus is unabl. to bear it longer.

•(a) The Jews, noticing Jesus' weariness call upon Simon to help.

(F) And pis grete birbin pat he beres To gang with all mekill him deres. (ii. 1267-68)
Ye doghters of Ierusalem/

I byd you wepe nothyng for me.

Bot for youre self and youre barn temey behald 1 tell you securle.

Sore paynes ar ordand for this reme in dayes herafter for to be:

youre myrth to bayll it shall downe streme in euery place of this cyte.

Childer, certys, thay shall blys women baren that netier child bate,

And pappes that neuer gaf sowke, Iwys/ thus shall thare hartys for sorow be sare:

The montayns hy and thise greatt hyllys/ thay shall byd fall apon them thare,

ffor my bloode that sakles is

to shede and spyll thay will not spare. (II. $338-45$

135) The soldiers threaten the women and drive them away.

(Str. 42 identical with Y 19).

(36) The torturers hasten along with Jesus.

-(37) Same

-(a) Same

It nedys not hym to harll/

this cros dos hym greatt dere.

Bot yonder commys a carli)

shall help hym for to bere. (II. 358-59)
Doughteres of Jerusalem cytte,

Sees, and mournes no more for me.

But thynkes vppon this thyng:

For youre selfe mourne schall 3ee.

And for be sonnes pat borne schal be

Of yowe, bothe olde and yonge:

For such fare schall be-falle,

That $3^{\mathrm{e}}$ schall giffe blissyng

To barayne bodies all,

That no barnes forthe may brynge.

For certis ze schall sce suche a day.

That with sore sighyng schall se saye

Vnto be hillis on highte,

Falle on vs, mountaynes, and se may,

And couere vs fro pat felle affraye,

That on vs sone schall light. (II. 161-76)

$f(35)$ Same

(36) Same

-(37) Same

*(a) Same

(P) It nedis nozt harde to harle

Sen it dose hym slike dere.

se here comes a karle.

Shall helpe hym for to bere.

(11. $227-30$ ) 
THE NORTHERN PASSION

(F) A man es here omanges vs led pat wery es and all for bled,

And if pou will now for oure sake Of pis man pe rode tre take

And bere it furth whare it suld be. (II. 1563-71)

*(b) Although Simon remonstrates, he is forced to carry the cross.

Symon saw it was no bote Ogaynes so many forto mote. (II. $1581-82$ )

*(39) Jesus is nailed to the cross with tortures and jests.

Both his armis pai laid on brade Till bores pat pai by fore had made, And furth also pai laid his fete;

Bot to paire merkes was he noght mete, be bores war bored so fer fro

His armes might noght reche pam to,

If pe tone hand at pe bore ware,

(F) pat oper failed a fute and mare

On aibier side ${ }^{\circ}$.

Vntill bai might be pai kraw

be sins brast, pat was no wonder,

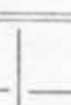

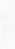

(T

\section{TOWNELEY}

( $\mathrm{T}$ str. 43 same as $\mathrm{Y}$ str. 23.)

lo here a lad that must be led

ffor his yll dedys to dy,

And he is bressed and all for bled,

That makys vs here thus stratly sted;

we pray the, sir, for-thi.

That thou will take this tre/

bere it to caluary. (11. 369-74)

*t(b) Same

(T strophes $45,46,47,48$ are identical with Y $26,27,28,29$.)

XXIII. THE CRUCIFIXION

$\dagger(38)$ The torturers display implements needed for the crucifixion.

Lo, here I haue a bande, (1. 65)

$o$, here a hamere and nales also.

*(39) Same

ffor to draw this arme on lengthe,

Tyll it com to the bore. (11. 120-21)

It wantys, tyll ich mans sight,

Othere half span and more. (11. 123-24)

\section{YORK}

(F) Loo, here a ladde pat muste be ledde For his ille dedis to dye;

And he is brosid and all for-bledde,

That makis vs here pus stille be stedde,

We pray pe, sir, for-thy,

That pou wilte take pis tree.

And bere it to Caluerye. (II. 242-50)

*t(b) Same

(F) It helpis nozt here to striue, Bere it behoues me nede. (11. 289-90)

XXXV. THE CRUCIFIXION

$\dagger(38)$ Same

And I haue gone for gere, goode speede,

Bothe hammeres and nayles large and lange. (11. 29-30)

*(39) Same

Hys lymmys on lenghe pan schalle I lede, And even vnto bore pame bringe. (11. 85-86)

(F) It failis a foote and more. (1. 107)

(F) Ther cordis haue evill encressed his paynes,

Or he wer tille pe booryngis brought. (11. 145-46)

zaa, assoundir are both synnous and veynis, On ilke a side, so haue we soughte.

(11. 147-48)

Latte noman wotte pat wondir, 
And lith fro lith all rafe in sunder,

F) Sunder went both sins and vaine,

To fele pat was a ferly paine. (11. 1605-20b)

*(a) The cross is lifted into place and dropped suddenly.

pe rode tre pai raised sone

And sett it hight vp on pe hill,

And vp pai lifted pe cros all

And sebin fast bai tele it fall

Into pe pit to eke his paynes,

bat sunder rafe both sins \& vaynes.

$$
\text { (11. } 1642-466 \text { ) }
$$

*(40) Jesus calls to the passers-by to see how he suffers.

*(a) Jesus has no place to rest his head, save on his shoulder-bone.

"ffox has den and fowles has nest Whare in pai may tak paire rest,

And I, pat am goddes sun so dere

Obouen all bestes \& fowles in fere

Place vnto me es nane leuid.

Whar on I may rest my heuid

Bot anly on my schulder bane,

Oper esment haue I nane.

(11. $1804 \mathrm{~g}-\mathrm{j}, 1637-40$ )

*(41) Jesus is mocked because of his claim

to kingship and boast to tear down the temple.

And als he said with in thre days Right ogayne he might it rayse.

(11. $1648 \mathrm{c}, \mathrm{d}$ )

\section{(a) Same}

yit let vs wyrke a whyle,

And noman now othere begyle

To it be broght on heght. (II. 206-8) hald even emangys vs all,

yee, and let it into the mortase fall.

$$
\text { (i1. } 218-19 \text { ) }
$$

\section{*(40) Same}

*(a) Same

Beestys, byrdys, all haue thay rest, when thay ar wo begon;

Bot godys son, that shuld be best, hase not where apon his hede to rest, Bot on his shuder bone. (11. 256-60)

\section{*(41) Same}

And yit he sayd he shuld it rase As well as it was, within thre dayes!

(1. 495-96)
A roope schall rugge hym doune, $\mathrm{Yf}$ all his synnous go a-sotundre. (11. 130-32)

*(a) Same

I badde we schulde hym hyng, On heghte pat men myght see. (11. 155-56)

And bere hym to 5 one hille on high. (1. 172)

And sette hym be bis mortas heere. And latte hym falle in alle at ones, For certis pat payne schall haue no pere.

Latte doune, so all his bones

Are a-soundre nowe on sidis seere. (11. 220-24)

*(40) Same

*(a) Same

For foxis per dennys haue bei, Birdis hase ther nestis to paye,

Bot pe sone of man this daye,

Hase nozt on his heed for to reste.

$$
\text { (P1. XXXVI, 11. 192-95) }
$$

XXXVI. MORTIFICATION AND BURIAL

(41) Same 


\section{THE NORTHERN PASSION}

*(42) The inscription on the cross and the displeasure of the Jews.

Grew ebrew and latyne

Was wretyn in pe parchemyne,

And on pis wise it was to mene:

"pis es ihesus nazarene,

pat king es of ilka iew."

(11. 1659-63)

\section{N}

*(43) Laments of Mary the mother and John.

•(44) Jesus commends Mary to John's care.

Woman, in pe stede of me

Behald to iohn, pi sun es he.

Man, bihald pi moder trew. (11. 1742a-44)

*(45) Jesus thirsts and is given vinegar and gall,

He said to bam: "me thristes sare."

$$
\text { (1. 1720) }
$$

(F) "Drink," pai said, "for no thing spare." (1. 1724a)

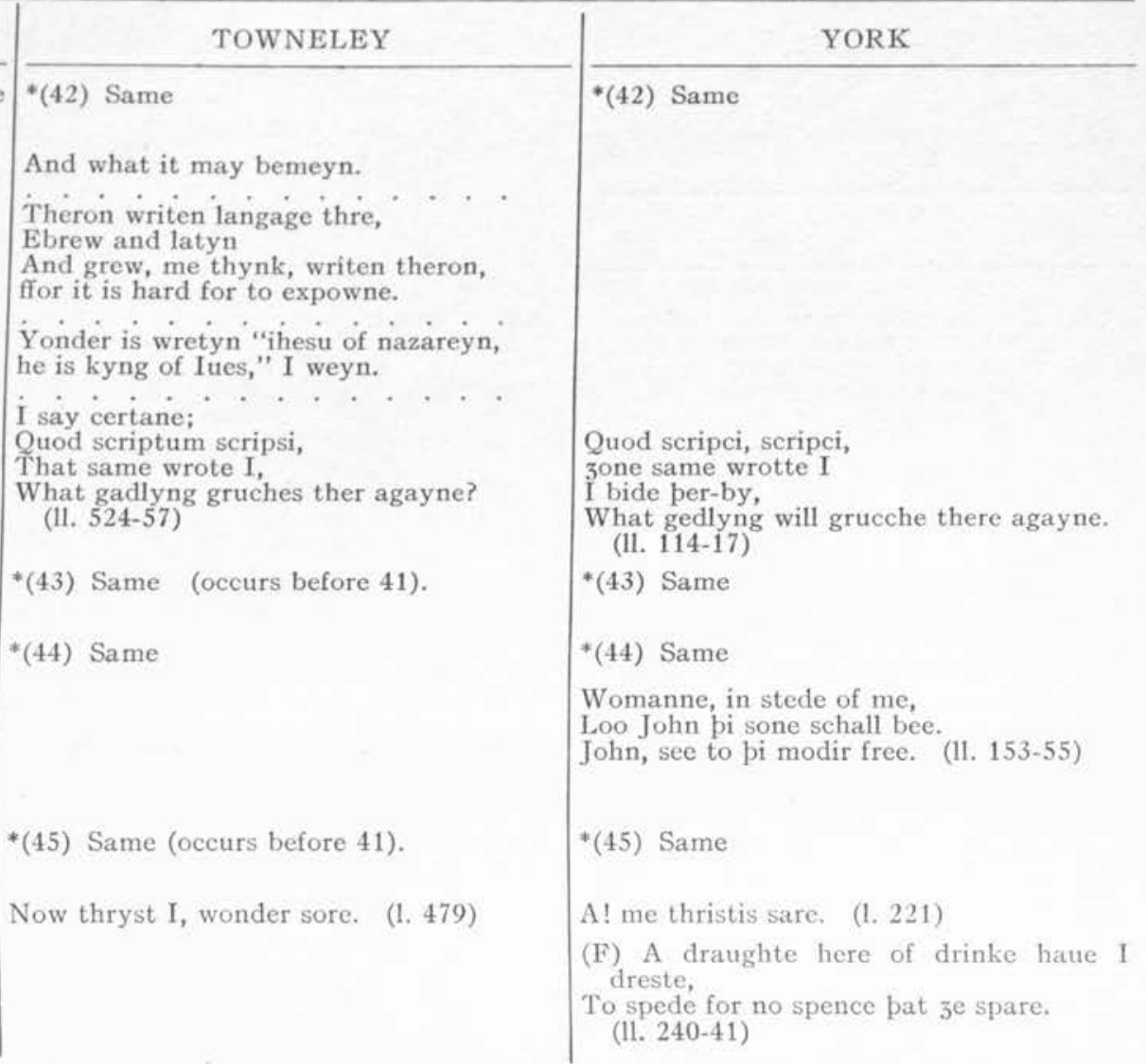


"(46) Jesus cries "Hely, hely," the Jews misunderstanding him.

Loud he cried, "Ely, Ely;"

And als, "lamazabathany;"

(F) "My lord, my god, my fader fre,

Whi hastou forsaken me?

pe iews pan pat stode biside

Herd how pat he Ely cryde. (11. 1787-94)

*(47) Jesus, forgiving them, commends his spirit to God.

ffader, I hate wroght pi will,

Done I haue efter bi rede,

Sakles here I suffer dede;

Bot, fader, forgif pam paire gilt

pat sakles here my blode has spilt.

ffor whi pai wate noght what pai do,

parfore pai tak no tent parto,

N ffor gif pam if pi willes be

pe dedes pai haue done to me.

ffader mine, bat all may mend,

I gif my gaste into pi hend. (II. 1500-1806)

*(48) The Longinus episode.

(F) Vnder pe cros pai gert him stand,

And gaf him a scharp spere in hand,

pe poynt bai set to ihesu side,

And bad him put fra him pat tide;

ban till his eghen he towched right,

And hastily so he had his sight.

(11. 1873-83)
(46) Same

hely, hely, lamazabatany!

My god, my god, wherfor and why

has thou forsakyn me?

how he can now on hely cry

apon his wyse? (11. 578-83)

+(47) Same

Thus haue thay dight me drerely,

Bot, fader, that syttys in trone,

forgyf thou them this gylt,

I pray to the this boyn,

Thay wote not what thay doyn,

Nor whom thay hate thus spylt.

(11. 287-94)

Now is my passyon broght tyll ende!

fader of heuen, into thyn hende.

I betake my saull! (11. 590-92)

*(48) Same
*(46) Same

Heloy! heloy!

(F) My God, my God, full frec,

Lamazabatanye,

Whar-to forsoke bou me,

Harke, Hecly! now harde I hym crye. (11. 213-27)

*(47) Same

pi wille haue I wrought in lis wonc,

pus doulffully to dede have bei done, Por-giffe bame be grace bat is goode,

bai ne wote nozt what it was.

My fadir, here my bone,

For nowe all thyng is done. (II. 252-58)

(48) Same

F) bis spere, 10o, haue halde in thy hande.

To fesu pou rake fourthe I rede,

And sted noust but stiffely bou stande

In Jesu side

Schoffe it pis tyde.

O! Maker vnmade, full of myght,

pat sodenly has lente me my sight.

(11. 292-302) 


\section{THE NORTHERN PASSION}

*(49) Joseph of Arimathea begs for Jesus' body and buries it.

And how ihesu was done to dede

Wrangwisly with wikked rede. (11. $1846 \mathrm{e}, \mathrm{f})$

"Sir," he said, "now pray I be,

"Sir," he said, "now pray I
Ihesu body grante pou me.

Ihesus body grant I pe,

Bot I will wit pat he ded be. (II. 1853-54)

(11. 1849-50) (11. 1853-54)

(49) Same

TOWNELEY

(49) Same

To se my master dede:

Thus wykydly as he is shent,

Thrugh fals Iues red.

Weicom, Ioseph, myght thou be

What so thou askys I graunte it the.

I graunte well if he ded be,

Syr pylat, god the saue!

Graunte me that I craue

Graunte me the body

(ii. $615-40)$
YORK

\section{*(49) Same}

To be I praye,

Giffe me in hye

Jesu bodye. (11. 335-37) 
In the preceding comparative analysis, three different groups of similarities may be distinguished between the Passion plays of the York and Towneley cycles: (1) those which are based primarily upon the Northern Passion; (2) those, which merely suggested by the Northern Passion narrative, are developed further in both cycles by the use of similar details; (3) those which are not found in the Northern Passion. Groups (1) and (2) include the incidents which were certainly fundamental in the making up of the Passion plays. They form the basis for the chief incidents connected with the Conspiracy, the Last Supper, the Agony and Betrayal, the Examination before Caiaphas, the Bearing of the Cross, the Crucifixion, Death, and Burial. The similarities in these two groups, then, are due to the use of a vernacular source, and can not be regarded as evidence pointing to a common liturgical source. ${ }^{10}$ Nor does it seem probable that the similarities belonging to the third group are of liturgical origin. They seem rather to be embellishments used by the playwright for dramatic purposes; in many cases, they are merely the additions which a dramatic presentation of the subject-matter demanded.

It is possible that the York and Towneley Passion groups may have had a common liturgical source, as suggested by Professor Cady, ${ }^{11}$ but all traces of it, supposing one to have existed, have been completely obliterated by material derived from the Northern Passion. The similarities existing between the corresponding York and Towneley plays of the Passion group can not, then, be explained by the theory of a common liturgical source, but must be ascribed, in large part, to the use of a vernacular source, that of the Northern Passion.

Were the similarities between the Passion plays of York and Towneley confined to the first and second groups, it would seem that these plays might have been derived independently from a common source, the Northern Passion. But the similarities included in the third group, those which have no basis in the Northern Passion, preclude this possibility. Such similarities indicate a contact between the two cycles, which obviously occurred after the influence of the Northern Passion. The most striking evidence for this view is seen in the events connected with the bearing of the cross to Calvary. The wording of the scene is practically identical in both cycles, although the text of the Northern Passion, while forming the basis for the play, does not provide for the close verbal agreement. The existence of such similarities seems rather to point to a parent cycle, from which the extant versions of the York and Towneley plays were derived. ${ }^{12}$

\footnotetext{
$1^{\circ}$ Cady. The Towneley Nativity and Resurrection Groups PMLA, 24:419 ff.; The Passion Group in Towneley Mod. Phil. 10:587 ff.

"Cady, ibid. Mod. Phil. 10:587 ff.

12 Whether or not the parent cycle included all of the Northern Passion incidents now present in the extant versions of both cycles, it is impossible to determine. It seems probable that the York cycle, because its use of the Northern Passion is more extensive than is that of the Towneley cycle, made a second and more extended use of it, perhaps when some of the plays were revised in the Northern Septenar metre. See below, ch. II. p. $30 \mathrm{ft}$.
} 
CHAPTER II

\section{THE INFLUENCE OF THE GOSPEL OF NICODEMUS}

\section{The Northern Septenar Revision}

The fundamental source of the Passion plays in the York cycle, as has been shown in the preceding chapter, was the Northern Passion. But one may recognize also in several of these plays the direct influence of another vernacular text, the Gospel of Nicodemus. This influence manifests itself not only in the appropriation of material but also in the adoption in several plays of its characteristic stanza, the "Northern Septenar." The dependence of the York plays upon the text of the Gospel of Nicodemus was first noted by Mr. Craigie; their indebtedness in the matter of metrical form was suggested by Professor Hulme in his edition of this Middle English poem. ${ }^{2}$

Unlike the Northern Passion, the Gospel of Nicodemus, as I shall endeavor to show, did not supply the fundamental source for the York plays dealing with the Passion but was used merely for elaboration and expansion. Although it forms the basis of the Harrowing of Hell and two of the trial scenes before Pilate, ${ }^{3}$ it could not have been fundamental in the formation of the Passion group, because it deals only with the incidents connected with the Trial and Condemnation of Jesus before Pilate, of his Crucifixion, Death, and Burial, of his Harrowing of Hell, and of his Resurrection. The York Passion group, on the other hand, begins with the Entry into Jerusalem and includes the events connected with the Bargaining and Selling of Jesus, the Last Supper, the Agony and Betrayal, the Examination before Caiaphas, Peter's Denial, the Trial before Herod, the two Trials before Pilate, the Scourging and Mocking of Jesus, the Bearing of the Cross, the Crucifixion, Death, and Burial. All of these events, however, as well as the Harrowing of Hell and the Resurection are treated by the Northern Passion, ${ }^{4}$ the influence of which is seen in all the plays beginning with the Conspiracy and up to and including the Resurrection, with the exception of the Harrowing of Hell and two of the Trial scenes before Pilate. Moreover, the events which are connected with but one of the trials in the Gospel of Nicodemus, that of the Condemnation of Jesus, are dispersed in York and incorporated into three of the trials,

1 Craigie, The Gospel of Nicodemus and the York Mystery Plays Furnivall Miscellany 52-61.

2 Hulme. The Middle English Harrowing of Hell and the Gospel of Nicodemus EETSES 100 :intro. sviit.

I Craigie, loc. cil.; see also below, p. 31, n. 5.

- Frances A. Foster, The Northern Passion EETS 145 and 147, and above, ch. I. 
the Examination before Caiaphas, the First Trial before Pilate, and the Condemmation by Pilate. ${ }^{5}$

Such a situation seems to indicate that additional material from the Gospel of Nicodemus was incorporated into the York cycle in order to elaborate the simpler trial scenes originally based upon the Northern Passion. This theory is borne out by a comparison with the description given the plays in the 1415 Burton list. ${ }^{6}$ Of the five plays which contain additions from the Gospel of Nicodemus, four differ from the description given them by Burton. The plays as described by him correspond to material derived from the Northern Passion, but they contain no mention of any material derived from the Gospel of Nicodemus. ${ }^{7}$

The extant version of Play XXX, the First Triol before Pilate, contains the following incidents: (1) the comic love scene between Pilate and his wife, (2) the beadle's objection to their behavior, (3) Pilate's preparations for sleep, (4) the appearance of the devil to Percula and the sending of the messenger to Pilate with the news of the dream, (5) the bringing of Jesus to Pilate, (6) the beadle's worshipping of Jesus as he enters the hall, ( 7 ) the beadle's account of the honor accorded Jesus on his entry into Jerusalem, ( 8 ) the accusations brought against Jesus, and (9) Pilate's sending Jesus to Herod when he learns that he is from Galilee. In the description given the play by the Burton list, ${ }^{8}$ only the eighth incident, as mentioned above, with the possible inclusion also of the fifth and the ninth, are provided for. It is significant that the Northern Passion deals only with these three incidents and since the influence of the Gospel of Nicodemus is to be found in the fourth, sixth, and seventh incidents and in a number of the accusations in the eighth incident, it

Verbal agreements are found in the following passages: (1) Between $\mathrm{Y} P 1 . \mathrm{XXIX}$ and $\mathrm{G}$ of $\mathrm{N}: \mathrm{Y}$ II. 33.39 and $G$ of $N$ II. 39-44, Y II. $40-45$ and $G$ of N Add. 11. 29-38, Y 11, 50-54 and G of N II, 22-28, Y I. 57 and $\mathrm{G}$ of N 11. $47-48$ : (2) between Y P1. XXX and G of N: (C) Y 1, 177 and G of N 11. 197-98. Y L. 292

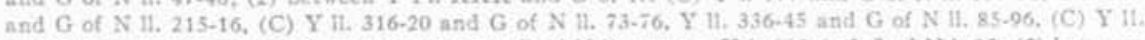
$346-50$ and $G$ of $N$ 11. 105-8. Y 11. 373-76 and $G$ of $X 11.113-16$. Y 1. 502 and $G$ of $N$ i. 25: (3) between $\mathrm{Y}$ P. XXXII and $\mathrm{G}$ of $\mathrm{X}: \mathrm{Y}$ 1. 91 and $\mathrm{G}$ of $\mathrm{N} 1.21$, (C) $\mathrm{Y}$ 11. $113-19$ and $\mathrm{G}$ of $\mathrm{X}$ 11. 13-20. (C) $\mathrm{Y}$ II. 88 , 134 and $G$ of $N$ It. 58-60, (C) Y II. $169-70$ and $G$ of $X 11.133-36$, (C) Y I1. 183-84 and G of $\mathrm{N} 11.139 .44$. (C) Y It. 243-52 and G of N 11. $161-64$, (C) Y Ti. 301.6 and G of X 11. 221-24. (C) Y 12. $315-19$ and G of N 11. 309-12. (C) $Y$ 11. $320-24$ and G of X II. 313-14. Y 11. 325-26 and G of N 11. 315-17.322-23. (C) refers to passages called attention to by Mr. Craigie, op. cit, Farnirdll Mriscellany 52.61.

The 1415 Burton list is printed by:

Drake, Eboracum app. xxx

Sharp, Cosentry Mysterier 135

Martiott, Colledion of Engirsh Miracle Plays xviii

Smith, York Mystery Plays intro. xix f.

Pollard, English Miracie Plays, Moralities, and Interludes.

(Por the sake of convenience. I shall refer only to Miss Smith's copy of the 1415 Burton list, hereafter.)

This would seem to indicate that the separation of the two cycles had taken place some time between 1415 and the entry into the Towneley manuscript, about the middie of the century. (See Pollard, os, cil. EETSES 71 intro. xxvit.) The discrepancy, in the two cycles, of the division into separate plays, however, makes it seem probable that the separation took place before 1415. (See below, ch. V. D. 107.) There in reason to believe that Burton's list represents the true situation as it existed in 1415 , only in regard to the separation of plays and their assignment to crafts, but that in many cases, the description given the characters and chief events refers to a situntion existing at an earlier period.

+ Miss Smith, fbid. intro. xxiv, in speaking of Play XXX, thought it "curious that no mention is made by Burton of dame Percula. Pilate's wife, nor of any of the personages in the first scenes, which must have been," she says, "prominent and popular."

I Burton list, Smith, ibid. intro, xix $f$. The description of the play, as found here, (p. xxiii) is: Jesus. Pilatus, Anna, Cayphas, dwo consiliarii et inijur I udei accusanies Jestum. 
seems possible to conclude that Burton's list describes an older play based only upon material from the Norihern Passion, and that the extant version of the York play represents a later play, showing a combination of events gained from both sources. ${ }^{3}$

Play XXXIII, entitled the Second Trial and Judgment before Pilate, the greater part of which is undoubtedly based upon the Gospel of Nicodemus, also differs from the description given it in Burton's list. The play, as we now have it, is made up of the following incidents: (1) Pilate's boasting of his power, (2) Jesus sent back by Herod with his message, (3) the accusations brought against Jesus, (4) the bowing of the standards when Jesus enters the hall and the anger of the Jews because of it, (5) the holding of the standards by the four strongest men in the realm, and in spite of their strength, the bowing again of the standards, (6) the deliverance of Barabbas and the Jews' demand for Jesus' condemnation, (7) the scourging, crowning, and mocking of Jesus, ( 8 ) the handwashing scene, (9) the condemnation. Burton ${ }^{10}$ describes the play in these words: Jesus, Pilatus, Cayphas, Annas, sex milites tenentes hastas cum vexillis, et alij quathor ducentes Jesum ab Herode petentes Baraban dimitti et Jesum crucifigi, et ibidem ligantes et flagellantes eum, ponentes coronam spineam super caput eius; tres milites mittentes sortem super vestem Jesu. The absence of the incident of the throwing of dice for the clothing of Jesus in the extant play is evidence in itself that Burton described a different play. It is impossible to decide whether Burton's reference to the six soldiers carrying spears and ensigns provides for the incident of the bowing of the standards or not, but because of the detail with which the incidents of this play are described by Burton, it probably does not. It is likely that the later introduction of this incident crowded out the incident of the throwing of dice, since, in the register, the latter incident has been divided and contracted to a few lines at the end of Plays XXXIV and XXXV. Moreover, the description as offered by Burton seems to refer to a play much simpler in detail and one which follows the Northern Passion narrative more closely than the extant play which shows an extensive influence from the Gospel of Nicodemus.

The description which Burton gives of Play XXXVII, the Harrowing of Hell. does not correspond to the present play. He describes the play thus: Jesus spolians infernum, xij spiritus, [vj] boni et vj mali."1 Obviously, this description refers to another play, since there is no mention of spirits in the extant version. It seems difficult to believe that the patriarchs of the extant play, reciting their prophecies as they await the coming of Jesus, or the devils as they oppose his entrance, could be referred to as "spirits"; and for that matter, the number of patriarchs and devils does not correspond to the number required in the list. It seems probable, then, that the description given by Burton refers to an earlier play, differing to a marked degree from the extant play, the incidents and phraseology of which are largely drawn from the Gospel of Nicodemus.

The Resurrection, Play XXXVIII, as described by Burton, also seems to refer to a simpler play than that of the extant version. Jesus resurgens de sepulcro, quatuor milites armati, et tres Marie lamentantes. Pilatus, Cayphas, with the later addition of et Anna. Juvenis sedens ad sepulcrum indutus albo, loquens mulieribus ${ }^{12}$ is, in all probability, a description of the present play only in so far as it is based upon the Northern Passion. No mention is made by Burton of the Centurion's reproaches against the Jews, nor of his recital of the overcasting of the weather at the time of Jesus' death,

Incidents one, two, and three, having no basis in biblical or apocryphal narratives, are to be regarded possibly as an original invention on the part of the playwright.

10 See Burton list, Smith, ibid, intro. xxv.

" Smith, ibid, intro, xxvi.

12 Loc. cit. 
given so much prominence at the beginning of the extant play. This material is derived from the Gospel of Nicodemus and if it had been included in the earlier play, it seems likely that Burton would, at least, have included the name of the Centurion in the list of characters. Apparently, its omission is to be explained only upon the ground that the material from the Gospel of Nicodemus was not included in the cycle at the time of its formation.

Since the addition from the Gospel of Nicodemus in Play XXIX, the Examination before Caiphas and Peter's Denial, did not necessitate either the introduction of an extra character or of a new incident, it is impossible to determine whether the play, as described by Burton, refers to the extant version or to an earlier play. Burton's description is too meagre in detail to help much: Jesus, Anna, Cayphas, et iiijor Judei percucientes et colaphizantes Jesum; Petrus, mulier accusans Petrum, et Malchus. ${ }^{11}$ The play, as a whole, is based upon the Northern Passion, with the introduction of material from the Gospel of Nicodemus in the matter of additional accusations, ${ }^{14}$ thus showing a similar situation to that existing in the other plays.

As already noted, Professor Hulme suggested the influence of the Gospel of Nicodemus stanza upon the Northern Septenar metre in the York cycle. He pointed out similarities in metrical structure, in the rhyme order, ababababcded, and in the three beat measure of the four lines of the cauda. ${ }^{15}$ Such similarities, however, do not positively establish the probability of direct influence, but they may be regarded as contributory evidence in connection with numerous cases of common rhyme series. ${ }^{16}$ $\mathrm{I}$, therefore, submit the following common rhyme series:

(1) The analysis of the identical rhyme series appearing between Play XXXVII, the Harrowing of Hell, and the Gospel of Nicodemus: ${ }^{17}$

(a) The identical rhymes are:

$\mathrm{Y} 15$, (as) sente, tente, mente, wente; G of $\mathrm{N} 84$, sent, ment, went, (en)tent. Y 22, (e) mang, wrang; $\mathrm{G}$ of $\mathrm{N} 43$, (0) mang, wrang. $\mathrm{Y} 2$, haue, graue; $\mathrm{G}$ of $\mathrm{N} 69,88$, haue, grane. Y 2 , sone, done; $\mathrm{G}$ of $\mathrm{N} 37,1855,129$, sone, done. Y 24 , telle, helle; $\mathrm{G}$ of $\mathrm{N}$ 128 , tell, hell. Y 7 , saide, laide; G of $\mathrm{N} 40,63,93,124$, sayd, layd. Y 23 , mee, be; $\mathrm{G}$ of $\mathrm{N} 28$, me, be. $\mathrm{Y} 5$, vndirstande, lande, walkand, leuand; $\mathrm{G}$ of $\mathrm{N} 100$, land, understand, walkand, lyfand. Y 22, myght, right; G of N 115, 116, 142, ryght, myght. Y 8, 30 , myght, hight, sight, light; $\mathrm{G}$ of $\mathrm{N} 118$, myght, lyght, syght, hyght.

(b) The included rhymes are:

Y 1, trayne, agayne; G of N 16, ogayne, slayne, trayne, mayne. Y 9, paste, faste; $\mathrm{G}$ of $\mathrm{N} 65.19$ kast, fast, past, last. Y 16 , name, same; G of N 10, ${ }^{20}$ blame, same, schame, name. Y 9 , haue, saue; $\mathrm{G}$ of $\mathrm{N} 64,{ }^{21}$ saue, graue, haue, straue. Y 31 , trewe, knewe;

Is Smith, ibid, intro. xxiii.

14 Compare especially $\mathrm{G}$ of $\mathrm{N} 39-44$ and $\mathrm{Y} 33-40 ; \mathrm{G}$ of N Add. $29-35$ and $\mathrm{Y} 40-45 ; \mathrm{G}$ of N $25-29$ and Y $51-56$.

is Hulme, $p$, cif. EETSES 100 intro, xviii, finds that a slight difference exists in the measure of the first eight lines, the Nicodemus having four-stressed lines alternating with three-stressed ones, whereas each of the York lines contains four stresses. Such a difference, however, he considers of minor importance.

is Davidson, of, cit. 137 ff. establishes the probability of a common authorship for all of the York plays in the Northern Septenar.

17 The references in the case of both texts are to the strophe numbers.

18 (vn)done.

$19 \mathrm{Cf}$, also $\mathrm{G}$ of $\mathrm{N} 112$, fast, kast, past, last.

${ }^{20} \mathrm{Cf}$. also $\mathrm{G}$ of $\mathrm{N} 54$, name, schame, blame, same.

$2 \mathrm{Cf}$. also $\mathrm{G}$ of $\mathrm{N} 147$ Add., sauc, haue, graue, staue. 
$\mathrm{G}$ of $\mathrm{N} 7,22$ tret, Thesu, new, knew. Y 28, weste, feste; G of $\mathrm{N} 53$, best, threst, west, fest. Y 25, wende, ende; G of N 45 Add., frende, wende, fende, ende. Y 13,2328 , werre. ferre; $\mathrm{G}$ of $\mathrm{N} 142$, were, here, fere, nere. Y 27 , leere, heere; G of $\mathrm{N} 39$, lere, manere. here, here. Y 11, myght, fight; G of N 131, fyght, dyght, myght, ryght. Y 22, myght, right; $\mathrm{G}$ of $\mathrm{N} 5,24$ ryght, myght, syght, dyght. Y 2, haue, graue; G of N $60,{ }^{25}$ graue, haue, straue, craue. Y 7 , saide, laide; $\mathrm{G}$ of $\mathrm{N} 68,{ }^{26}$ affrayd, payd, layd, sayd. Y 21 , hidde, kidde; $\mathrm{G}$ of $\mathrm{N} 6,{ }^{27}$ byd, kyd, hyd, dyd. Y 33 , till, fulfille; $\mathrm{G}$ of $\mathrm{N} 123$, ill, tyll. skyll, fullfyll. Y 3 , ill, will; $\mathrm{G}$ of $\mathrm{N} 19,{ }^{23}$ styll, vntyll, will, ill. Y $18,(\mathrm{a})$ bide, tyde, $\mathrm{G}$ of $\mathrm{N} 52,29$ syde, hyde, tyde, byde. Y 31 , vs, bus; G of N 31,00 pus, Ihesus, vs, bus. $\mathrm{Y} 17$, more, sore; $\mathrm{G}$ of N 139 Add., sore, (eter) more, pore, lore.

(c) The proportions are:

The number of rhyme series in Play XXXVII is 140.

The number of rhyme series in $\mathrm{G}$ of $\mathrm{N}$ is 585 .

The number of agreeing rhyme series is $31 / 140$ of all in Play XXXVII or 22 per cent.

The number of rhyming words agreeing is 68 in 408 lines of Play XXXVII or 1 in 6 lines.

(2) The analysis of the identical rhyme series appearing between Play II, the Creation to the Fifth Day, and the Gospel of Nicodemus:

(a) The identical rhymes are:

Y 7, sone, done; G of N 37," 55,129 , sone, done. Y 14, sall, all; G of N 44, 134, all, sall.

(b) The included rhymes are:

$\mathrm{Y} 5$, be, se; G of N 19, at me, se, fre, be. Y 2, forsake, blake, take, wake, sclake, make; $\mathrm{G}$ of $\mathrm{N} 44$, slake, sake, make, lake; $\mathrm{G}$ of $\mathrm{N} 84$, make, forsake, wake, take. Y 4 , pay, day; G of $\mathrm{N} 47$, pray, day, pay, say. Y 14, sall, all; G of $\mathrm{N} 100$, sa (with) all, thrall, sall, bifall. Y 7 , sone, done; G of N 36,4 mon, son, trone, done. Y 13 , (for)thoght, brught, (vn) soght, noght, oght, wrothe; G of N 10, ss thoght, noght, broght, wroght; G of N 23 , broght, soght, noght, wroght. Y 1 , wroght, soght; $\mathrm{G}$ of $\mathrm{N} 23$, 30 broght, soght, noght, wroght. Y 7, might, bright, syght, wyght, right, dyght; G of N $5^{37}$ ryght, myght, syght, dyght; $\mathrm{G}$ of $\mathrm{N} 98$, myght, ryght, wight, syght. Y 6 , byde, wede, (on)brede, fede, sede, lede: G of $\mathrm{N} 9$, led, wed, fed, bred. Y 8 , assent, went, hent, firmament, sent, entent; $\mathrm{G}$ of $\mathrm{N} 129$, went, assent, hent, entent. Y 4 , mene, betwyne, sene, clene, wyne, bydene;

* Cf. also $\mathrm{G}$ of $\mathrm{N} 9$, (vn)tretwe, knets, hebrew, Inoghe.

stware instead of werre.

st Ct. also G of N 92, ryght, hyght, syght, myght; 98, mysht, ryght, wight, syght; 128, myght, wight. ryght, hyght; 149 Add., knyght, myght, nyght, right.

2 Cf. also G of N 64, saue, krase, have, straue; 147 Add, satse, hawe. gratue, statse.

s Cf. also G of N 77, sayd, layd, affrayd, payd; 145 Add., sayde, brayde, mayde, layde.

2 Cf. aiso $\mathrm{G}$ of $\mathrm{N} 120$, kyd, kyd, dyd, bityd.

s Cf. also G of N 26, vatyll, ill, will, skyll; 31, wyll, ill, skyll, paretyll 83, tyil, will, skyll, ill.

s Cf. also G of $\mathrm{N} 145$ Add., tyde, pride, bide, wyde.

20 Cf. also G of N 78. bus. 75 . Nichodemus, Ihesus.

n (vn) done. $\quad$ a $\mathrm{Cf}$. also $\mathrm{G}$ of $\mathrm{N} 50$, plente, he, be, se; 64 , me, tre, se, be; 68 , meneyhe, $5 e, b e$. Galile; 80 , me, be, se,
pete; 135 , we, preuete, se, be; 140 . bounte, se, parde, be.

a Cf. also $\mathrm{G}$ of $\mathrm{N}$ 114, all, bifall, sall, small; 132, all, sall, call, sall.

" Cf. a!so G of N 138, (als)sone, trone, done, sone.

s Ct. also G of N 48, soght, broght, wroght, thoght; 62, thoght, noght, broght, soght; 66, thoght, wroght. broght, noght; 81 , soght, noght, broght, wroght; 124 , soght, wroght, broght, thoght; 140 , broght, soght, noght, tloght. " Ct. also $\mathrm{G}$ of $\mathrm{N} 48$, soght, broght, soroght, thoght; 81, soght, noght, broght, wroght; 124, 50ght, wroght, broght, thoght.

17 Cf. also G of N 57, ryght, dyght, syght, myght. 


\section{(c) The proportions are:}

The number of rhyme series in Play II is 41 .

The number of rhyme series in $\mathrm{G}$ of $\mathrm{N}$ is 585 .

The number of agreeing rhyme series is $13 / 41$ of all in Play II or 31 per cent.

The number of rhyming words agreeing is 41 in 86 lines of Play II or 1 in 2 lines.

(3) The analysis of the identical rhyme series appearing between Play X, Abraham's Sacrifice of Isaac, and the Gospel of Nicodemus:

(a) The identical rhymes are:

$\mathrm{Y} 20$, saye, ay; G of $\mathrm{N} 68$, say, ay. Y 14, praye, daye; G of $\mathrm{N} 97$, pray, day. $\mathrm{Y} 16$, fayne, layne, slayne, agayne; G of $\mathrm{N} 20$, slayne, fayne, layn, ogayn. Y 23, sone, bone; $\mathrm{G}$ of $\mathrm{N} 60$, bone, sone. $\mathrm{Y} 6$, sone, done; $\mathrm{G}$ of $\mathrm{N} 37,355,129$, sone, done. $\mathrm{Y} 22$, woroght, thoght; G of N 146 Add., (be)thought, wrought. Y 19 , thoght, noght, soght, wroght; $\mathrm{G}$ of $\mathrm{N} 66$, thoght, wroght, soght, noght. Y 1, lyffe, wyffe; $\mathrm{G}$ of $\mathrm{N} 16,18 \mathrm{Add}$., wyfe, lyf. Y 23, till, will; G of N 12,14,40 tyll, will. Y 9, wille, fulfille, skille, (per)tille; $\mathrm{G}$ of $\mathrm{N} 93$, will, $t y l l$, skyll, fullfyll. Y 26 , dede, stede; $\mathrm{G}$ of $\mathrm{N} 27,62,112,136$, stede, dede. Y 2, tree, see, be, me; G of N 64, me, tre, se, be. Y 16, be, me; G of N 28, me, be.

(b) The included rhymes are:

$\mathrm{Y} 8$, we, me; G of $\mathrm{N} 89$, he, se, we, me. Y 16, be, me; G of N 19,41 me, se, fre, be. $\mathrm{Y} 9$, Asse, has; $\mathrm{G}$ of $\mathrm{N} 70$, was, pas, ass, has. $\mathrm{Y} 14$, proye, daye: $\mathrm{G}$ of $\mathrm{N} 47,42$ pray, day, pay, say. Y 20, saye, ay; $\mathrm{G}$ of $\mathrm{N} 55,43$ pray, ay, say, day. $\mathrm{Y} 27$, fayne, agayne; $\mathrm{G}$ of $\mathrm{N} 20,4$ slayne, fayne, layn, ogayn. Y 31, agayne, mayne; G of N 16, ogayne, slayne, trayne, mayne. Y 4 , panne, beganne; G of $\mathrm{N} 27,{ }^{45}$ man, pan, bigan, kan. Y 25 , stille, tyll; $\mathrm{G}$ of $\mathrm{N} 19,46$ styll, (vn) $t y l l$, will, ill. Y 5, ille, will; G of N 19,47 styll, vntyll, will, ill. Y 23 , till, will; G of N 19,48 styll, (vn)tyll, will, ill. Y 26, dede, stede; G of N 25,40 rede, dede, hatred, stede. Y 17 , fell, telle; G of $N 2,{ }^{00}$ Gamaliel, fell, spell, tell. $\mathrm{Y} 20$, dere, nere; $\mathrm{G}$ of $\mathrm{N} 63,51$ fere, nere, dere, here. $\mathrm{Y} 11$, $\mathrm{nnto}$, doo; $\mathrm{G}$ of $\mathrm{N} 35,10$, do, into, bro. Y 6 , sone, done; G of $\mathrm{N} 36,52 \mathrm{mon}$, son, trone, done. Y 22 , wroght, thoght; $\mathrm{G}$ of $\mathrm{N} 10,{ }^{53}$ thoght, noght, broght, wroght. Y 16, desire, fyre; G of $\mathrm{N} 121$, syre, fyre, Ire, desyre. Y 3 , dight, sight; G of N 5, th ryght, myght, syght, dyght. Y 21, nercy, dy; G of N 57, dy, sykerly, by, mercy. Y 1, lyffe, wyffe; G of N 99, wife, ryfe, dryue, lyfe. $\mathrm{Y} 2$, rywe, stryve; $\mathrm{G}$ of $\mathrm{N} 131$, olyue, stryue, dryue, ryue. $\mathrm{Y} 5$, stryie, life; $\mathrm{G}$ of $\mathrm{N} 122$, lyue, stryue, bilyue, dryue.

It (vn)done,

s (be)lyue.

40. (vn)tyll.

"C Cf. also G of N 30 , contre, be, me, degre; 80 , me, be, se, pete.

s: C?. also G of N 102, say, pray, ay, day.

s Cf. also G of N 102, say, pray, ay, day; 110, may, oway, say, ay; 111, say, verray, oway, ay; 114, ay, say, day, $a y$.

4 Cf. also $\mathrm{G}$ of $\mathrm{N} 95$, fayne, ogayne, frayne, sayne.

a Cf. aiso $\mathrm{G}$ of $\mathrm{N} 37$, pan, man, can, bygan; 59, pan, bigan, ryghtwisman, wan.

"Ct. also $\mathrm{G}$ of $\mathrm{N} 49$, styll, tyll, skyll, spyll.

"t C?. also G of N 26, vntyll, ill, will, skyll; 31, wyll, ill, skyll, baretyll; 83, tyll, will, skyll, ill.

" Cf, also G of N 26. (trn)tyll, ill, will, skyll; 31 wyll, ill, skyll, (bare)tyll; 88, tyll, will, skyll, ill: 93, will, tyll, skyll, fullifyll.

"s Cf. also G of N 93, rede, dede, stede, godhede; 133, rede, stede, ded, godhede; 143, kyarede, ded, stede, godhede.

st Cf. also G of $\mathrm{N} 98$, tell, (bi)fell, hell, (bi)fell; 117, tell, hell, fell, snell.

s $\mathrm{Cf}$. also $\mathrm{G}$ of $\mathrm{N} 124$, clere, dere, here, nere.

s Cf. also G of N 138. (als)sone, trone, done, sone.

n Cf. also $\mathrm{G}$ of $\mathrm{N} 48$, soght, broght, avroght, thoght; 66 , thoght, wroght, broght, noght; 124, soght, wroght, broght, thoght.

s Cf. also G of N 57, ryght, dyght, syght, myght; 60, syght, ryght, knyght, dyght. 


\section{(c) The proportions are:}

The number of rhyme series in Play $\mathrm{X}$ is 121 .

The number of rhyme series in $\mathrm{G}$ of $\mathrm{N}$ is 585 .

The number of agreeing rhyme series is $36 / 121$ of all in Play X or 30 per cent. lines.

The number of rhyming words agreeing is 80 in 380 lines of Play X or 1 in 5-

(4) The analysis of the identical rhyme series appearing between Play XI, the Pharaoh, and the Gospel of Nicodemus:

(a) The identical rhymes are:

$\mathrm{Y} 14$, wille, vntill; $\mathrm{G}$ of $\mathrm{N} 14$, vntyll, will. $\mathrm{Y} 18$, tent, sente, wente, mente; $\mathrm{G}$ of $\mathrm{N}$ 84 , sent, ment, went, (en)tent. Y 32 , drede, lede; G of N 111, drede, lede. Y 29 , be, tree, me, see; G of N 64, me, tre, se, be. Y 15,31,33, me, be; G of N 28, me, be. Y 24 , sene, mene; G of N 76, mene, sene. Y 15, name, blame, same, shame; G of N 54, name, schame, blame, same. Y 29 , last, past; G of N 106, last, past. Y 3, faste, laste; G of N 94 , last, fast. Y 7, awe, drawe, lawe, sawe; G of N 141, aw, law, draw, saw. Y 1, passe, hasse, was, asse; $\mathrm{G}$ of $\mathrm{N} 70$, was, pas, ass, has.

(b) The included rhymes are:

Y 8, syde, bide; G of N 52, syde, hyde, tyde, byde. Y 14, wille, vntill; G of N $19^{35}$ styll, ontyll, will, ill. Y 12 , will, per-till; G of $\mathrm{N} 31$, wyll, ill, skyll, paretyll. Y 11,31 , noght, brought; G of $\mathrm{N} 10$, sh thoght, noght, broght, wroght. Y 12 , netve, trewe; $\mathrm{G}$ of $\mathrm{N}$ 7 , trew, Ihesu, new, knew. Y 31 , wende, lende, fende, kende, shende, sende, frende, fende; $\mathrm{G}$ of $\mathrm{N} 43$, send, lend; $\mathrm{G}$ of $\mathrm{N} 138$, fend, wend. Y 34 , bede, drede, nede, dede; $\mathrm{G}$ of $\mathrm{N} 42,140$, dred, nede. Y 6 , sprede, rede, dede, drede; G of N 57 , dede, dred. Y $15,31,33$, me, be; $\mathrm{G}$ of $\mathrm{N} 19,58$ me, se, fre, be. Y 34 , see, wee; G of $\mathrm{N} 135$, we, preuete, se, be. $\mathrm{Y} 24$, sene, mene; $\mathrm{G}$ of $\mathrm{N} 11, \mathrm{~s}$ bene, mene, sene, bidene. Y 16 , dere, here; $\mathrm{G}$ of $\mathrm{N} 29,60$ here, were, dere, powere. Y 30 , saide, paied; $\mathrm{G}$ of $\mathrm{N} 68,61$ affrayd, payd, layd, sayd. $\mathrm{Y} 18$, sake, take; $\mathrm{G}$ of $\mathrm{N} 44,62$ slake, sake, make, take.

(c) The proportions are:

The number of rhyme series in Play XI is 133.

The number of rhyme series in $\mathrm{G}$ of $\mathrm{N}$ is 585 .

The number of agreeing rhyme series is $30 / 133$ of all in Play XI or 22 per cent. lines.

The number of rhyme words agreeing is 72 in 406 lines of Play XI or 1 in $5+$

(5) The analysis of the identical rhyme series appearing between Play XII, the Prophetic Prologue, and the Gospel of Nicodemus:

(a) The identical rhymes are:

$\mathrm{Y} 7$, vs, Jesus; G of $\mathrm{N} 70,118$, Ds, Ihesus. Y 3, thynge, sprynge; G of N 146 , spryng, thing. Y 8, Jewe, knewe, newe, hewe; G of N 4, Iew, new, knew, hew. Y 12 , manere, here; $\mathrm{G}$ of $\mathrm{N} 106$, manere, here. Y 10 , was, Judas, passe, has; $\mathrm{G}$ of $\mathrm{N} 24$, , (Cayphas), was, pas, has. Y 11 , mast, gast; G of $\mathrm{N} 56$, mast, gaste.

$1 \mathrm{Cf}$, also $\mathrm{G}$ of $\mathrm{N} 26$, twill, ill, will, skyll.

u Ct. also G of N 23, broght, soght, noght, wroght; 62, thoght, noght, broght, soght; 66 , thoght, wroght,

broght, noght; 81 , soght, noght, broght, wroght; 140 , broght, soght, noght, thoght.

" $\mathrm{Cl}$. also $\mathrm{G}$ of $\mathrm{N} 18$, Iew, new, trew, retr.

"Cf. also $\mathrm{G}$ of $\mathrm{N} 30$, contre, be, me, degre; $80 \mathrm{me}$, be, se, pete.

" Cl. also $\mathrm{G}$ of $\mathrm{N} 18$, sarizene, bydene, sene, mene; 92 , mene, sers

$10 \mathrm{Cf}$. also $\mathrm{G}$ of $\mathrm{N}$ 63. fere, nere, dere, here; 113, clere, here, Lucifere, dere; 124 , cler

nere, dere, here; 113 , clere, here, Lucifere, dere; 124 , clere, dere, here, nere.

scyd, layd, affrayd, payd.

6f. also G of N 86, spake, sake, make, take.

a Cf. also G of N 77, (Cayphas), has, was, (ouer) pas; 94, (Cayphas), has, pass, was. 


\section{(b) The included rhymes are:}

Y 7,vs, Jesus; G of N 31,64 pus, Ihesus, vs, bus. Y 7, morne, borne; G of N $30,{ }^{6 s}$ born, biforn, morn, lorn. Y 2, mankyn, syn; G of N 16, mankyn, syn, twyne, blyn. Y 1. lyght, hyght; G of N 118, myght, lyght, syght, hyght. Y 12, manere, here; G of N 39,66 lere, manere, here, here. Y 1, space, grace; G of N 134, grace, space, trace, lace. $\mathrm{Y} 6,9$, panne, manne; $\mathrm{G}$ of $\mathrm{N} 27,67$ man, pan, bigan, kan. Y 11 , mast, gast; $\mathrm{G}$ of $\mathrm{N}$ 147, gast, mast, wast, hast.

\section{(c) The proportions are:}

The number of rhyme series in Play XII is 47 .

The number of rhyme series in $\mathrm{G}$ of $\mathrm{N}$ is 585 .

The number of agreeing rhyme series is $15 / 47$ of all in Play XII or $31+$ per cent.

The number of rhyme words agreeing is 33 in 144 lines of Play XII or 1 in 5lines.

(6) The analysis of the identical rhyme series in Play XV, the Shepherds, and the Gospel of Nicodemus:

(a) The identical rhymes are:

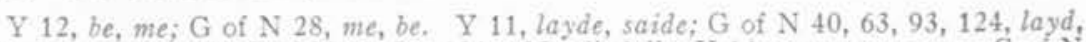
sayd, Y 12, all, falle; G of N 49, 71, 124, 125, all, fall. Y 14, swayne, agayne; G of $\mathrm{N}$ 110 , swayne, ogayne.

(b) The included rhymes are:

Y 2, say, day, lay, maye, saye, maye; G of N 138, say, day, lay, may. Y 11, glade, stadde, hadde; $\mathrm{G}$ of $\mathrm{N} 133$, had, glad, bad, stad. Y 2, borne, by-forne; G of N 20 , 6 born, lorn, sworn, byforn. Y 1, lorne, borne; G of N 20,00 born, lorn, sworn, byforn. Y 12, be, me; G of N 19,70 me, se, fre, be. Y 11, layde, saide; G of N $68,{ }^{n}$ affrayd, payd, layd, sayd. Y 12 , all, falle; G of $\mathrm{N} 32$, all, fall, sall, hall.

(c) The proportions are:

The number of rhyme series in Play XV is 26.

The number of rhyme series in $\mathrm{G}$ of $\mathrm{N}$ is 585 .

The number of agreeing rhyme series is $11 / 26$ of all in Play XV or 42 per cent.

The number of rhyme words agreeing is 25 in 84 lines of Play XV or 1 in $3+$ lines.

(7) The analysis of the identical rhyme series appearing between Play XVII, the Magi, and the Gospel of Nicodemus:

(a) The identical rhymes are:

Y 20 , broght, soght; $\mathrm{G}$ of $\mathrm{N} \mathrm{13,} \mathrm{soght,} \mathrm{broght.} \mathrm{Y} \mathrm{16,} \mathrm{broght,} \mathrm{soght,} \mathrm{noght,} \mathrm{wroght;}$ $\mathrm{G}$ of $\mathrm{N} 23,72$ broght, soght, noght, wroght. $\mathrm{Y} 25$, dele, wele; $\mathrm{G}$ of $\mathrm{N} 72$, dele, wele. $\mathrm{Y} 14$, heuen, neven; $\mathrm{G}$ of $\mathrm{N} 2$, hetuen, neuen. Y 8 , seene, meene; G of N 76, mene, sene. Y 15, marre, werre; G of $\mathrm{N} 137$, ware, mare. Y 19, say, lay, praye, way; G of $\mathrm{N} 105$, say, pray, lay, way. Y 13, anoy, lay, saye, pay; G of $\mathrm{N} 72$, pay, say, lay, oway.

\footnotetext{
" Cf. also $\mathrm{G}$ of $\mathrm{N} 78$, bus, $v 5$, Nichodemus, Ihesus.

"Cf. also $\mathrm{G}$ of $\mathrm{N} 48$, biforne, borne, morne, lorne.

" Ci. also $\mathrm{G}$ of $\mathrm{N} 120$, manere, here, fere, powere; 144, here, manere, powere, yhere.

" Cf. also $\mathrm{G}$ of $\mathrm{N} 37$, pan, man, can, bygan.

" Cf. aiso $\mathrm{G}$ of $\mathrm{N} \mathrm{30,} \mathrm{born,} \mathrm{biforn,} \mathrm{morn,} \mathrm{lorn;} \mathrm{48,} \mathrm{biforne,} \mathrm{borne,} \mathrm{morne,} \mathrm{lorne.}$

$" \mathrm{Cl}$. also $\mathrm{G}$ of $\mathrm{N} 30$, bern, biforn, morn, lorn; 48, biforne, borne, morne, lorne.

$70 \mathrm{Cf}$. also $\mathrm{G}$ of $\mathrm{N} 30$, contre, be, me, degre; 80 , me, be, se, pete.

$n$ Cl. also G of $\mathrm{N} 77$, sayd, layd, affrayd, payd; 145 Add., sayde, brayde, mayde, layde.

$n$ Cf, also $\mathrm{G}$ of N 81, soght, noght, broght, wroght.
} 
(b) The included rhymes are:

$\mathrm{Y} 11$, was, passe; $\mathrm{G}$ of $\mathrm{N} 21,{ }^{73}$ was, pas, Cayphas, was. $\mathrm{Y} 17$, say, may; $\mathrm{G}$ of $\mathrm{N}$ $5,{ }^{74}$ way, say, lay, may, pray, dray. Y 1 , saye, waye; $\mathrm{G}$ of $\mathrm{N} 57^{75}$ way, say, lay, may, pray, dray. $\mathrm{Y} 19$, say, lay, praye, way; $\mathrm{G}$ of $\mathrm{N} 5$, way, say, lay, may, pray, dray. $\mathrm{Y} 19$, stande, hande; G of N 11, 7 land, hand, gleterand, stand. $\mathrm{Y} 1$, saff, hane; G of N $64,{ }^{77}$ saue, graue, haue, strate. Y 27 , contre, be; G of N 30 , contre, be, me, degre. Y 3 , see, bee; G of N 19,78 me, se, fre, be. Y 8 , seene, meene; G of N 11,79 bene, mene, sene, bidene. Y 16, saide, paide; $\mathrm{G}$ of $\mathrm{N} 68,{ }^{80}$ affrayd, payd, layd, sayd. I 15, marre, werre; $\mathrm{G}$ of $\mathrm{N} 14,{ }^{81}$ sware, mare, ware, hare. Y 14 , name, same; $\mathrm{G}$ of $\mathrm{N} 10$, 52 blame, same, schame, name. Y 20, broght, soght; G of N $23,{ }^{33}$ broght, soght, noght, wroght. Y 7, morne, borne; Y 9, byforne, borne; Y 13 , borne, lorne: Y 15, beforne, torne; Y 19 , borne, morne; $\mathrm{G}$ of $\mathrm{N} 30$, s4 born, biforn, morn, lorn. Y 22 , wise, price; $\mathrm{G}$ of $\mathrm{N} 106$, Paradyse, wyse, ryse, pryse. Y 8, stille, ill; G of N 19, styll, vntyll, will, ill. Y 6, skyll, wille; G of $26,{ }^{50}$ vntyll, ill, will, skyll. Y 26 , myght, knyght; G of N 149 Add., knyght, myght, nyght, right. Y 14, heuen, neven; G of N 33, seuen, neuen, heuen, euen.

\section{(c) The proportions are:}

The number of rhyme series in Play XVII is 109.

The number of rhyme series in $\mathrm{G}$ of $\mathrm{N}$ is 585 . cent.

The number of agreeing rhyme series is $31 / 109$ of all in Play XVII or $28+$ per lines.

The number of rhyme words agreeing is 70 in 336 lines of Play XVII or 1 in $4+$

(8) The analysis of the identical rhyme series appearing between Play XX, the Doctors, and the Gospel of Nicodemus:

(a) The identical rhymes are:

Y 21, Jesus, vs; G of N 70, 118, Thesus, vs. Y 2, done, sone; G of $\mathrm{N} 37,5555,129$, done, sone. $\mathrm{Y} 23$, wiffe, liff; G of $\mathrm{N} 16,18$ Add., ${ }^{2}$ ' 150 Add., wyfe, lyf. i 14, men, kene, then, ten; G of N 144, ten, pen, men, ken. Y 8 , yhe, see; G of N $1 \mathrm{~S}, 139$, he, se. $\mathrm{Y} 10$, large, charge; $\mathrm{G}$ of $\mathrm{N} 86$, charge, large. Y 20, saye, ay; $\mathrm{G}$ of $\mathrm{N} 68$, say, ay. Y 7 . laye, saye; $\mathrm{G}$ of $\mathrm{N} 71$, say, lay.

"Cf. also $\mathrm{G}$ of $\mathrm{N} 24$, Cayphas, was, pas, has; 70, was, pas, ass, has; 77. Cayphas, has, was, (ouer) pas; 79, helyas, was, pas, has; 94 , Cayphas, has, Dass, was; 108 . Sathanas, was, pas, has.

$" \mathrm{C}$. also $\mathrm{G}$ of $\mathrm{N} 17$, say, may, lay, oway; 41, lay, say, way, may; 85, day, way, say, may; 110, may, oway, say, ay: 138, say, day, lay, may.

7 Cf. also G of N 17, say, may, lay, oway; 72, pay, say, lay, (o)way; 76, 1ay, ay, say, (o) way; 83, pray, say. (o) way, pay; 85 , day, way, say, may; 89 , pray, lay, say, (o) way; 110 , may, (o) way, say, ay.

$" \mathrm{Ct}$, also $\mathrm{G}$ of $\mathrm{N} 14$, hand, land, stand, hand; 88 , hand, stand, lyfand, vnderstand.

"Cf. also G of N 147 Add., saue, hawe, graue, staue.

" Ci. also G of $\mathrm{N} 50$, plente, he, be, se; 64 , me, tre, se, be; 68 , meneyhe, se, be, Galile; 80 , me, be, se; pete; 135. we, preuete, se, be; 140 , bounte, se, parde, be,

$7 \mathrm{Ct}$. also G of $\mathrm{N} 92$, mene, sene, bidene, wene.

$10 \mathrm{Cf}$. also $\mathrm{G}$ of $\mathrm{N} 77$, sayd, layd, affrayd, sayd.

at. also $\mathrm{G}$ of $\mathrm{N} 21$, mare, sware, spare, ware; 50 .

59. ware, fare, sare, mare; 78 , ware, mare, are, are.

$3 \mathrm{Cf}$. also $\mathrm{G}$ of $\mathrm{N} 48$, sosht

broght, wroght; 124 , soght, wroght, broght, wroght, thoght; 62 , thoght, noght, broght, soght; 81 , soght, noght, $4 \mathrm{Cf}$. also G of N 48, bifort, broght, thoght; 140 , broght, soght, noght, thoght.

$\mathrm{Cf}$. also $\mathrm{G}$ of $\mathrm{N} 48$, biforne, borne, morne, lorne.

a (vn) done.

17 (be)lyae. 


\section{(b) The included rhymes are:}

Y 12 , brede, rede: $\mathrm{G}$ of N 6, rede, dede, brede, wede. Y 20, saye, ay; G of N 55,88 pray, ay, say, day. Y 7 , laye, saye; $\mathrm{G}$ of $\mathrm{N} 5$, s? way, say, lay, may, pray, dray. Y' 1 , mave, wrye; G of $\mathrm{N} 5,00$ way, say, lay, may, pray, dray. Y 17, spare, (no) more; G of 21, mare, sware, spare, ware. Y 21 , Jesus, vs; $G$ of $N 31,01$ pus, Thesus, vs, bus. $\mathrm{Y}$. worough, noght; $\mathrm{G}$ of $\mathrm{N} 10,{ }^{\text {v2 }}$ thoght, noght, broght, wroght. $\mathrm{Y} 2$, done, sone; $\mathrm{G}$ of $36,{ }^{33}$ mon, son, trone, done. Y 24 , tyde, bide; $\mathrm{G}$ of $\mathrm{N} 52,94$ syde, hyde, tyde, byde. Y 23, wiffe, liff; G of N 99, swife, ryfe, dryue, lyfe. Y 13, by, sekirly; G of N 57 , dy, sykerly, by, mercy. Y 11 , mene, bene; $\mathrm{G}$ of $\mathrm{N} 11$, bone, mene, sene, bidene. $\mathrm{Y} 7$, lere, here; $\mathrm{G}$ of $\mathrm{N} 39$, lere, manere, here, here.

(c) The proportions are:

The number of rhyme series in Play XX is 96 .

The number of rhyme series in $\mathrm{G}$ of $\mathrm{N}$ is 585 .

The number of agreeing rhyme series is 21/96 of all in Play XX or 21 per cent.

The number of rhyme words agreeing is 44 in 288 lines of Play XX or 1 in $6+$ lines.

(9) The analysis of the identical thyme series appearing between Play XXIII, the Transfiguration, and the Gospel of Nicodemus:

(a) The identical rhymes are:

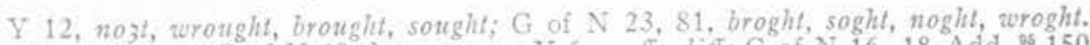
Y 11, bonne, sonne; $\mathrm{G}$ of $\mathrm{N} 60$, bone, sone. Y 6 , wyffe, liff; $\mathrm{G}$ of $\mathrm{N} 16,18 \mathrm{Add},{ }^{95} 150$ Add., wyfe, lvf. Y 7, sight, myght; G of N 89,119 , myght, syght. Y 6, witnesse, is; G of 135,147 , es, witnes. Y 14 , sende, lende; $\mathrm{G}$ of $\mathrm{N} 43$, send, lend. $\mathrm{Y} 18$, stede, dede; $\mathrm{G}$ of $\mathrm{N} 27,62,112,136$, stede, dede. $\mathrm{Y} 12$, helle, tell; $\mathrm{G}$ of $\mathrm{N} 128$, tell, hell. $\mathrm{Y} 20$, me, be; $\mathrm{G}$ of $\mathrm{N} 28$, me, be.

\section{(b) The included rhymes are:}

Y 6, wyffe, liff; G of N 99, wife, ryfe, dryue, lyfe. Y 1, sight, light; G of N 118 , myght, lyght, syght, hyght. Y'7, sight, myght; G of N $5,{ }^{\circ}$ ryght, myght, syght, dyght. $\mathrm{Y} 10$, dight, fyght; $\mathrm{G}$ of $\mathrm{N} 131$, fyght, dyght, myght, ryght. $\mathrm{Y} 19$, sight, wighte; $\mathrm{G}$ of $\mathrm{N}$ 98 , myght, ryght, wight, syght. Y 11, blys, mys; Y 15, his, blisse; G of N 107, mys, blys, his, Iwys Y 6 , witnesse, is; $\mathrm{G}$ of $\mathrm{N} 143$, wilnes, es, halynes, les. Y 14 , sende, lende; $\mathrm{G}$ of $\mathrm{N} 104$, hend, lend, send, end. $\mathrm{Y} 18$, stede, dede; $\mathrm{G}$ of $\mathrm{N} 25,{ }^{97}$ rede, dede, hatred, stede. Y 17 , clene, sene; $\mathrm{G}$ of $\mathrm{N} 61,98$ clene, bene, tene, sene. 'Y 13 , pe, be; $\mathrm{G}$ of $\mathrm{N} 125$, pe, be, se, pete. Y $20, m e, b e ; \mathrm{G}$ of $\mathrm{N} 19,99$ me, se, fre, be. $\mathrm{Y} 19$, priuite,

sa Cf. also $\mathrm{G}$ of $\mathrm{N} 102$, say, pray, ay, day; 110 , may, oway, say, cy; 111, say, verray, oway, ay; $134, a y$, say, may, way.

$" \mathrm{Cf}$. also $\mathrm{G}$ of $\mathrm{N} \mathrm{17,} \mathrm{say,} \mathrm{may,} \mathrm{lay,} \mathrm{oway;} \mathrm{41,} \mathrm{lay,} \mathrm{say,} \mathrm{way,} \mathrm{may;} 42$, bai, allway, lay, say; 72, pay, say, Lay, oway; 89 , pray, lay, say, oway; 105, say, pray. lay, way; 114. lay, say, day, ay; 138, say, day, lay, may; 146 Add, say, play, lay, day.

" Cf. also G of N 17, say, may, lay, (o)way; 41, lay, say, way, may; 85, day, way, say, may; 110, may, o) way, say, ay.

${ }^{11} \mathrm{Cf}$, also G of N 78, pus, "ss, Nichodenus, Ihesus.

$n \mathrm{Cf}$, also $\mathrm{G}$ of $\mathrm{N} 23$, broght, soght, noght, wroght; 66. thoght, wroght, broght, noght; 81, soght, noght, broght, troght.

$w \mathrm{Cf}$. also $\mathrm{G}$ of $\mathrm{N} \mathrm{138,} \mathrm{alssone,} \mathrm{trone,} \mathrm{done,} \mathrm{sone.}$

" Cf. also $\mathrm{G}$ of $\mathrm{N} 145$ Add., tyde, pride, bide, wyde.

"(be)lyue.

w Cf. also G of N 92, ryght, hyght, syght, myght; 118, myght, lyght, syght, hyght.

$"$ Cf. also G of N 58, rede, ded, red, stede; 93 , rede, dede, stede, godhede; 133 , rede, stede, ded, godhede; 143, kynred, ded, stede, godhede.

" Cf. also $\mathrm{G}$ of $\mathrm{N} 119$, bene, clene, sene, kene.

" Cf, also G of N 30, contre, be, me, degre; 80, me, be, se, pete. 
see; G of $\mathrm{N} \mathrm{135,} \mathrm{we,} \mathrm{preuete,} \mathrm{se,} \mathrm{be.} \mathrm{Y} 17$, clere, seere; G of $\mathrm{N} \mathrm{130,} \mathrm{sere,} \mathrm{clere,} \mathrm{were,} \mathrm{here.}$ $\mathrm{Y} 9,18$, name, same; $\mathrm{G}$ of $\mathrm{N} 10,100$ blame, same, schame, name.

(c) The proportions are:

The number of rhyme series in Play XXIII is 80 .

The number of rhyme series in $\mathrm{G}$ of $\mathrm{N}$ is 585 .

The number of agreeing rhyme series is $25 / 80$ of all in Play XXIII or 31 per cent. lines.

The number of rhyme words agreeing is 52 in 240 lines of Play XXIII or 1 in $4+$

(10) The analysis of the identical rhyme series appearing between Play XXIV, the Woman Taken in Adultery and the Raising of Lazarus, and the Gospel of Nicodemus:

(a) The identical rhymes are: Y 13, togedir, pedir; G of N 131, togyder, pider. Y 19, right, sight; G of N 15,74 ,
syght, (vp) ryght. Y 10,11, dede, stede; G of N 27, 62, 112, 136, stede, dede. Y 19, me, be; $\mathrm{G}$ of $\mathrm{N} 28$, me, be. Y 12 , kast, last, past, fast; $\mathrm{G}$ of $\mathrm{N}$ 65, 101 kast, fast, past, last. $\mathrm{Y} 2$, hande, fande; $\mathrm{G}$ of $\mathrm{N} 143$, hand, fand.

(b) The included rhymes are:

$\mathrm{Y} 12$, more, therfore; G of $\mathrm{N} 151$ Add., perefore, lore, (euer)more, sore. Y 18 , myght, light; G of $\mathrm{N} 118$, myght, lyght, syght, hyght. Y 5, tyde, hyde, (a)bide, (gap); $\mathrm{G}$ of $\mathrm{N} 52$, syde, hyde, tyde, byde. Y 12 , frende, wende; $\mathrm{G}$ of $\mathrm{N} 45$ Add., frende, wende, fende, ende. Y 1, 3, synne, blynne; G of N 16,102 mankyn, syn, twyne, blyn. Y 7 , feere, manere; $\mathrm{G}$ of $\mathrm{N} 120,103$ manere, here, fere, powere. Y 8 , sene, clene; $\mathrm{G}$ of $\mathrm{N} 61,104$ clene, bene, tene, sene. $\mathrm{Y} 4$, rede, dede; $\mathrm{G}$ of $\mathrm{N} 6,105$ rede, dede, brede, wede. Y 10,11 , dede, stede; $\mathrm{G}$ of $\mathrm{N} 25,106$ rede, dede, hatred, stede. $\mathrm{Y} 17$, sent, monument; $\mathrm{G}$ of $\mathrm{N} 61,107$ entent, monument, assent, sent. Y 9,15 , see, free; G of N 19 , me, se, fre, be. Y 19 , me, be; $\mathrm{G}$ of $\mathrm{N} 19,108$ me, se, fre, be. Y 8, same, blame; Y 7 , name, schame; G of N 10,102 blame, same, schame, name. Y 14, may, away; $\mathrm{G}$ of $\mathrm{N} 17$, 110 say, may, lay, oway.

(c) The proportions are:

The number of rhyme series in Play XXIV is 70 .

The number of rhyme series in $\mathrm{G}$ of $\mathrm{N}$ is 585 .

The number of agreeing rhyme series is $24 / 70$ of all in Play XXIV or 34 per cent. lines.

The number of rhyme words agreeing is 51 in 209 lines of Play XXIV or 1 in 4

(11) The analysis of the identical rhyme series appearing between Play XXVII, the Last Supper, and the Gospel of Nicodemus:

$100 \mathrm{Ct}$. also G of N 54, name, schame, blame, same.

tat Cf, also $\mathrm{G}$ of $\mathrm{N} \mathrm{112,} \mathrm{fast,} \mathrm{kast,} \mathrm{past,} \mathrm{last.}$

$102 \mathrm{Cf}$. also $\mathrm{G}$ of $\mathrm{N} 75$, blyn, in, bigyn, syn; 123, blyn, syn, herein, wyn.

$19 \mathrm{Cf}$. also $\mathrm{G}$ of $\mathrm{N} 149$ Add., manere, were, powere, yfere.

$104 \mathrm{Ct}$. also $\mathrm{G}$ of $\mathrm{N} 119$, bene, clene, sene, kene.

15 $\mathrm{Cf}$. also $\mathrm{G}$ of $\mathrm{N} 25$, rede, dede, hatred, stede; 58 , rede, ded, red, stede; 93, rede, dede, stede, godhede;
133, rede, stede, ded, godhede.

$104 \mathrm{Cf}$. also G of N 58 , rede, ded, red, stede; 93 , rede, dede, stede, godhede; 133 , rede, stede, ded, godhede;
143. kynred, ded, stede, godhede.

$107 \mathrm{Cf}$. also $\mathrm{G}$ of $\mathrm{N} 67$, monument, went, sent, tent.

$10 \mathrm{Cf}$. also $\mathrm{G}$ of $\mathrm{N} \mathrm{30}$, contre, be, me, degre; 80 , me, be, se, pete.

${ }^{103} \mathrm{Cf}$. also G of N 54, name, schame, blame, same.

uo Cf. also G of N 110, may, oway, say, ay. 


\section{(a) The identical rhymes are:}

$\mathrm{Y} 4$, sone, done; $\mathrm{G}$ of $\mathrm{N} 37, \mathrm{m1} 55,129$, sone, done. Y 16, me, bee; G of $\mathrm{N} 28$, me, be. Y 14, divell, Israell; G of N 76, dwell, Israel. Y 11, steede, dede; G of N 27, 62, 112,136 , stede, dede. Y 9, paste, laste; G of N 106, last, past. Y 3, all, call, small, befall; G of N 58, all, bifall, call, small.

(b) The included rhymes are:

$\mathrm{Y} 4$, sone, done; $\mathrm{G}$ of $\mathrm{N} 36,112$ mon, son, trone, done. $\mathrm{Y} 15$, striffe, liff; $\mathrm{G}$ of $\mathrm{N}$ 122 , lyue, stryue, bilyue, dryue. Y 7 , (be)tyde, bide; G of N 52,113 syde, hyde, tyde, byde. Y 16 , me, bee; G of $\mathrm{N} 19,11$ me, se, fre, be. Y 4 , see, pee; G of $\mathrm{N} 125$, pe, be, se, pete. Y 14, dwell, Israell; G of N 108, hell, dwell, Israel, dwell. Y 11, steede, dede; $\mathrm{G}$ of $\mathrm{N} 25,15 \mathrm{rede}$, dede, hatred, stede. $\mathrm{Y} 11$, lende, wende; $\mathrm{G}$ of $\mathrm{N} 40$, hend, lend, kend, wend. Y 6 , trewe, newe; G of N 7,116 trew, Ihesu, new, knew. Y 9, paste, laste; G of N $65,{ }^{117}$ kast, fast, past, last. Y 1 , has, paas; G of $\mathrm{N} 24,118$ Cayphas, was, pas, has. Y 15 , haue, saue; G of $\mathrm{N} 64,{ }^{119}$ saue, graue, haue, straue.

(c) The proportions are:

The number of rhyme series in Play XXVII is 62 .

The number of rhyme series in $\mathrm{G}$ of $\mathrm{N}$ is 585 .

The number of agreeing rhyme series is $18 / 62$ of all in Play XXVII or $29-$ per cent.

The number of rhyme words agreeing is 38 in 187 lines of Play XXVII or 1 in 5 lines.

(12) The analysis of the identical rhyme series appearing between Play XXXV, the Crucifixion, and the Gospel of Nicodemus:

(a) The identical rhymes are:

$\mathrm{Y} 6$, sone, done; G of $\mathrm{N} 37,12055,129$, sone, done. Y 10, doo, too; G of N 33, (vn)to, do. Y 16 , side, (a)bide, tyde, hyde; G of N 52, syde, hyde, tyde, byde. Y 13, me, see; $\mathrm{G}$ of $\mathrm{N} 132$, me, se. Y 23 , certayne, agayne; G of N 151 Add., agayne, certayne. Y 2 , all, schall; $\mathrm{G}$ of $\mathrm{N} 44,134$, all, sall. Y 18 , caste, laste, faste, paste; G of N 112, fast, kast, past, last.

\section{(b) The included rhymes are:}

$\mathrm{Y} 6$, sone, done; G of $\mathrm{N} 36,{ }^{121} \mathrm{mon}$, son, trone, done. Y 24, mone, sone; G of N 36 , mon, son, trone, done. Y 22 , noght, sought; $\mathrm{G}$ of $\mathrm{N} 23$, 122 broght, soght, noght, wroght. $\mathrm{Y} 1,100$, doo; G of N 35,20 , do, vnto, bro. Y 24 , stille, wille; G of N 19 , styll, vntyll, will, ill. Y 1 , fullfille, tille; $\mathrm{G}$ of $\mathrm{N} 93,{ }^{223}$ will, tyll, skyll, fullfyll. $\mathrm{Y} 14$, light, hight;

iii (vn)done,

in $\mathrm{Cf}$, also $\mathrm{G}$ of $\mathrm{N}$ 138, alssone, trone, done, sone.

us $\mathrm{Ct}$. also $\mathrm{G}$ of $\mathrm{N} 145$ Add., tyde, pride, bide, wyde.

$m \mathrm{Cf}$. also $\mathrm{G}$ of $\mathrm{N} 30$, contre, be, me, degre; 64 , me, tre; se, be; $80, m e$, be, se, pete.

un 58 , rede, ded, red, stede; 93 , rede, dede, stede, godhede; 133 , rede, stede, ded, godhede; 143 , kynred, ded, stede, godhede.

${ }^{m} \mathrm{Cl}$. also $\mathrm{G}$ of $\mathrm{N} 18$, Iew, nets, trew, rew.

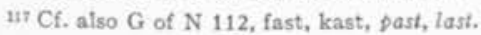

ut $\mathrm{C}$. also $\mathrm{G}$ of $\mathrm{N} 70$, was, pas, ass, has; 77. Cayphas, has, was, (ouer) pas; 79, helyas, was, pas, has; 94, Cayphas, has, pass, was; 108, Sathanas, was, pos, has.

in Cf. also G of N 147 Add., saue, haue, graue, staue.

iss (vn) done.

12: $\mathrm{Cl}$. also $\mathrm{G}$ of $\mathrm{N}$ 138, alssone, trone, done, sone.

is $\mathrm{Ct}$, also $\mathrm{G}$ of $\mathrm{N} 62$, thoght, noght, broght, soght; 81 , soght, noght, broght, wroght; 140, broght, soght, noght, thoght.

iz Ct. aiso $\mathrm{G}$ of $\mathrm{N} 123$, ill, tyll, skyll, fullfyll. 
G of N 118, myght, lyghl, syght, hygltt. Y 9, blynne, ynne; G of N 75, blyn, in, bigyn, syn. Y 7, feste, beste; G of N 53, best, threst, west, fest. Y 19 , felle, telle; $\mathrm{G}$ of $\mathrm{N} 2^{124}$ Gamaliel, fell, spell, tell. Y 5, fende, ende; G of N 45 Add., frende, wende, fende, ende. Y 13, me, see; G of N 19,125 me, se, fre, be. Y 17, we, bee; G of N 71,126 we, cete, Galile, be. Y 2, all, schall; $\mathrm{G}$ of $\mathrm{N} 100$, wi (with) all, thrall, sall, bifall. Y 20 , smale, all; $\mathrm{G}$ of N $26,{ }^{123}$ hall, all, small, call.

(c) The proportions are:

The number of rhyme series in Play XXXV is 100.

The number of rhyme series in $\mathrm{G}$ of $\mathrm{N}$ is 585 .

The number of agreeing rhyme series is $22 / 100$ of all in Play XXXV or 22 per cent.

The number of rhyme words agreeing is 48 in 300 lines of Play XXXV or 1 in $6+$ lines.

(13) The analysis of the identical rhyme series of Play XLIV, the Descent of the Holy Spirit, and the Gospel of Nicodemus:

(a) The identical rhymes are:

$\mathrm{Y} 19$, boune, sone; G of $\mathrm{N} 60$, bone, sone. Y 10, myght, light, highte, sight; $\mathrm{G}$ of $\mathrm{N}$ 118 , myght, lyght, syght, hyght. Y 17, myght, sight; G of N 89,119 , myght, syght. Y 5 , hyde, tyde, bride, (a)side; G of N 52, syde, hyde, tyde, byde. Y 19, be, me; G of N 28, me, be. Y 6 , hende, sende; $\mathrm{G}$ of $\mathrm{N} 56$, hend, send. Y 15 , drede, nede; $\mathrm{G}$ of $\mathrm{N} 42,140$, dred, nede. Y 12, heuyn, euyn; G of $\mathrm{N} 84,99$, heuen, euen. Y 11, emang, sange; G of N 8, sang, omang.

(b) The included rhymes are:

Y 5, till, still; G of N 19, ${ }^{120}$ styll, (vn)tyll, will, ill. Y 17, myght, sight; G of N 5,130 ryght, myght, syght, dyght. Y 2, wise, avise; G of N 141, avyse, prophecyse, clergyse, wyse. $\mathrm{Y} 19, b e$, me; $\mathrm{G}$ of $\mathrm{N} s 0$, me, be, se, pete. $\mathrm{Y} 7$, wente, senie; $\mathrm{G}$ of $\mathrm{N} 67,131$ monument, wenl, senl, tent. Y 15, drede, nede; G of $\mathrm{N} 110$, forbede, nede, drede, lede. Y 12 , hewyn, euyn; G of N 33, seuen, neuen, hewen, euen. Y 6, haue, saue; G of N 64, isa saue, graue, haze, stratue.

\section{(c) The proportions are:}

The number of rhyme series in Play XLIV is 71 .

The number of rhyme series in $\mathrm{G}$ of $\mathrm{N}$ is 585 .

The number of agreeing rhyme series is $17 / 71$ of all in Play XLIV or $24-$ per cent. lines.

The number of rhyme words agreeing is 38 in 224 lines of Play XLIV or 1 in 6

(14) The analysis of the identical rhyme series ${ }^{133}$ appearing between the Towneley Conspiracio (the Northern Septenar strophes) and the Gospel of Nicodemus:

\footnotetext{
ia Cf. also $\mathrm{G}$ of $\mathrm{N} 117$, tell, hell, fell, snell; 150 Add., telle, spelle, felle, elle.

is Cf. also $\mathrm{G}$ of $\mathrm{N} 80, \mathrm{me}$, be, se, pete; 89 , he, se, we, me.

in Cf. also $\mathrm{G}$ of $\mathrm{N}$ 101, we, he, gle, be; 135, we, prevete, se, be.

in Ct, also G of N 114, all, bifall, sail, small; 132, all, sall, call, sall.

is Cf. also G of N 114, ell, bifall, sall, small.

w Cf. also $\mathrm{G}$ of $\mathrm{N} 49$, styll, tyll, sicyll, spyll.

$120 \mathrm{Cf}$. also $\mathrm{G}$ of $\mathrm{N} 92$, тyght, hyght, syght, myght; 118, myght, lyght, syght, hyght.

in Cf. also G of $\mathrm{N} 76$, hent, present, sent, went; 84, sent, ment, went, entent.

in Cf. also G of $\mathrm{N} 147$ Add., saue, hane, graue, staue.
} form.

in I have retained Mr. Pollard's numbering although it does not correspond to the Northern Septenar 
(a) The identical rhymes are:

T 23, wyll, tyll; G of $\mathrm{N} \mathrm{12,14,134tyll,} \mathrm{will.} \mathrm{T} \mathrm{10,} \mathrm{present,} \mathrm{assent;} \mathrm{G} \mathrm{of} \mathrm{N} \mathrm{31,} \mathrm{pres-}$ ent, assent. T 28, ken, men, then, ten; G of $\mathrm{N} 144$, ten, pen, men, ken. $\mathrm{T} 19$, els, divelles, mels, tels; $\mathrm{G}$ of $\mathrm{N} 35$, dwelles, telles, melles, elles. T 27, avayll, counsayll; $\mathrm{G}$ of N 149 Add., availe, consaile. T 28, take, wake, sake, make; G of N 84, make, (for) sake, wake, take. T 16, say, day; $\mathrm{G}$ of $\mathrm{N} 23,28,57$, say, day.

(b) The included rhymes are:

T 31, skyll, will; G of $\mathrm{N} 26,135$ vntyll, ill, will, skyll. T 45, hight, myght; G of $\mathrm{N}$ $92,{ }^{136}$ ryght, hyght, syght, myght. T 25 , went, assent; G of N 129, went, assent, hent, entent. T 33, we, be: $\mathrm{G}$ of $\mathrm{N} 71,{ }_{137}$ we, cete, Galile, be. T 15 , thus, vs; $\mathrm{G}$ of $\mathrm{N} 31,{ }^{138}$ pus, Ihestus, $v s$, bus. T 41, seyn, teyn; G of $\mathrm{N} 45$, sene, wene, tene, bene. T 39 , wroght, broght; $\mathrm{G}$ of $\mathrm{N} 48$, soght, broght, wroght, thoght. T 25 , kyd, byd; $\mathrm{G}$ of $\mathrm{N} 6$, byd, kyd, hyd, dyd. T $37, y l l$, styll; G of N 19, styll, vntyll, will, ill. T 33, say, pay; G of $\mathrm{N}$ 47.130 pray, day, pay, say. T 47, glad, had; G of $\mathrm{N} 133$, had, glad, bad, stad.

(c) The proportions are:

The number of rhyme series in the Towneley play is 85 .

The number of rhyme series in $\mathrm{G}$ of $\mathrm{N}$ is 585 .

The number of agreeing rhyme series is $18 / 85$ of all in the Towneley play or $21+$ per cent.

The number of rhyme words agreeing is 42 in 264 lines of the Towneley play or 1 in 6 lines.

The preceding analysis indicates that practically the same relationship, as regards the presence of identical rhymes, exists in the Gospel of Nicodemus and each of the York plays composed in the Northern Septenar form. The Harrowing of Hell, clearly a revised play because of the different description accorded it by Burton in the list, ${ }^{140}$ and containing as it does, both the subject-matter and the stanzaic form of the Gospel of Nicodemus, seems to be a fair standard by which to compare the other plays. In the proportion of rhyme series, only two plays (XI and XX) fall below 22 per cent, the standard set by the Harrowing of Hell, and one play (XV) almost doubles this proportion. In the number of agreeing rhyme words, no play falls below the standard. The Northern Septenar strophes in the Towneley Conspiracio also show a similar influence.

Since the material derived from the Gospel of Nicodemus represents a later addition to the York cycle, the adoption of its metrical form is likewise to be regarded as a later innovation. The Harrowing of Hell, which combines both the subject-matter and the metre of the source, was probably one of the first plays revised. Three other plays, XXIX, XXX, XXXIII, showing the influence of Nicodemus material, were probably

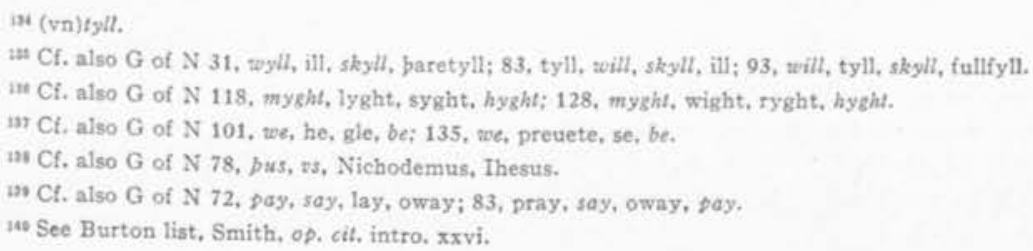


originally composed in the Northern Septenar, and subsequently altered to their present metrical forms. ${ }^{141}$ The great number of plays extant in the Northern Septenar stanza or later modifications of $i^{142}$ point to an extensive revision.

Scriptural accuracy and doctrinal correctness appear to be characteristics of the Northern Septenar plays, characteristics which were not entirely lost sight of even in succeeding revisions. One of the craft records shows the Masons protesting against supporting their play any longer, on the express ground that it had no scriptural basis. ${ }^{143}$

The York plays, on the whole, are reverent and seemly in tone; ${ }^{14}$ they are generally regarded as uninteresting and conventional in material and as formal, dignified, and serious in manner. ${ }^{145}$ For the most part, they follow Biblical accounts with only occasional deviations into apocryphal legends. ${ }^{146}$ The doctrinal object of the whole scheme of the mysteries is seldom lost sight of in the development of individual plays. Isaac is not the terrified youth of the other English plays, but a prototype of Christ himself, a man of thirty years, calm and resigned in the face of God's command. ${ }^{147}$ In the play of Cain and Abel, the duty of paying tithes is emphasized by the angel who delivers the message from the Deity. ${ }^{148}$ Although incidents from the Northern Passion have been used in developing the play of the Last Supper, they have been rearranged according to the order given in the Gospel of St. John. ${ }^{149}$

In contrast to the Towneley cycle, Ten Brink ${ }^{150}$ has already pointed out certain features of the York plays which indicate scriptural accuracy or fitting moderation. "In the play of the Deluge," he says, "Noah's wife is obstinate and quarrelsome, as may be expected of her, but there appears at least some motive for her conduct, and the composure and patience of the patriarch are guaranties that the conjugal quarrel will be maintained within definite bounds. The York Pilate is conceived to some extent, as human and not so much caricature and even the Herod of the history of the Passion shows some touches of justice. At the trial of Christ before the High Priest, Annas and Caiaphas have, as it were, changed parts; yet the York Annas is very far from being raised to that

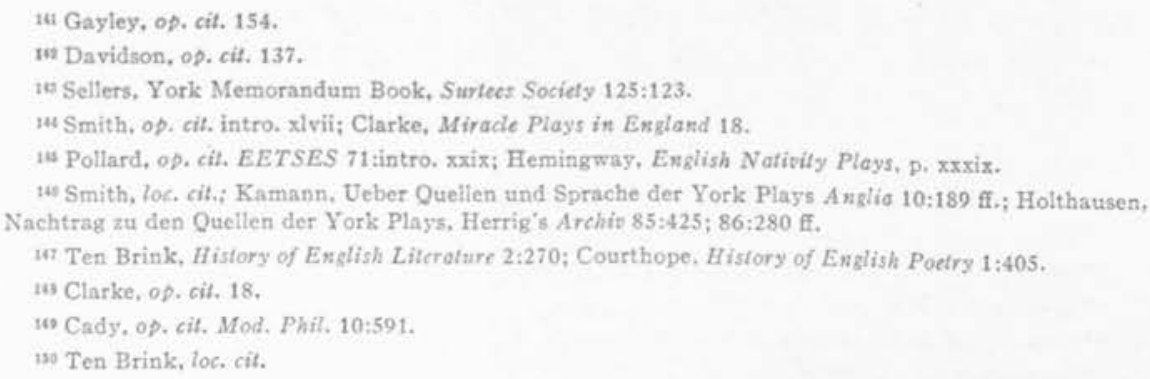


fiendish ingenuity of spiteful wickedness which astonished us in the Woodkirk Caiaphas." Probably, then, revisions at York were influenced, to some extent, by a desire to redeem the plays from the disrepute into which they had fallen in the fourteenth century. ${ }^{151}$

There were, it would seem, two principles underlying the York revisions, those of expansion and contraction. Expansion is seen in the use of more complicated stanzaic forms whose rhyme schemes demanded an expansion in phraseology, and in the introduction of additional apocryphal material; contraction is seen in the omission of certain incidents not conformable to scriptural accounts or to accepted authorities. These principles, as the basis of the York revisions, will be considered in the discussion of the individual plays. ${ }^{152}$

\section{The Old Theory of a York Parent Cycle Untenable}

Since it is probable that the Northern Septenar metre in the York cycle belongs to the period of revision, it becomes clear that the plays occurring in that metre can no longer be regarded as the remains of the parent cycle, as argued by $\mathrm{Mr}$. Davidson. ${ }^{153}$ Assuming that the parent cycle must have been written by one man in a single metre, he selected the plays in the Northern Septenar stanza because they were the only plays having an identical metre which, he believed, could possibly have formed a cycle. ${ }^{154}$ This assumption, however, seems untenable.

In the first place, the incidents which form the subject of the Northern Septenar plays are not those which would certainly have been included

1m Robert Grossetete and Robert de Brunne considered attendance at the mysteries a sinful act. See Collier, A nvels of the Stage $6 \mathrm{ff}$. The ranting of Herod and Pilate had become stock situations by Chaucer's time. See the Milier's Prologue and Tale.

17 See below, ch. IV.

in Davidson, op. cit. $137 \mathrm{ff}$. Mr. Davidson's theory has been generally accepted: see Coblentz. Mod. Lang. Notes 10:77; Gayley, op. cit. $153 \mathrm{ff}$., Representatire English Comedies intro. xxiv, Internat. Quart. $10: 125$; Caciy, op. cit. Mlod. Phil. 10:590. Previous to Mr. Davidson's study. Professor Hohlfeid (op. cit. Anglia 11:248) suggested that the Northern Septenar plays, because of their dignified and religious character, were just such plays as would surely have belonged to an original cycle, with the possible exception of XI, XXIII, and part of XXIV.

$14 \mathrm{By}$ means of rhyme scheme tests indicating a common authorship, Mr. Davidson (op, cit. $137 \mathrm{ff}$ ) includes the following plays in his proposed parent cycle: II, the Creation to the Fifth Day, VIII, the Building of the Ark. IX, Noah and His Wife, the Flood and Its Waning. X. Abraham's Sacrifice of Isagc. XI1, the Annunciation, the Prologue, XV, the Angeis and the Shepherds (the first three strophes and the last four, omitting the comic episodes). XVII, the Coming of the Three Kinss fo Herod, the Adoration (strophes 22, 23, 24, he thinks may have been rewritten), XX, Christ with the Doctors in the Temple, XXIII, the Transfiguration. XXIV, the Woman Taken in Adulfery, the Raising of Lasarus, W. XX. Conspiracio (Towneley) from "Cayphas" to "Tunc dicet Sanctus Johannes," later supplanted in York. XXVII, the Last Supper, XXXV, the Crucifixion, XXXVII, the Harrotoing of Hell. XLIV, the Descent of the Holy Spirit. Mr. Davidson, however, is not justified in including the Annunciation. It occurs in double quatrains, as does the Visil fo Elizabeth, and is part of the same play. If he includes the one, he has no reason, it would seem to omit the other. Since he does not apply his rhyme scheme tests to the double quatrains of this play, he presents no proof showing their connection with the Northern Septenar strophes. and therefore, is not entitled to include the Anvunciotion in his parent cycle. Other scholars have also expressed opinions regarding the legitimacy of including certain plays. Mr. Coblentz (Mod. Lang. Notes 10:77) accepts all of Davidson's parent cycle except the Wakefield Conspiracio. Professor Gayley (Plays of Our Forefathers 153, n. 1) omits Play IX. 
in a cycle developed from liturgical plays. ${ }^{155}$ Of the nine incidents clearly demanded by any Nativity and Resurrection liturgical groups, the Prophetae, the Annunciation, the Nativity, the Shepherds, the Magi, the Quem Quaeritis, the Hortulanus, the Peregrini and perhaps the Incredulity of Thomas, Mr. Davidson's cycle includes but three, the Prophetae, the Shepherds, and the Magi.

Besides this omission of certain essential plays, the proposed parent cycle includes plays which could have been present, it would seem, only in a fairly complete cycle. The most striking case is that of the Transfiguration, which is not found in any of the other highly developed English cycles. Although plays dealing with Christ's ministry, such as the Doctors, the Woman Taken in Adultery, and Lazarus, may have existed in the parent cycle, their presence in an early stage seems unlikely since the material which they treat is not fundamental in cyclical formation.

Moreover, Mr. Davidson himself admits the superior age of certain other plays of supposed "church origin."'156

\section{Separation of the York and TOWNeley Cycles}

The contact between York and Towneley must have extended into the period in which the influence of the Gospel of Nicodemus was felt, because two of the plays common to both cycles, the Harrowing of Hell and the Resurrection, include material derived from that source. The separation must have occurred, however, before that material was completely assimilated, for three York plays incorporate Nicodemus material ${ }^{157}$ while the corresponding Towneley plays show no trace of it. Moreover, the number of York plays in the Northern Septenar metre far exceeds the number of Towneley plays in the same metre, thus indicating that, in all probability, the Towneley cycle includes certain plays of the parent cycle which, at York, were subsequently turned into the Northern Septenar metre or other stanzaic forms.

\footnotetext{
in The reference in the Stathtes of York Cathedral to the Pastores and Stella (Lincoln Statutes 2:98; Chambers, The Medieval Stege 2:399; Craig. Origin of the Old Testament Plays Mod. Phil. 10:485) makes it probable that the York cycle had its origin in the liturgy, and that York had liturgical plays of the Nativity and probably the Resurrection. Since it can not be determined at present, whether or not there existed at York a liturgical play on the Passion, the Passion group will not be included in the present discussion. See Chambers, op. cit. 2:ch. xviii-xxii; Cady, op. cil Mod. Phil. 10:587 ff.; and above, ch. I. p. 29.

in Davidson, op. cit. 137.

is See above, p. $30 \mathrm{ff}$.
} 


\section{CHAPTER III}

\section{THE INTERRELATION OF THE YORK AND TOWNELEY METRES}

In the identical plays of the York and Towneley cycles, ${ }^{1}$ four distinct metres occur, the Northern Septenar, the "Burns" measure, the double quatrain, and the ten-line (six plus four) stanza, ${ }^{2}$ rhyming aabaabcbcb. If the identical plays be regarded, not as "borrowings" on the part of Towneley from York, but as existing in the period before York and Towneley became separate cycles, we shall have to do with three stages in the development of metrical forms: the parent cycle, with its characteristic metres, and the York and Towneley cycles, each with its characteristic metres introduced after the separation. Since the greater part of six plays of the parent cycle escaped revision in both cycles, it is possible that certain other plays were revised in one cycle but remained practically unchanged in the other. Some of these plays may be determined by means of metrical forms common to both cycles.

Apparently, a common Resurrection group composed entirely in the "Burns" stanza originally existed in the parent cycle. The theory that Towneley "borrowed" certain plays from York encounters serious difficulties in the case of the Resurrection. To suppose that Towneley already possessed a Resurrection group but wished to exchange its own play for the York Resurrection seems improbable; to suppose that the Towneley cycle, at that time, was so small and incomplete that the York Resurrection was borrowed to fill an existing gap is likewise inconceivable, for no matter how small or incomplete a cycle might have been, it would certainly have included a Resurrection proper. ${ }^{3}$ The very core of a Resurrection group is in the Resurrection proper, and without that, the existence of a group of Resurrection plays would be impossible. If Towneley did not possess a play of the Resurrection proper before such a supposed borrowing, then it could not have possessed other plays immediately following the actual resurrection of Jesus, such as the Appearance of Jesus to Mary Magdalene, the Peregrini, and the Incredulity of Thomas. Practically a complete Resurrection group composed in the "Burns" stanza is still extant in individual plays of either one cycle or the other: the Resurrection proper, still identical in both cycles, the Towneley Peregrimi (most of it), the York Incredulity of Thomas, and two strophes of the Towneley

The Pharaoh, the Doctors, and the Harroring of Hell are written in the Northern Septenar, the Resurrection in the "Burns" measure, the Last Judgment in double quatrains, and On the Way to Calsary in the ten-line stanza.

" Saintsbury, History of English Prosody 1:209.

a Chambers, ibid. 2 :ch. xviii-xxii. 
Appearance of Jesus to Mary Magdalene. A Resurrection group naturally includes these four incidents, and therefore it seems reasonable to conclude that the parent cycle included a complete Resurrection group in the "Burns" stanza.

The parent cycle may also have included certain other plays in the "Burns" metre. Perhaps the Towneley Suspencio Iude and Magi and the York Expulsion belong to this stage. Similarities in stanzaic form, verse movement, and lack of structural alliteration connect these plays with those of the Resurrection group in the same metre. The use of identical rhymes, though less evident, may be considered significant in indicating a common influence.

The York Resurrection will be selected as the standard by which to compare all the plays occurring in the "Burns" metre.

(1) The analysis of the identical rhyme series occurring between York XLII, the Incredulity of Thomas, and York XXXVIII, the Resurrection:

(a) The identical rhymes are:

Y XLII:26, feele, wele; Y XXXVIII:22, fele, wele. Y XLII:13, me, see; Y XXXVIII:32, see, me. Y XLII:23, (vn)wise, rise; Y XXXVIII:27, ryse, wise.

(b) The included rhymes are:

Y XLII:18, man, wan; Y XXXVIII:16, wanne, blanne, manne, panne. Y XLII:22, gang, mang: Y XXXVIII:10, (a)mong, gang, lang, wrang. Y XLII:19, pyne, tyne; Y XXXVIII:33, pyne, tyne, medicyne, hyne. Y XLII:23, (vn) wise, rise; YXXVIII:6, wise, rise, dispise, assise. Y XLII:2, sloo, goo; Y XXXVIII:57, goo, soo, sloo, woo. Y XLII: 17 , morne, lorne; Y XXXVIII:65, borne, beforne, morne, lorne. Y XLII:5, soghte, broght, pought; Y XXXVIII:40, pought, sought, brought, noght,

(c) The proportions are:

The number of rhyme series in York XLII is 66.

The number of rhyme series in York XXXVIII is 152. cent.

The number of agreeing rhyme series is $10 / 66$ of all in York XLII or $15+$ per lines.

The number of rhyme words agreeing is 21 in 198 lines of York XLII or 1 in $9 \mathrm{r} / 2$

(2) The analysis of the identical rhyme series appearing between York XXII, the Temptation, and York XXXVIII, the Resurrection;

(a) The identical rhymes are:

Y XXII:3, fende, ende; Y XXXVIII:6, (of)fende, ende. Y XXII:8, ill, will; Y XXXVIII:10, will, ill. Y XXII:31, till, will; Y XXXVIII:71, (vn)till, will.

(b) The included rhymes are:

Y XXII:16, falle, schall; Y XXXVIII:68, schall, all, call, (be)fall. Y XXII:25, hende, frende; Y XXXVIII:44," layne, wende, frende, hende. Y XXII:27, wende, ende; Y XXXVIII:58, hende, wende, frendes, ende. Y XXII:17, myght, sight; Y XXXVIII:32, dight, wight, sight, myght. Y XXII:13, allone, ilkone; Y XXXV', sight; 1 ilkone, allone, anone, gone. Y XXII:6, 10, moo, two; Y XXXVIII:38, moo, also, goo, to. Y XXII:5, borne, morne; Y XXXVIII:65, borne, beforne, morne, lorne.

4 Cf. also Y XXXVIII:58, hende, wende, frendes, ende.

CCf. also Y XXXVIII:64, (euer) ilkone, stone, none, allone. 


\section{(c) The proportions are:}

The number of rhyme series in York XXII is 70 .

The number of rhyme series in York XXXVIII is 152 .

The number of agreeing rhyme series is $10 / 70$ of all in York XXII or $14+$ per cent.

The number of rhyme words agreeing is 20 in 210 lines of York XXII or 1 in 10 lines.

(3) The analysis of the identical rhyme series appearing between York VI, the Expulsion, and York XXXVIII, the Resurrection:

(a) The identical rhymes are:

$\mathrm{Y}$ VI:28, wrange, emange, lange, gange; Y XXXVIII:10, among, gang, lang, wrang. Y VI:2, tille, wille; Y XXXVIII:71, (vn)till, will. Y VI:24, gilte, spilte; Y XXXVIII:46, spilte, gilte.

(b) The included rhymes are:

Y VI:23, bydene, sene; Y XXXVIII:3, ${ }^{\circ}$ mayntayne, bedene, wene, sene. Y VI:25, pought, nought; Y XXXVIII:57, pought, sought, brought, noght.

(c) The proportions are:

The number of rhyme series in York VI is 58.

The number of rhyme series in York XXXVIII is 152 .

The number of agreeing rhyme series is $5 / 58$ of all in York VI or $9+$ per cent.

The number of rhyme words agreeing is 14 in 168 lines of York VI or 1 in 12 lines.

(4) The analysis of the identical rhymes appearing between Towneley XXVII, the Peregrini, and York XXXVIII, the Resurrection:

(a) The identical rhymes are:

T 26, drede, yede; Y 62, 3ede, drede. T 60, thus, vs; Y 70, pus, vs.

(b) The included rhymes are:

T 51, away, say; Y $27,{ }^{7}$ saie, purvaye, may, away. T 28 , saw, knaw; Y $20,{ }^{8}$ withdrawe, awe, sawe, knawe. T 16, tre, me; Y 46, me, three, free, tre. T 32 , be, se; Y 37 , free, see, be, thre. T 6 , ded, red; Y $4,{ }^{9}$ steede, hede, dede, rede. T 11 , dede, yede; T 26 , drede, yede; Y 54, dede, zede, drede, nede. T 18, two, go; Y 43, soo, froo, too, goo.

(c) The proportions are:

The number of rhyme series in Towneley XXVII is 76 .

The number of rhyme series in York XXXVIII is 152.

The number of agreeing rhyme series is $10 / 76$ of all in Towneley XXVII or $13+$ per cent.

The number of rhyme words agreeing is 20 in 246 lines of Towneley XXVII or 1 in 12 lines.

(5) The analysis of the identical rhyme series appearing between Towneley XIV, the Magi, and York XXXVIII, the Resurrection:

t. Cf. also Y XXXVIII:8, mene, sene, bedene, wene.

$7 \mathrm{Cf}$. also Y 29 , maye, day, away, saic; 49 , saie, laye, awaye, ay; 71, saie, daye, araye, atcaye.

\& Cf. also Y 61, sawe, knawe, awe, drawe.

- Cr. also Y 53, rede, dede, steede, hede. 
(a) The identical rhymes are:

$\mathrm{T} 33$, vs, thus; Y 70 , pus, vs. T 43 , morne, borne, lorne, beforne; $\mathrm{Y}$ 65, borne, beforne, morne, lorne. T 50 , to, do; Y 24 , (per)to, do. T 38, 85, wyll, vntyll; Y 71 , ontill, will. $\mathrm{T} 81$, heynd, weynd, leynd, freynd; $\mathrm{Y} 44$, layne (lende), wende, frende, hende. T 40, hende, ende; Y 26, hende, ende. T 73, me, se; Y 32, see, me. T 41, red, sted, hed, ded; Y 4, 53, steede, hede, dede, rede. T 46, way, say; Y 56, way, saie. T 78, say, lay, way, may; Y 41, saie, laye, may, way.

(b) The included rhymes are:

T 23, none, alone; Y 64, (euer)ilkone, stone, none, allone. T 90, broght, soght; $\mathrm{Y} 40$, pought, sought, brought, noght. T 80 , fro, so; Y $25,{ }^{10}$ soo, goo, froo, moo. T 3 , ying, thyng; Y $5,{ }^{11}$ thyng, beriyng, ping, thidingis. T 13 , ying, kyng; T 63 , thyng, kyng; $\mathrm{Y} 15$, thyng, ping, mornyng, kyng. T 48 , rewe, knew; Y 14 , rewe, enewe, trewe, knewe. $\mathrm{T} 40$, hende, ende; T 97, ende, weynd; T 101, heynd, weynd; Y 58, hende, wende, frendes, ende. T 36,104 , cuntre, be; T 24,34 , me, be; Y 1 , me, degre, contre, be. T 58 , me, thre; $\mathrm{Y} 46$, me, three, free, tre. T 17,89 , cuntre, se; Y 74 , contre, degre, be, see. T 22, weynd, send; $\mathrm{Y} 73$, amende, kende, sende, wende. $\mathrm{T} 103$, manere, sere; $\mathrm{Y} 36$, dere, manere, clere, sere. T 46, way, say; Y 41,12 saie, laye, may, way. T 83, away, say; Y $27,{ }^{12}$ saie, purvaye, may, away.

(c) The proportions are:

The number of rhyme series in Towneley XIV is 206.

The number of rhyme series in York XXXVIII is 152.

The number of agreeing rhyme series is $26 / 206$ of all in Towneley XIV or $12+$ per cent.

The number of rhyme words agreeing is 60 in 630 lines of Towneley XIV or 1 in $10+$ lines.

The proportion of identical rhyme series occurring in the York plays under discussion and the York Resurrection, selected as a standard, varies from ten to fifteen per cent; the proportion between the Towneley plays and the standard falls within the same limits, namely, twelve and thirteen per cent. The proportion of identical words is also similar: the York plays show an identity with the standard in from one in nine and one half lines to one in twelve lines; the Towneley plays from one in ten lines to one in twelve lines. It is, then, apparent that the plays of both cycles in the "Burns" metre were composed under the same influence, and must, therefore, represent plays of the parent cycle.

The presence in the Towneley cycle of certain plays in the Northern Septenar ${ }^{14}$ and in the "Burns" measure, shown by rhyme scheme tests to be plays of the parent cycle, supplanted in York by other versions, leads to the conclusion that other plays of the parent cycle in other metres may now exist in Towneley. The Last Judgment, in double quatrains, and $O n$ the Way to Calvary, in the ten-line (six plus four) stanza, practically identical in the two cycles, are cases in point. The Towneley Abraham

is $\mathrm{Ct}$. also $\mathrm{Y} 69$, soo, froo, g00, mo.

n Cf. also $\mathrm{Y} 15$, thyng, ping, mornying, kyng.

12 Cf. aiso Y 43, saie, daye, maye, waye; 52 , day, waye, saie, affraye.

s Cf. also Y 29, maye, day, away, soie; 49, saie, laye, awaye, ay; 71, saie, daye, araye, awaye.

1 See Davidson, op. cit. 144. 
and Isaac as well as John the Baptist, ${ }^{15}$ occur in double quatrains similar to those of the Last Judgment, and like the plays in the Northern Septenar and "Burns" metres, may perhaps also be regarded as parent plays subsequently revised in York. The presence in the Towneley Talents of strophes rhyming $a b a b c b c$ may bear some connection with the York plays in the same metre, the Nativity, the Baptism, and the Entry. It is even possible that the parent cycle made a more extended use of this metre than is apparent in the extant plays: the play of the Talents, now omitted from the York cycle but described in a 1422 record, ${ }^{16}$ may be partly preserved in the ababcbc strophes of the Towneley play. ${ }^{17}$ Some significance may also be attached to the fact that the main action of the play appears in this form, while elaborations appear in other metres and may, therefore, represent additions to or revisions of the parent play.

In all probability, there is present in either one cycle or the other, certain parent plays whose metrical forms are no longer common to both cycles. The determination of such plays is, of course, more or less problematical, but there still remain numerous similarities in structural outline and in verbal agreement which may be noted as indicative of the original identity of the two cycles.

\footnotetext{
Is Mr. Pollard, (Oo. cit. EETSES 71 :intro. xxvi), believes that they "belong to the period when the York plays were being incorporated into the cycle." According to Professor Gayley (ibid. 134, n. 1), they represent early alternatives of York plays, later discarded in York. He also includes the Peregrini in this group.

10 See Miss Smith, ibid. intro. xxy. The play is described thus: ubi Pilatus et alii milites ludebant ad talos fro vestimentis Jesu et pro eis sortes mittebant et ca parciebantur inter se.

17 Professor Hohlfeld (Anglia 11:299 ff.), believes that the Towneley play of the Tolents is an imitation of the condensed accounts now extant in York XXXIV and XXXV, but it seems more likely that the York scenes represent later revisions of the parent play, now extant in part in the Towneley cycle.
} 


\section{CHAPTER IV}

\section{THE SITUATION IN THE INDIVIDUAL PLAYS}

We find in the extant plays of York and Towneley many similarities which bear out the theory of an original identity of the two cycles. Because of probable independent revisions in both cycles after the separation of the two, the similarities naturally differ in degree and kind. Accordingly, nearly every play presents a separate problem. Some plays show practical verbal agreement while certain other plays contain very little parallel phraseology but reveal a close similarity in structural outline. Slight revisions in either one cycle or the other or in both may account for the minor differences discernible in the former group of plays, whereas thorough revisions in either one cycle or the other or in both must be conceded in order to explain the extensive differences occurring in the latter group of plays.

The possibility of independent revisions in both cycles after the separation need offer no difficulties. The large number of stanzaic forms in the English mysteries indicates the existence of early and late plays. ${ }^{1}$ Creizenach $^{2}$ and Chambers ${ }^{3}$ suggest that "to the end of the history of the religious drama, the older types, which it threw out as it evolved, coexisted with the newer ones"; Mr. Davidson" is of the opinion that "a cycle contains the plays, independent or revised, of many writers of different periods and schools," that "it contains the work of many authors, writing on related subjects in different styles and metres. In this work," he continues, "very possibly every generation for two centuries is represented." Professor Hohlfeld ${ }^{5}$ speaks of the revisions through which it is certain both the York and Towneley cycles passed, by which it became possible, he claims, for an original version to be changed to an unrecognizable degree. Mrs. Frank, in her recent article, ${ }^{6}$ concludes that "we have in Towneley as in York a collection of plays each subjected, at least during its formative period, to the vicissitudes of life within its particular craft."

Because of probable changes which both cycles were undergoing all the time, we shall not be surprised if we find in some plays little evidence conclusively indicative of an original identity. In such cases, generally speaking, late metrical forms or extensive elaborations enable us to

${ }_{1}$ Ten Brink, History of Enslish Literature 2:253-87; Pollard, The Towneley Plays EETSES 71 intro. xxiii ff.; Gayley, Representative English Comedies 1:intro. xxiii-xxxi; Plays of Our Forefathers 125-204; Bunzen, Ein Beitrag zar Kritik der Wakefielder Mysterien $7 \mathrm{ff}$; Cady, op, cit. Jour. Eng. Ger. Phil. 10:572 ff.

2 Creizenach, Geschichte des neueren Dramas 1:218.

3 Chambers, The Medieval Stage 2:96; see also ch. xxii.

+ Davidson, op. cit. 172-73.

sohlfeld, op. cit. Anglia 11:256.

- Mrs. Frank, op. cil. Mod. Phil. 15:187. 
identify the plays as revisions in one of the two cycles; nor is it unlikely that certain plays underwent independent revisions in both cycles.

A detailed comparison of the two cycles reveals six groups of plays:

(1) To the first group belong the plays which still remain identical in the two cycles: Pharaoh, the Doctors, On the Way to Calvary, the Harrowing of Hell, the Resurrection, the Last Judgment.

(2) The plays in the second group are those which still retain, in spite of a later revision on the part of either York or Towneley, a similarity in underlying structure, together with isolated passages showing parallel phraseology occasionally retaining even common rhyme words: Joseph's Trouble about Mary, the Magi, the Flight into Egypt, the Massacre of the Innocents, the Incredulity of Thomas, the Creation group, the Prophotic Prologue to the Annunciation, the Shepherds, John the Baptist, Lazarus, the Conspiracy, the Last Supper, the Agony and Betrayal, the Crucifixion and Burial, the Appearance of Jesus to Mary Magdalene, the Peregrini.

(3) The plays in the third group are those which show a similarity in underlying structure, together with isolated passages showing parallel phraseology but without the retention of common rhyme words: ${ }^{7}$ Noah and the Flood, the Annunciation, the Visit to Elizabeth, the Examination before Caiaphas, the Ascension.

(4) The plays in the fourth group are those which show a similarity in underlying structure, but are unaccompanied by passages showing significant or extensive similarities in phraseology: Cain and Abel, Abraham and Isaac, the Condemnation.

(5) The play in the so-called fifth group is the only corresponding play in the two cycles which reveals little similarity in structural outline and no agreement in phraseology, namely, the Purification.

(6) The plays in the sixth group are those which are included in but one of the cycles; (a) plays in Towneley but not in York are: Isaac, Jacob, the Prophetae, Octavian, the Hanging of Judas, the Talents; (b) plays in York but not in Towneley are: the Temptation and the Fall (in part), Expulsion from Paradise, the Nativity, the Temptation, the Transfiguration, the Woman Taken in Adultery, the Entry into Jerusalem, Peter's Denial, the First Trial before Pilate and Pilate's Wife's Dream, the Trial before Herod, the Descent of the Holy Ghost, the Death of Mary, the Appearance of Our Lady to Thomas, the Assumption and Coronation of Our Virgin.

\section{First Group of Plays}

In the first group, we have the plays which, in their extant versions, are still practically identical. In spite of independent revisions through which other plays passed after the separation of the two cycles, these plays retain practically their parent cycle form. They may, therefore,

\footnotetext{
"In isolated cases, a single rhyme word is often retained.
} 
be considered direct evidence of the original identity of the two cycles. The minor differences ${ }^{8}$ do not affect the question; they indicate merely slight changes introduced after York and Towneley became independent cycles.

\section{Second Group of Plays}

In the second group, we have the plays which show a similarity in structural outline and a verbal agreement in isolated passages with the retention of many common rhymes. Later metrical forms, elaboration of details or expansion of phraseology indicate that the play in either York or Towneley, as the case may be, underwent revision. In some cases, the corresponding play in the other cycle may approximately represent the parent play itself.

\section{Joseph's Trouble about Mary}

The play of Joseph's Trouble receives greater elaboration in York and Towneley than in any of the other English cycles. Only York and Towneley include the story of Joseph's marriage ${ }^{9}$ and the testimony of the puellae as to Mary's chastity.

Close similarities in structural outlines and extensive parallels in phraseology $y^{10}$ exist in the York and Towneley plays:

(1) Joseph marvels at Mary's condition. Compare T I1. 155-60 to Y I1. 43-60. Note especially the retention of one common rhyme word, wroght, and the close parallelism of the following lines:

My wyfe., . is grete and she with child.

what has she wroght?

Therfor myin is it noght.
My 3 onge wiffe is with childe full grete.

How pis ping may be wroght, pe childe certis is noght myne.

(2) Joseph, old and weak, bemoans having married so young a woman. Compare T 11. $161-70$ and Y $11.5-23,195-97$. Note especially the retention of the common rhyme words, elde, vnwelde, wyfe, banne.

(3) Joseph, believing himself beguiled, decides to question Mary. Compare T 11. 172-73 and Y 11. 42-43, 65; also T 11. 177-78 and Y 11. 71-74.

som othere has she tane,

she is with chyld, I wote neuer how.

Bot now then wyll I weynd hyr to, And wytt who owe that foode.
I am begiled; how, wate I no5t.

My 3onge wiffe is with childe. .

And why ne walde som yonge man $t a$ her.

Of my wendyng wil $I$ nowe warne,

Neuere pe lees it is myne entente

To aske hir who gate hir pat barne, $3^{i t t}$ wolde I witte fayne or I wente.

- These differences have already been presented in detail by Herttrich, op. cil., Hohlfeld, op. cil. Anglia 11:219 ff., Pollard, op. cil. intro. xv ff.

'In the Hegge plays, the story of Joseph's marriage occurs in Play X, Mary's Betrothment.

$10 \mathrm{Mr}$. Hemingway (Study of the English Nativity Plays, intro. xliii) considers that the verbal similarities noted by Professor Hohlfeld (op. cil. Anglia 11:290) are not significant since they are paralleled in the other cycles, but many agreements not hitherto noticed are presented below, and many of these do not occur in the other cycles. 
(4) Joseph greets Mary and reproaches her. Compare T 11. 179-80 and Y 11. 75,92 .

hayll, mary, and well ye be!

why, bot woman, what chere with the?
All hayle! God be here-inne! (Puellae scene interpolated.) Gramercy, Marie, saie what chere. $158-59,167-68,177-78,188-89,199-200$.

Whos is that chyld

Sir, Goddis and youres

She is with clilde, Whos is't Marie?

Sir, Goddis and youres

(6) Mary protests her innocence. Compare T 11. 203-6 and Y 11. 215-16, with the retention of the rhyme word, filid.

fior fleshly was I neuer fylyd

With synne was I neuer filid

(7) Joseph's incredulity. Compare T 11. 197-202 and Y 11. 169-76, with the retention of the rhyme word, spill; also T $11.167-69$ and $Y 11.195-97$, with the common rhyme word, gane.

The gams fro me ar gane

pase games fra me are gane

(8) Joseph tells the story of his marriage, which he now regrets. Compare T 11. 245-50 and $Y$ 11. 25-30, with the retention of three rhyme words, wand, hande, ment; also $T$ 11. 255-61 and $Y 11.32-34$; T 11. $161-63$ and $Y 11.35-36,21-23$, with the retention of one rhyme word, banne.

Thay gaf ich man a white wand, And bad vs bere them in oure hande, To offre with good intent;

Thay offerd thare yerdys $v p$ in tyde, I wyst not what thay ment.

In my hand it floryshed with blome; Then sayde thay all to me,

That the behovys wed mary the may.

That euer I wed so yong a wyfe,

That bargan may $I$ ban.
For bare-in was ordande

Vn-wedded men sulde stande, $\mathrm{Al}$ 'sembled at asent;

And ilke ane a drye wande

On heght helde in his hand,

And I ne wist what it ment.

Itt florisshed faire, and floures on sprede,

And they saide to me forthy

bat with a wiffe I sulde be wedde.

For bittirly pan may $I$ banne

Itt was to me a bad barganne.

(9) The testimony of the puellae as to Mary's innocence. Compare T 11. 28492 and $\mathrm{Y} 11.108-27$, with the retention of two rhyme words, wight, wight. Joseph refuses to accept their excuses, claiming that Mary's visitor was a man in the likeness of an angel. Compare T 11. 208-14, 294-98 and Y 11. 162-66, 135-37, with the retention of one rhyme word, can.

I askyd ther women who that had done,

And thay me sayde an angell sone, syn that I went from hame;

An angell spake with that wyght,

And no man els, bi day nor nyght,

Thay excusyd hir thus sothly,

To make hir clene of hir foly.
Say, maidens, how es pis?

For trulye her come neuer noman,

Of this swete wight.

And was neuere fro hir day nor nyght,

$\mathrm{Na}$, here come noman in . . .

Saue an Angell.

(10) Joseph goes to the wilderness. Compare T 11. 321-22 and Y 11. 239-40,

(11) The angel appears to Joseph in his sleep and tells him to return home; that Mary's son is conceived of the Holy Ghost. Compare T 11. 333-34 and Y 11, 267-68, with the retention of one rhyme word, gast.

She hase consauyd the holy gast.

Itt is consayued of pe haly gast. 
(12) Repenting, Joseph praises God and asks Mary's forgiveness. Compare T 11. 347-51 and Y 11. 289-93.

ffor thy to hir now wyll I weynde,

A, mary, wyfe, what chere?

The better, sir, that ye ar here.
Me bus pray hir halde me excused, Saie, Marie wiffe, how fares pou? pe bettir, sir for yhou.

Why stande yhe pare? come nere.

(13) Joseph feels "light." Compare T 1. 368 and Y 1. 286.

Professor Hohlfeld's" conclusion that the Towneley play represents a general imitation of the York version with a borrowing of isolated passages is not borne out by a comparison of (1) the metrical situation, (2) the verbal expansion of certain passages in the York play, or (3) the treatment of certain incidents.

(1) The York strophe, rhyming ababccbccb, is a later modification of the simple rime coué in which the Towneley play is composed.

(2) In order to meet the exigencies of a more complicated rhyme scheme, it is apparent that certain York strophes expanded the simpler rime couée stanzas of the Towneley play. Compare especially T $11.155-60$ and $\mathrm{Y} \mathrm{Il.} 43-60 ; \mathrm{T}$ 11. 161-70 and Y 11. $5-24$; T 11. $173-74$ and $Y$ 11. $42-65$; T 11. $177-78$ and $Y$ 11. $71-74$; T $11.179-80$ and $Y$ 11. 75-92; T 11. 284-93 and $Y 11.108-27$; T 11. 349-51 and $Y 11.291-94$.

(3) The York Joseph refuses to be pacified so easily as does the Towneley Joseph by Mary's explanation of her condition. He asks for the parentage of her child no less than six different times, whereas the Towneley Joseph asks but three times. This expansion may be due, in part, to the dramatic presentation of the puellae in York as against the narrative presentation in Towneley. Perhaps, Burton's failure to mention the puellae in the description of the play in the 1415 list $^{12}$ indicates that, as speaking characters, they were not originally present in the York play.

These instances indicate an elaboration by York of the simpler Towneley play, and therefore, the Towneley play is not to be regarded as "an adaptation of an earlier York play," as Professor Gayley ${ }^{13}$ suggests, but as the earlier play itself, or the play nearer the parent-cycle version than the extant York play.

The parallels with true-Coventry, ${ }^{14}$ sometimes corresponding to the extant York play and at other times to the extant Towneley play, may be explained by assuming that the true-Coventry play came into contact either with the parent play itself or with a subsequent revision of it.

\section{The Magi}

In York, the incidents of the Magi or the Coming of the Three Kings and Their Oblation are divided into two separate plays, whereas they are included in a single play in Towneley. Numerous similarities in structural outlines and phraseology exist:

n Hohlfeld, op. cit. Anglia 11:290.

12 The description given the play in Burton's 1415 list (Smith, op. cit. intro. $\mathrm{xx}$ ) is: Maria, Josep volens dimiltere eam, angelus eis loguens st transeant vsque Bedlem.

is Gayley, Plays of Our For fathers 134, n. 1.

14 These parallels have been pointed out by Professor Cady, of. cil, PMLA 24:438 ff. 
(1) Herod, boasting of his beauty and power, orders his messenger to search the realm for miscreants. Compare X P1. XVI, 11. 1-44 and T 11. 1-66.

(2) In the meeting of the three kings and their decision to ride on together, one of the kings prays God to "grant him grace of company" and declares that he will not cease to search until he has discovered the meaning of the star. Compare T 11. 91-92 and Y 11. 19-20 for verbal similarities, with the retention of one rhyme word, companye; also T $11.98-99$ and $\mathrm{Y} 11.22 \cdot 24$, with the retention of two rhyme words, mene, schene; also T 11. $145-48$ and 157 and $Y$ 11. $37-40$; also $Y 11.53-54$ and $T 11.163-64$ with the retention of one rhyme word, fere.

Also I pray the specyally,

Thou graunt me grace of company.

To wyt what this starne may mene,

That has me led, with bemys schene,

lordyngs,

I pray you tell me with good chere wheder ye weynd, on this manere,

And where that ye haue bene:

Good sir, what cuntre cam ye fra?

Now, syrs, syn we ar semled here, I rede we ryde togeder, in fere.
God graunte me happe so pat I myght Haue grace to gete goode companye. With thy sterne schynyng scliene, For certis, I sall noght cease, Tille I witte what it mene.

Sirs, with youre wille, I wolde yoso praye

To telle me some of youre entent,

Whedir ye wende forthe in this waye, And fro what contre $5 \mathrm{e}$ are wente.

$\mathrm{Sir}$, of felashippe are we fayne,

Now sall we wende forth all in feere.

(3) The messenger, returning to court, is reproached for his long absence. Herod's wrath is turned away from him, however, as soon as he learns of the meeting of the three kings, who, guided only by a star, are in search of a new-born child. See T 11. 259-89 and Y 11, 73-96.

(4) Herod inquires into the reasons for the journey and concludes that the three kings must, indeed, be mad. Compare T $11.385-86$ and $\mathrm{Y} 11.106-8$ for verbal similarities, with the retention of two rhyme words, beforne, borne; also T $11.292-94$ and $\mathrm{Y} 11$. 110-13, with the retention of two rhyme words, lad, mad.

lord, when that starne rose ws beforne,

Ther by we knew that chyld was borne.

That new borne lad,

When thare wytt in a sterne shuld be,

I hold thaym mad.
A sterne stod vs byforne,

That makis vs speke and spir Of ane pat is nowe borne.

And certis, unwitty men $3 e$ werre To lepe ouere lande to late a ladde,

Say when lost 3 e hym? ought lange before?

All wyse men will wene se madde.

(5) The prophecies are cited. The verbal similarities in the Balaam and Isaiah passages are close. Compare especially T $11.205-6$ and Y $11.156-60$, with the retention of the two rhyme words, thyng and sprynge.

Certan, balaam spekys of this thyng.

For Balaham saide a starne shulde spring

That of Iacob a starne shall spryng.

Of Jacobe kynde, and pat is Jewes.

Compare also T 11. 417-25 and Y $11.161-65$, with the retention of the following words: Isaia, mayden, shall, bere, Emanuell.

(6) On the pretext of wishing to pay reverence to the child, Herod allows the three kings to pass on, but bids them come again on their way back. Compare T II. 483-88 and Y $11.197-99$ for verbal similarities, with the retention of one rhyme word, tythyng (tythande in $\mathrm{Y}$ ).

Bot com agane with me to leynd,

If it be sothe, this new tythyng,

Som worship wold I do that kyng.
And comes agayne pan me vntill,

And telle me trulye youre tythande, To worshippe hym pat is my will. 
(7) The guiding star disappears from sight and the three kings kneel in prayer begging its return. Upon its reappearance, it stands still above their destination. Compare T 11. 506-8 and Y 11. 221-24 for verbal similarities.

(8) The three kings make their respective offerings. Compare Balthazar's speech, especially, for verbal similarities, T 11. 555-58 and Y 11. 284-88, with the retention of one rhyme word, shalbe. Compare also T 11. 541-42 and Y 1. 277.

In tokyn that thou dede shalbe,

To thy grauyng this myr of me

Resaue the tyll.

hayll be thou,

That boytt of all oure bayll may bryng.
But whan thy dedys ar done to dye is pi dette,

And sen thy body beryed shalbe, This mirre will I giffe to pi grauyng.

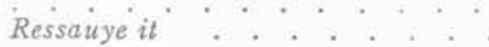

Hayll! barne pat is best oure baylys to bete.

(9) Mary tells of the miraculous birth of her son and gives the three kings her blessings.

(10) Because of weariness, the three kings lie down. An angel appears to them in their sleep and bids them return home another way. This passage is verbally and metrically identical in both plays. Compare T $11.595-606$ and Y 11. 313-24.

Syr curtes kyngys, to me take tent, And turne by tyme or ye be tenyd;

from god his self thus am I sent

To warne you, as youre faythfull freynd,

how herode kyng has malyce ment.

And shapys with shame you for to sheynd;

And so that ye no harmes hent,

By othere ways god wyll ye weynd Into youre awne cuntre:

And if ye ask hym boyn,

ffor this dede that ye have done, youre beyld ay wyll he be.
Nowe curtayse kynges, to me take tent, And turne betyme or $3 e$ be tenyd,

Fro God hym selfe pus am I sent

To warne yow, als youre faithfull frende,

And shapis with shame you for to shende,

And for pat ze non harmes shulde hente, Be othir waies God will ye wende

Euen to youre awne contre.

And yf ze aske hym bone,

Youre beelde ay will he be.

For pis pat pe haue done.
Herowde the kyng has malise ment,

(11) The kings, in gratitude, thank God. Compare T 11. 614-16 and Y 11. 325-28 for verbal similarities, with the retention of one rhyme word, thre.

with hart enterely thank I the,

That thyn angell sent tyll vs thre,

And kend vs so.

(12) The kings separate and each goes his own way.

The following differences may be explained by assuming that the Towneley play, composed in the "Burns" measure, a metre of the parent cycle, ${ }^{15}$ represents the earlier version and the two York plays later revisions $:^{16}$

(1) In conforming to the exigencies of the rhyme scheme of the Northern Septenar stanza, extra lines were apparently inserted by York.

(a) Compare Y 11. 22-24 and T 11. 98-99.

is See above, ch. III, 50 ff.

16 The similarities with true-Coventry, as pointed out by Professor Cady (op. cit. PMLA 24:446 ff.) may be explained, as in the case of Joseph's Trouble (see above, p. 56), by assuming that true-Coventry came into contact with the parent play or a subsequent revision of it. 
With thy sterne schynyng schene, For certis, I sall noght cesse,

Tille I witte what it mene.
To wyt what this starne may mene, That has me led, with bemys shene

(b) Compare Y 11. 106-8 and T 11. 385-86.

A sterne stud vs byforne,

That makis vs speke and spir

lord, when that starne rose vs beforne, Ther by we knew that chyld was borne.

Of ane pat is nowe borne.

(2) In his revision, the York playwright, apparently, made numerous changes in subject-matter. In some cases, he added new material; in other cases, he omitted certain minor details, and in one or two instances even changed the fundamental outline of the plot. Such changes, however, are of slight importance and may be ascribed, for the most part, to one of two principles, either a desire for scriptural accuracy or an attempt at a more realistic portrayal of the incidents.

The additions in the two York plays do not affect the main outlines of the plot; they are merely minor elaborations of essential details common to both cycles.

(a) The York play adds a new character in the person of Herod's son, who appears in connection with the boasting of the soldiers. Herod sings their praises to his youthful son, who, in turn, boasts that he, too, will kill "bad fellows."

(b) When the messenger tells Herod that the three kings are about to arrive at court, Herod, evidently to inspire in them a feeling of awe, arrays himself richly. This is undoubtedly an attempt at a more realistic portrayal.

(c) The three Ycrk kings, in addition to the prophecies quoted, add that Jesus will be king of Judea and indeed king over all people. Perhaps this is an attempt at scriptural accuracy, since the same answer is given in Matthew ${ }^{17}$ and the A pocryphal Gospel of James. ${ }^{18}$

(d) Herod's anger is more pronounced in York than in Towneley.

(e) Herod's invitation to the three kings to return again that way is preceded by the advice of his counsellors bidding him not act deceitfully. After the departure of the kings, Herod rejoices over the trap prepared for them. These elaborations are lacking in Towneley.

(f) An additional character is seen in the maid of the York play, who stands at the door of the stable and bids the kings enter. This is an evident attempt at a more realistic presentation.

The omissions are, for the most part, in line with the simpler scriptural account and do not materially affect the framework of the play.

(a) The York Herod does not impose upon his subjects the worship of Mahomet as does the Towneley Herod.

(b) The three kings in the York play do not go into so much detail in giving the information concerning their names, realms, and purpose in coming, as do the Towneley kings.

(c) York omits the recalling of Balaam's prophecy at the time of the meeting of the kings and transfers it to the questioning by Herod.

(d) The York kings do not discuss the significance of their gifts when they first meet, or the possible influence of astronomy upon the appearance of the guiding star.

(e) The adieux of the Towneley kings are long and elaborate, whereas the farewell speeches of the York kings are short.

Differences are seen in the following instances. Since, however, they are merely minor details with which two of the chief incidents are elaborated, they do not affect the main development of the play.

17 Gospel of Matthew ch. II, 1-12.

it A pocryphal Gospel of James ch. XXI, in Cowper, Apocryphal Gospels. 
(a) The three kings appear before Herod, not at the messenger's command as in Towneley, but of their own free-will, thinking that perhaps Herod can aid them in finding the child.

(b) The prophecies are quoted to Herod by the three kings, instead of by the counsellors from their learned books, as in Towneley. Apparently, this is an attempt at scriptural accuracy, since in the A pocryphal Gospel of James, Herod examines the magi concerning the meaning of the star. ${ }^{10}$

It thus seems probable that the single play which is noted by Burton in his 1415 list $^{20}$ refers to the play now extant in the Towneley cycle, and that the two plays, which are entered in the second Burton list ${ }^{21}$ and referred to in a 1431 record of the Goldsmiths, ${ }^{22}$ refer to the two plays now extant in the York cycle.

It may still be asked how the Towneley play came to include the single Northern Septenar strophe in which the angel makes his appearance and gives the warning to the sleeping kings. According to Professor Hohlfeld's supposition, ${ }^{23}$ it was incorporated by the Towneley playwright who wrote in general imitation of the York play. Since the separation of the two cycles apparently took place while certain plays of the parent cycle were being rewritten in the Northern Septenar metre, ${ }^{24}$ it may be that the isolated Northern Septenar strophe represents an instance in which a single lyrical passage was turned into the newer and more attractive metre before the separation.

\section{The Flight into Egypt}

The Flight into Egypt is closely connected with the Massacre and is usually included as one of its incidents. York and Towneley alone agree in developing it into a separate play and making it precede the Massacre. ${ }^{25}$

Close similarities in structural outlines and phraseology exist:

(1) An angel awakens Joseph who wonders at its sweet voice. Compare T 11. $1-13$ and $Y 11.37-42$.

Awake, Ioseph, and take intent!

Thou ryse, and sleep nomarel

ffor thou shall no harmes hent,

And rew it wonder sare.

Al myghtfull god,

What euer this ment,

so swete of toyn?
Wakyn, Josephl and take ententel

My sawes schall seece thy sorowe sare,

Be noght heuy, pi happe is hentte,

pare-fore I bidde pe slepe no mare.

Al myghtfull lorde, what enere pat mente?

So swete a voyce herde I neuere ayre.

13 Cowper, loc, cit.

${ }^{20}$ See Burton's 1415 list in Smith, op. cit. intro, xxi.

21 See Davies, Municipal Records of the City of York app. 233.

" See Sellers, York Memorandum Book, Surtees Society 125: 123-24; see also intro. xlix.

" Hohifeld, op. cit. Anglia 11:293.

* See above, ch. II, p. 46.

As The same situation is seen in the Beverley list. See Beverley Records, Selden Sociely; Furnivall Miscellany 218; Chambers, op. cit. 2:340. 
(2) The angel bids him not fear; that he is an angel sent to warn him against Herod. Compare T 11. 40, 14-28 and Y 11. 48-62.

Ther of haue thou no drede;

10 Ioseph, it is I,

An angel send to the.

hens behufys the hy,

And take with the mary,

for herode dos to dy

All knaue chyldren, securly, within two yere that be

Of eld,

Where may we beyld?

Tyll egypp shall thou fare.

with all the myght thou may.
Joseph, have bou no drede,

For I am sente to pe,

Gabriell, goddis aungell bright,

Is comen to bidde be flee

With Marie and hir worthy wight:

For Herowde pe kyng gars doo to dede All knave childer in ilke a stede, With zeris twa

pat are of olde

In Egipte shall 5 e beelde,

Tille I witte pe for to saie.

(3) Joseph, grieving for Mary, tells her that they must flee. Compare T 11. 55-8, 62 and Y 11. 84-6, 90. Note especially the following verbal similarities, with the retention of two common rhyme words.

Mary, my darlyng.

Al leyf Ioseph, what chere?

ftor-thi behofes us fle.
Mary, my doughter.

A! leyf Joseph, what chere?

Ther is noght ellis but $u s$ most flee.

(4) Mary can not understand the reason for the flight. Joseph tells her of the angel's message, and she laughs and trembles in her fear. Compare T $11.79-85$ and $Y$ 11. 103-7. Note especially the retention of two rhyme words, care and dare, and the verbal similarity in the line, $I$ lurk and dare (T 1. 83), and $I$ durk, $I$ dare (Y 1. 105).

(5) It is difficult for Mary to understand why she should be deprived of her son. Compare T $11.79-88$ and $Y 11.137-43 ; 67-9 ; 156-58$, with the retention of five rhyme words, sare, ill, spill, care, bare.

(6) Joseph begs Mary to be quiet, saying that they must pack their "gere" immediately. Compare T 11. 114-16; $161 ; 41$ and $\mathrm{Y} 11.147-50$, with the retention of the three rhyme words, be, dynne, wynne and the similar phrases, Wel leue Marie... lat be; leve of thy dynne (Y) and let be thy dyn (T); also T 11. 120-21 and Y 11. 159-60, with the retention of the common rhyme word, gere, and the common use of the following words, $t y t t, p a k$ and oure.

(7) Mary complains about carrying the child. Compare T 11. 129.30; 133 and Y 11. 162-64, with the retention of the one rhyme word, bere, and the common use of the words, God wote.

\section{Certain York passages appear to be verbal expansions of simpler Towne-} ley passages:

A! myghtfull lorde, what euere pat mente?

So swete a voyce herde I neure ayre.

But what arte pou with, steuen so shylle,

bus in my slepe pat spekis me till,

To me appere,

And late me here

What pat pou was? (Y $11,41-47$ )

(1) The lines of the following Towneley passage have been split into separate parts by the York playwright at different points in the presentation:
A! myghtfull god,

What euer this ment, so swete of toyn? ( $\mathrm{T}$ 11. 11-13) 
My son? alas, for care! who may my dollys dyll? wo worth fals herode are! my son why shuld he spyll?

Alas! I lurk and dare!

To slo this barne I bare, what wight in warld had wyll?

his hart shuld be full sare

Sichon for to fare, That neuer yit dyd yll, Ne thoght. (T 11. 79-91)
His foo, allas! what is youre reede,

Wha wolde my dere barne do to dede?

I durk, I dare,

Whoo may my care

Of balis blynne? (Y $11.103-7$ )

Allas! why schulde I tharne

My sone his liffe so sweete,

His harte aught to be ful sare,

On slike a foode hym to forfare,

pat nevir did ill

Him for to spille,

And he ne wate why. (Y 11 13743)

Allas! what ayles hym for to spille

Smale zonge barnes bat neuere did ille

In worde ne dede. (York 11. 67-69)

Alas! Joseph, for care!

Why shuld I forgo hym,

My dere barne pat I bare. (Y 11 . 156-58)

(2) The following York passage shows an expansion in the phraseology of the simpler Towneley passage:

We! leue Marie, do way, late be, I pray pe, leue of thy dynne,

And fande pe furthe for to flee

Away with hyme for to wynne. (Y 11 . $147-50$ )

ffor-thi let be thi dyn And cry.

how shall we theder wyn? (T 11. 11416)

(3) In his command to Mary to make ready their "gere," the York Joseph mentions the articles which he must carry, whereas no mention is made of them in the Towneley play.

bat swete swayne yf pou saue,

Do tyte, pakke same oure gere,

And such smale harnes as we haue.

Ther is noght els to say

bot tytt pak vp oure gere. (T 11 . $120-21)$

Bot god it wote I muste care for all,

For bed and bak,

And all be pakke

pat nedis vnto vs,

It forthers to fene me

pis pakald bere me bus,

Of all I plege and pleyne me. (Y 11. 159-70)

Accordingly, the Towneley play is not to be regarded as an imitation ${ }^{26}$ or adaptation ${ }^{27}$ of an earlier York play, but as the earlier play itself, of which the York play represents a later revision. Thus, the revision easily explains the difference in the conception of Joseph's character in the two plays. Joseph in the York play is not, as Professor Cady states, ${ }^{28}$ entirely different in character from Joseph in the Towneley play; he is not "all sympathy and patience with Mary": fate.

(1) At the beginning of the play, Joseph, weak and weary, bitterly bemoans his

\footnotetext{
"Hohlfeld, op, cit. Anglia 11:293.

" Gayley, Plays of Our Forfathers 134, n. 1.

as Cady, op. cit. PMLA 24:449 ff.
} 
(2) In strophe eleven, he complains about making the trip:

And sertis I dred me sore

To make my smale trippe,

Or tyme pat I come pare.

(3) A certain degree of ill-temper and impatience with Mary appears to be present in the abruptness of the answers vouchsafed by Joseph in strophes 14 and 15. Mary asks where they are going; Joseph replies that he has told her long before: "To Egipte tald I pe lang are." Mary wishes to know where it is, and we can imagine that his reply, "what wate I?" was given impatiently.

(4) In the last strophe, Joseph thanks God for granting him the grace of being strong again, whereas he was so weak before.

Fundamentally, then, the characters of the two Josephs are conceived in the same vein: both are old and weak; both dread the journey and make it unwillingly; both "take it out" on their wives. The denunciations of the one, it is true, are much more bitter than those of the other, but this may be due to the differing conceptions of the two playwrights, ${ }^{29}$ and offers no real objection to the view that the plays were originally identical. The York situation may simply be a part of that general movement, already noted in the Northern Septenar plays, ${ }^{30}$ which sought to give a more scriptural and reverential tone. In accordance with this view, the York playwright would naturally soften the bitter complaints of the Joseph in the parent play, perhaps now represented by Towneley.

\section{Massacre of the Innocents}

The similarities existing between the York and Towneley plays of the Massacre occur not only in structural outlines, as pointed out by Professors Hohlfeld ${ }^{31}$ and $\mathrm{Cady}^{32}$ but also in the selection and arrangement of many details and in verbal agreement in isolated passages.

In plot development, there is but one fundamental difference, that of Herod's attitude when he learns the result of the slaughter. In York, he is angry because of Jesus' escape, but in Towneley, believing that the child has been slain, he rejoices and rewards the soldiers. Except for this difference, the Wakefield author merely elaborates or makes slight additions to incidents presented in less detail in the York play: $:^{33}$

Scene I, the opening scene of vaunting.

(1) The Wakefield author makes the messenger, singing Herod's praises, precede his entrance. The messenger, however, merely repeats or amplifies what the York

20 The same situation is scen in the York and Towneley plays of the Conspiracy, where there is a divergent development of Pilate's character. (See below, p. 78.) In this case, no one questions the probability that the Towneley play represents an earlier York version, which according to my theory formed a part of the parent cycle.

10 See above, ch. II, p. 44 ff.

as Hoblfeld, op. cit. Anglia 11:293.

" Cady, op. cit. PMLA 24:451.

a See Mrs. Frank, op. cit. Mod. Phil. 15:181 ff. 
Herod says in his opening speech. Each one calls for silence and "bowing at his bidding." Note especially T $11.10-16$ and Y $11.6-16$ for verbal similarities, with the retention of five rhyme words, mahowne, towne, bowne, bydyng, lewte.

Herode, the heynd kyng/ by grace of mahowne,

Of Iury, Iowrmontyng/ sternly with crowne,

On lyfe that ar lyfyng/in towre and in towne,

Gracyus you gretyng/ commaundys you be bowne At his bydyng;

luf hym with lewte,

drede hym, that doughty! ze aught to dare and doute,

And lere you lowe to lowte

To me youre louely lorde.

ze awe in felde and towne

To bove at my bidding,

With reuerence and renoune

As fallis for swilk a kyng

pe lordlyest on-lyue

Who her-to is noght bowne,

$B e$ all-myghty mahounde

To dede I schall hym dryue!

(2) The Towneley Herod, not content with the York Herod's assertion that he is lord of every land, gives a long list of the lands over which Herod holds dominion.

(3) The Towneley Herod, as in the York version, calls for silence, and speaking of his anxiety concerning the three kings, asks for tidings, and is told by the messenger of their departure. Compare T 11. 145-47 and Y 11. 100-2 for verbal similarities with the retention of the two rhyme words, past, fast.

Lord, thynk not ill if $I /$ tell you how thay ar past;

I saie for thay are past.

An othere way in hy/ thay soght, and that full fast.

3a, lord, in faitht ful faste.

Compare also T 11. 26-29 and Y 11. 41-45 for slight reminiscences in phraseology.

(4) Herod, thereupon, vents his rage upon the messenger. This scene has been elaborated by the Wakefield author, but there can still be traced an identity in certain words. Compare especially T $11.150,163-64$ and $\mathrm{Y} 11.106,119,125$.

ffy on the dewill! where may I byde?

ffy, losels and lyars! lurdans ilkone!

Tratoures and well wars!....

A! dogges, pe deuell pou spede.

Fy, on pe ladde, pou lyes!

Thou lyes! false traytoure strange.

(5) Towneley elaborates the boasting of the knights as to what they would have done, had they met the three kings.

Scene II, the advice of the counsellors.

(1) Herod calls his council. In Towneley, the Wakefield author adds Herod's command to have his clerks search through Virgil, Homer, and everywhere else, save in legends, also in Boece and other tales, but not in service books, for "this talk of a maiden and a child." The quoting of certain prophecies at this point and Herod's rage because of the information given by them, are also additions.

(2) With the counsellor's suggestion that all knave children under two years of age be killed, the similarity between the two plays is resumed. Compare T 11. 254-56 and $\mathrm{Y}$ 11. 149-54 for verbal similarities, with the retention of the two rhyme words, dede, stede, and the use of the common phrases, all knaue chyldren, ilk a (othere in T) stede, knyghtys...biddis (ordeyn in T), thrug outt bedlam (in Bedlem and all aboute in Y).

(3) Herod, in gratitude, pledges his friendship. Compare T 1. 324, ye shall fynd me freyndly, and Y 1.165 , 3 shall fynde me youre frende. The incident is elaborated in Towneley by Herod's rewarding the counsellor with a gift of land and castles and with the promise of making him pope some day. 
Scene III, the command to kill the children.

(1) The calling of the soldiers and their appearance in their best apparel is an elaboration by the Wakefield author. Especially significant is the actual command given the soldiers, which, fundamental to the plot development of both plays, occurs in similar phraseology. Compare T $11.307-10$ and $Y 11.149-54$, with the retention of the two rhyme words, aboute, clowte.

To bedlem loke ye go/ And all the coste aboute,

All knaue chyldren ye slo/ and lordys, ye shalbe stoute;

Of yeres if they be two/ and within, of all that rowte

On lyfe lyefe none of tho/ that lygys in swedyll clowte.
Gars gadir in grete rowte Youre knyghtis kene be-lyue.

And biddis pam dynge to dede

All knaue childir kepte in clowte,

In Bedlem and all aboute,

To layte in ilke a stede.

The willing acquiescence of the soldiers is another similarity to note.

Scene IV, the killing of the children.

(1) In York, two children are seized simultaneously and killed. In Towneley, three children are seized and killed, but a separate incident is made for each child. The details of the slaughter, however, are unvaried in their repetition, following almost exactly the order of incidents portrayed in the single slaughter scene of the two children in York. The seizure of the children by the soldiers occurs first, followed immediately by the cries of the mothers, the killing of the children, the lamentations of the mothers (each of these incidents is repeated for both the second and third child in Towneley), then the attacking of the soldiers by the infuriated mothers, and the soldiers' threat to tell Herod of the attack.

Scene V, the soldiers' report to Herod upon the results of the slaughter.

The different development, in the two cycles, of the fifth scene, ${ }^{34}$ as well as the other differences noted above, may be explained by assuming that the Towneley play, composed in the characteristic metre of the Wakefield author, represents an expanded revision of the parent play, now extant presumably in York. ${ }^{35}$

\section{The Incredulity of Thomas}

The Incredulity of Thomas is closely connected with the Peregrini and is usually included as one of its incidents, but York and Towneley differ from the other English cycles by developing it into a separate play. Similarities exist not only in structural outlines, as called attention to by Professor Cady, ${ }^{36}$ but also in the use of minor details and parallel phraseology in isolated passages:

(1) The assembled disciples mourn Jesus' crucifixion.

(2) Jesus appears, but vanishes immediately.

"See above, p. 63.

is Even the true-Coventry play, believed to have the same liturgical source as the York and Towneley plays (Cady, op. cit. PMLA 24:451-f.) differs from the outline followed by them: (1) the preliminary scene of Herod's vaunting is not given; (2) Herod calls no council, but suggests the slaughter himself: (3) the soldiers remonstrate against the brutal order; (4) the lullabies of the mothers are added; (5) Herod, hearing of the flight, starts out in pursuit.

se Cady, op. cil. PMLA 24:464 ff. 
(3) Jesus reappears, tells the disciples not to fear him, but to feel his flesh and bones, so that they may be convinced that he is not a spirit. Compare T 1.96 and $Y$ 11. 31-32 for verbal similarities, also T 11. 94-99 and Y 11. 46-48, 55-60, with the retention of five rhyme words, se, tre, gone, bone, none, and other similar phrases.

peasse emangys you ever ichon!

it is $I$, drede you noght.

Thou grauntt vs for to se

The self body and the same/

the which that died on tre.

That was wonte with you to gone/

and dere with dede you boght.

Grope and fele flesh and bone/

Sich thyng has goost none;
Pees vnto yowe euermore myght be, Drede you nozt, for I am hee.

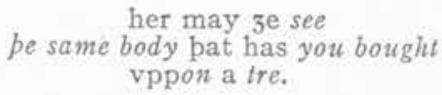

For yowe pusgatis panne haue I gone, Folous me grathely euerilkone, And se pat I have flessh and bone, For so ne has sperite none.

(4) Jesus tells the disciples to look at his wounds. Compare T 11, 100-3 and Y 11. 49-54, with the retention of two rhyme words, meet and feet.

My rysyng fro dede to lyfe/

shall no man agane moytt;

Behold my woundes fyfe/

thurgh handys, syde, and foytt. pat I am comen 3 ou here to mete, Behald and se myn handis and feete, And grathly gropes my woundes wete.

(5) Jesus calls for meat and is brought honeycomb and fish. Blessing them, he bids the disciples eat with him.

(6) Jesus tells of his crucifixion.

(7) Jesus gives the disciples the power to bind and loose. Compare T 11. 148-51 and $\mathrm{Y}$ 11. 89-96, with the retention of three rhyme words, me, pauste, be, and the use of other similar phrases.

The grace of the holy gost to wyn/ resaue here at me;

The which shall neuer blyn/

I gif you here pausie;

whom in erth ye lowse of syn/

in heuen lowsyd shall be,

And whom in erthe ye bynd therin/

In heuen bonden be he.

\section{And vnto 5 ou pe holy goste Releffe yow here.}

Beis now trewe and trowes in me,

And here $I$ graunte youe in youre poste, Whome bat ze bynde bounden schall be

And whome pat ze lesid losed schalbe Euer more in hetuene. Jesus.

(8) Thomas, mourning outside the chamber door, recalls the pains suffered by

(9) Thomas enters the chamber where the disciples are assembled, and Peter tells him that they have seen Jesus.

(10) Thomas is incredulous, but the disciples insist that Jesus rose the third day and that he showed them his wounds. Compare T 11. 188-90 and Y 11. 139-41, with the retention of two rhyme words, lyue and fyue, and the use of the common phrase, his woundes fyue. Thomas believes that they were deluded by a spirit, but the disciples declare that no ghost could possess the flesh and bones which they actually felt. Compare T 11. 220-22 and Y 11. 151-56, with the retention of two rhyme words, bone and none, and the use of similar phrases.

Thomas, vnto the anone/

herto answere I will;

Man has both flesh and bone/

hu, hyde, and hore thertill;

sich thyng has goost none/

thomas, lo, here thi skyll.
Nay Thomas, pou haste misgone,

For-why he bad vs euerilkon

To grope hym grathely, bloode and bone

And flessh to feele,

Such thyngis, Thomas, hase sperit none, pat wote 3 e wele. 
Yet again, the disciples insist that they saw and felt the wounds. Compare T 11. 27679 and Y $11,163-68$ for verbal similarities, with the retention of three rhyme words, seene, mene, betwene.

ffor we say that we haue sene/ thou holdys vs wars then woode; Thesu lyfyng stod vs betwene/

I say ye wote neuer what ye mene/
Are schalle I trowe no tales betwene. Thomas, pat wounde haue we seene.

$3^{2}$, $3 e$ wotte neuere what $3 e$ mene, youre witte it wantis.

Nevertheless, Thomas still doubts, saying that he will not be convinced until he, himself, has felt the wounds.

(11) Jesus appears a third time and bids Thomas feel his side.

(12) Thomas believes and cries for mercy. Compare T 11. 316-19 and Y 11. 18186 for verbal similarities, with the retention of three rhyme words, me, se, the.

Mercy, ihesu, rew on me/

my hande is blody of thi blodel

Mercy, ihesu, for I se/

Mercy, ihesu, I pray thel
Mi lorde, my god, full wele is me,

A! blode of price! blessid mote pou be, Mankynd in erth, behold and see

Mercy, nowe lorde ax i the.

(13) Jesus tells Thomas that they who have not seen and yet believe are more blessed than they who have to see in order to believe.

The York play, composed in a metre of the parent cycle, the "Burns" strophe, probably represents the parent play, of which the extant Towneley play is a later revision. Thus, the differences between the two plays may be explained.

(1) The Towneley play not only includes all of the incidents contained in York but adds to them:

(a) Peter's remorse over his denial of Jesus is added.

(b) After Jesus has given the disciples the power to bind and loose, contained in both versions, the Towneley apostles express a desire for greater stability of thought, and exult because of Jesus' triumph over death.

(c) Additional arguments to convince Thomas are given in Towneley.

(d) The Towneley Thomas makes a greater show of repentance. He even flings away his staff, hat, mantle, gay girdle, silk purse, and coat, in order that he may the sooner gain Jesus' mercy.

(e) The incident at the beginning of the play, where Mary Magdalene appears with the news of the Resurrection, may also be an addition, but since it occurs in the rime couée, it is more likely that it represents a part of the parent cycle, perhaps at an earlier stage than that represented by the "Burns" measure.

(2) The further elaboration of the Towneley play may also be seen in the verbal expansion of certain strophes.

(a) Compare Y 11. 49-50 and T 11. 100-1.

pat I am comen 3 ou here to mete, Behalde and se myn handis and feete.

My rysyng fro dede to lyfe/ shall no man agane moytt; Behold my woundes fyfe/ thurgh handys, syde, and foytt.

(b) Compare Y 11, 91-93 and T 11. 148-51. 
Beis now trewe and trowes in me, And here I graunte youe in youre poste,

Whome pat 3 e bynde bounden schall be. resaue here at me;

The which shall neuer blyn/

I gif you here pauste;

Whom in erth ye lowse of syn/ in heuen lowsyd shall be.

(c) Compare Y 11. 163-65 and T 11. 276-79.

Are schalle I trowe no tales betwene. Thomas, pat wounde haue we seene. $3 \mathrm{a}, 3 \mathrm{e}$ wotte neure what ze mene. ffor we say that we haue sene thou holdys vs wars then woode; Ihesu lyfyng stod vs betwene/ oure lord that with us yode.

I say ye wote neuer what ye mene.

\section{The Creation Group}

The Fall of the Angels.- Structural and verbal similarities exist between the York and Towneley plays of the Fall of the Angels:

(1) The introduction by God. Compare especially T 11. 1, 7, 2, 8 and Y 11. 1, 2,4, 8 for verbal similarities, with the retention of two rhyme words, begynnyng and endyng.

Ego sum alpha et 0 .

I am without begynnyng.

I am the first, the last also.

My godhede hath none endyng.
Ego sum Alpha et $\mathrm{O}$, vita via

I am gracyus and grete, god withoutyn begynnyng.

I am formaste and fyrste, . . .

Vne[n]dande withoutyn any endyng.

(2) God decides to create heaven, earth, and the angels. Compare T11. 13-18 and Y 11. 9-19 for verbal similarities, with the retention of four rhyme words, noght, will, fulfill, might.

All maner thyng is in my thoght,

Withoutten me ther may be noght, hit shall be done after my will,

that I haue thoght I shall fulfill And manteyn with my might.
Sen I am maker vnmade, and most so of mighte,

And all sall be made euen of noghte.

But onely pe worthely warke of $m y$ wyll

In my sprete sall enspyre pe mighte of me,

And in pe fyrste, faythely, my thoghts to fulfyll.

(3) Lucifer is made the chief of the angels. Compare T 11.71-72 and Y 1. 36 for verbal similarities.

He may well hight lucifere, ffor lufly light that he doth bere.

I name pe for Lucifer, als bearer of lyghte.

(4) The cherubim praise God for the work of creation. Compare T 11. 67-76 and Y 11. 41-44 for verbal similarities, with the retention of two rhyme words, mighte and noghte.

Lord, thou art full mych of might,

that has maide lucifer so bright;

We lofe the, lord, with all oure thoght, that sich thyng can make of noght.
A! mercyfull maker, full mekill es pi mighte,

pat all this warke at a worde worthely has wroghte,

Ay loved be pat lufly lorde of his lighte,

That vs thus mighty has made, pat nowe was righte noghte. 
(5) Lucifer boasts of his strength and beauty. Compare T $11.83-96$ and Y 11. 49-83, also Play VI, 1. 7 for verbal similarities.

of me commys all this light, this gam and all this gle;

My myrth is most of all.
All the myrthe pat es made es markide in me,

Fro thaym is loste bope game and glee

$\dot{\text { I }}$ am so mightyly made $\dot{m} \dot{y}$ mirth may noghte mys.

(6) Still boasting, Lucifer seats himself on God's throne.

(7) Without apparent intervention, Lucifer falls.

(8) The devils cry out in terror as they fall. ${ }^{37}$

(9) The devils lament in hell and reproach Lucifer as the cause of their fall.

These similarities, as well as certain additions and omissions made in common by York and Towneley, may be explained by assuming that the extant Towneley play represents the parent play and that the extant York play represents a later revision of it.

(1) Both the York and Towneley plays provide for the creation of the earth before the fall of the angels. Although the developments of the two scenes do not resemble each other, the difference may be adequately explained by the later revision of the York play. The mention in York of the creation of earth with that of heaven seems to be a reminiscence of the detailed account of the creation of earth day by day, given at the same point in the supposed parent play, now preserved presumably in the Towneley cycle.

(2) The confusion in the York play, at the point where God grants to his angels not only heaven but earth also, and this before the creation of earth, is to be regarded as an indication of its earlier position in the parent cycle, which in spite of the attempt on the part of the York playwright to conform to the correct chronology of the incidents, was carried over into his revision. See 11. 22-30.

(3) The failure of God to appear at the time of Lucifer's defiance in order to give the command to fall is in keeping with the Genesis and Exodus account, ${ }^{38}$ and is therefore another indication that York in its revision still made use of the parent play, preserved in Towneley.

(4) The crying out of the devils as they fall assumes significance because of its absence in the other English plays. The actual crying out of the devils in the York play represents a more developed stage in dramatic technique than the stage directions of the Towneley play.

(5) One York passage appears to be an expansion of one of the Towneley couplets. Compare T $11.7-8$ and $\mathrm{Y} 11.1-8$.

I am without begynnyng,

My godhede hath none endyng.
I am gracyus and grete, god withoutyn begynnyng,

I am maker vnmade, all mighte es in me,

I amlyfe and way vnto welth wynnyng,

I am formaste and fyrste, als I bid sall it be.

My blyssyng o ble sall be blendyng,

And heldand fro harme to be hydande, My body in blys ay abydande

Vne[n]dande withoutyn any endyng.

"Merely a stage direction in Towneley, Pollard's edition, EETSES 71:5.

a Genesis and Exodus (ed. Morris) EETS 7;12. 
The Creation to the Fifth Day.-Among the English cycles, little or no elaboration of incidents is seen in the Creation to the Fifth Day. The same incidents are treated in all, and York, Towneley, and Chester agree in isolated phrases. ${ }^{32}$

The similarity is somewhat closer in York and Towneley, however.

(1) The phraseology in two passages is closer than in Chester:

(1) Compare T 11. 40-41, Y 11. 30-32, Ch p. 21, where the two rhyme words, be and see, are common to York and Towneley, but do not occur in Chester.

(2) Compare T 11. 52-3, Y 11. 7-8 (Play III), Ch p. 21, where one rhyme word, night, is common to York and Towneley, but not used in Chester.

(2) York and Towneley mention two details not found in Chester:

(1) In York and Towneley, God remarks upon the work which he has undertaken: in Towneley, he expresses his satisfaction, (1. 42); in York, he speaks of the difficulty of the work (1.27).

(2) In York and Towneley, God blesses his work when all is finished. See T 11. $59-60$ and $\mathrm{Y} 1.86$.

In $m y$ blyssyng, wax now ye;

This is the fyft day.

My blyssyng haue 3 e all; the fift day endyd $e s$.

These similarities, slight as they are, may indicate that York and Towneley were originally identical, and the agreements and disagreements with Chester may be explained by assuming that Chester came into contact with the parent play.

Creation of Adam and Eve and Their Establishment in Paradise.Because of close connection in subject-matter, the Creation of Adam and Eve and their Establishment in Paradise will be considered together. Certain verbal parallels between the York and Towneley plays may be pointed out:

(1) Compare T 11. 165-66 and Y P1. III, 11. 21-23 for verbal similarities, with the retention of the two rhyme words, liknes and less.

now make we man to oure liknes. that shall be keper of more \& les.
To keepe pis worlde bothe more and lesse

A skylfull beeste pan will y make, Aftir my shappe and my likeness.

(2) Compare T 11. 174-81 and Y Pl. IV, 11. 1-12 for verbal reminiscences, with the retention of the three rhyme words, wise, paradise, place.

I gif the witt, I gif the strenght, of all thou sees, of brede \& lengthe; thou shall be wonder wise, Myrth and Ioy to have at will, All thi likyng to fulfill, and dwell in paradise.

This I make thi wonnyng playce, fful of myrth and of solace.
Adam and Eve, this is the place

That I haue graunte you of my grace To haue your wonnyng in; Erbes, spyce, frute on tree, Beastes, fewles, all that ye see, Shall bowe to you, more and myn.

This place hight paradyce, Here shall your joys begynne, And yf that ye be wyse, Frome thys tharr ye never twynne. All your wyll here shall ye have.

s" Similarities occur in T 11. 31-32, Y 11. 19-20, Ch p. 20; T 11. 37-39, Y 11. 27-29, Ch p. 21; T Il. 43-45, Y 11. 33-36, Ch p. 21. 
(3) Compare T 11. 198-99 and Y P1. IV, 1l. 83-84 for verbal similarities, with the retention of two rhyme words, wife and life.

Heris thou adam, and ene thi wife,

I forbede you the tre of life.
Thys tre that beres the Fruyte of Lyfe, Luke nother thowe nor Eve thy wyf.

Moreover, York and Towneley repeat the command not to eat of the tree of life. This repetition is not necessary to the action, and since it does not occur in the other English plays, its presence, together with the verbal parallels, may be regarded as significant.

The Temptation.--Lucifer's speech, in which he plans to betray mankind, occurring just before the gap in Towneley and at the beginning of the fifth play in York, seems to indicate a further similarity. The gap in the manuscript occurs in the midst of the speech where Lucifer states his intention of betraying man. Both Professor Hohlfeld ${ }^{40}$ and $\mathrm{Mr}$. Pollard ${ }^{41}$ think that this formed the beginning of the temptation, which together with the expulsion, they suggest, originally formed a part of the play.

The similarities in details and phraseology between the Creation plays of the two cycles may best be accounted for by supposing that Towneley preserves the text of the parent play and that York represents later revisions of it. The difference in the order of incidents as presented in Towneley, where the Fall of the Angels is embedded in the midst of the Creation scenes, and in York, where it precedes the Creation scenes, may at first appear to contradict this assumption, but it is fully explained by the fact that Towneley gives the arrangement of earlier vernacular literature, such as the Middle English Genesis and Exodus ${ }^{42}$ and Comestor's Historia Scholastica, ${ }^{43}$ and that the York play follows the usual order of cyclical plays. The divergence between the two cycles, therefore, becomes not an inconsistency, ${ }^{4}$ but a logical development entirely consistent with the York practice of revising according to Scripture and chronology. ${ }^{45}$ Moreover, Towneley represents an earlier stage in cyclical development than York, since it includes in one play and composed in two simple metres, the couplet, and the rime couée, incidents which are expanded by York into six plays, some of which are written in complicated stanzaic forms.

\section{Prophetic Prologue to the Annunciation}

Similarities in details and phraseology occur in the York and Towneley Prologues to the Annunciation:

40 Hohlfeld, op. cit. Anglia 11:287.

"Pollard, op. cit. EETSES 71:9, n.

as Morris, loc. cit.

w Comestor, Historia Scholastica, Migne Pat, xcviii.

"So considered by Professor Cady, op. cit. Mod. Phil. 10:597, who concluded that the plays "were evidently added to each of these two cycles at a period when they were no longer connected."

s See above, ch. II, p. 44. 
(1) Adam's fall is reviewed by an expositor. Adam, in innocence, was placed in paradise to enjoy it, but upon sinning was expelled and forced to suffer sorrow in hell. After a long period, however, God is willing to grant him grace. Compare T 11. 1-20 and Y $11.1-12$ for verbal similarities, noting especially T $11.7,11,8$ and Y 11 . $6,7,11$, and 12 .

Then I hym put out of that place.

ffor he has boght his syn full sore.

Bot yit, I myn, I hight hym grace.
And was putte oute fro paradys.

And sithen what sorouse sor warre sene.

Tille god graunted pam grace Of helpe, als he hadde hyght.

(2) In order to deceive the fiend, God decides to have his Son assume manhood through a maiden of Abraham's line, thus fulfilling the promise made in olden days to Abraham. Compare T 11. 30, 35-36 and Y 11. 20-24 for verbal similarities.

(3) Other prophecies besides that of Isaiah are mentioned. Some of the York prophecies are found paralleled in the Towneley cycle, not in the prologue to the Annunciation, as we should expect to find, but in the single quatrains at the beginning of the Doctor's play. Compare T 11. 1-4 and Y 11. 61-64.

Compare also T $11.9-12$ and $\mathrm{Y} 11.13-16$ for verbal similarities, with the retention of two rhyme words, neven and steuen.

Masters, youre resons ar right good,

And wonderfull to neven,

Yit fynde I more by abacuk;

Syrs, lysten a whyle vnto my steuen. ban is it nedfull for to neven,

How prophettis all goddis counsailes kende,

Als prophet Amos in his steuen,

Lered whils he in his liffe gun lende.

Compare also T 11. $13-21$ and $Y$ 1l. $73-9$ for verbal similarities.

Oure bayll, he says, shall turn to boytt, her-afterward som day;

A wande shall spryng fro Iesse roytt,-

The certan sothe thus can he say,-

And of that wande shall spryng a floure,

And therapon shall rest and lyght

The holy ghost, full mych of myght.
More of pis maiden me meves [he], This prophett sais for oure socoure, A wande sall brede of Jesse boure; And of pis same also sais hee,

Vpponne bat wande sall springe $a$ flowre,

Wher-on pe haly gast sall be.

(4) Gabriel is sent to the virgin Mary. Compare T 11. 53-60, 76 and Y 11. 135-41 for verbal similarities, with the retention of two rhyme words, Galile and be (by in T).

Ryse vp, gabriell, and weynd vnto a maydn that is heynd, To nazareth in galilee,

Ther she dwellys in that cytee.

To a man of dauid house,

Ioseph also he is namyd by,

Grayth the gabriell, and weynd.
'Fro God in heuen es sent,' sais he, 'An aungell is named Gabriell To Nasareth in Galale,

Where pan a mayden mylde gon dwell, pat with Joseph suld wedded be.'

To god his grace pan grayd.

Undoubtedly, the terse, narrative account in the Towneley couplets represents, in part, the parent play, and the Northern Septenar redaction in York ${ }^{46}$ a later revision of it. In the Towneley Prologue, the expositor

"Hemingway (English Nativily Plays intro, xliv) suggests a closer similarity between the Towneley Prologue and the Prologue to the Hegge play in which the Daughters of God plead the cause of man than Prologue and the Prologuer examination. He does not consider the parallel in the York cycle. Nor are the similarities with true-Coventry (Cady, op. cil. PMLA 24:435) as close as those between York and Towneley. 
merely mentions the names of the prophets, whereas the actual prophecies are given in York. The revision also explains the additional prophetic material in the York play and the difference in the list of prophets cited.

\section{The Shepherds}

Common rhymes are found in the following passages of the York, Towneley, and true-Coventry plays of the Shepherds:

(1) Compare T XIII, 693-95, Y 73-75, TC $300-1$ for verbal similarities, with the retention of two rhyme words, borne and morne.

beforne,

Thay desyryd to haue sene this chylde that is borne. A babe in Bedlem shulde be
borne,

Of whom pan spake oure prophicie trewe,

And bad us mete hym pare pis morne.

(2) Compare T XIII, 665-66, Y 129-31 for verbal similarities with the retention of two rhyme words, gang and lang.

To bedlem he bad that we shuld gang,

I am full fard that we tary to lang.
God graunte vs levyng lange, And go we hame agayne, And make mirthe as we gange.

(3) Compare T XIII 659, Y 56, TC 268 for verbal similarities with the retention of the rhyme word, emong.

ffor to syng vs emong.

Itt menes some meruayle vs myrth and solas ys cum hus emang. among.

(4) Compare T XII 341 , TC $247-50$ for verbal similarities with the retention of two rhyme words, told and wold.

Also Isay says oure faders vs told,

That a vyrgyn shuld pas of Iesse, that wold

Bryng furth
. now ys cum the tyme that old fathers hath told

A chyld of meydyn borne be he wold.

(5) Compare T XIII 710-11, TC $307-9$ for verbal similarities with the retention of two rhyme words, mylde and chylde.

...... hayll, yong child!

hayll, maker, as I meyne,

of a madyn so mylde!
Hayle, mayde-modur and wyff soo myld!
I have nothyng to present with thi chylde.

(6) Compare Y 93, TC 315 for verbal similarities with the retention of the rhyme word, layde.

Loo! whare pat lorde is layde.

For in a pore loggyn here art thow
leyde.

(7) Compare Y 40-2, TC $243-5$ for verbal similarities with the retention of the rhyme word, sight.

Steppe furth and stande by me right,

And tell me ban

Yf pou sawe euere swilke a sight.

Whatt thyng ys yondur thatt schynith soo bryght?

Yett sawe I neyuer soche a syght. 
Professor Cady ascribes such passages of verbal similarity to the use of a common liturgical source, ${ }^{47}$ but the presence of common rhymes seems rather to indicate the existence of a parent play, of which perhaps the three extant plays represent later revisions. Certainly, the two Towneley plays, which occur in the characteristic metre of the Wakefield author, were composed after the separation of the two cycles, ${ }^{48}$ as perhaps also the York play in the Northern Septenar. ${ }^{49}$ Accordingly, the numerous differences in these plays are adequately explained.

York and Towneley further agree in two minor details wherein trueCoventry differs: (1) in the emphasis placed upon the citation of prophecies and (2) in the mention of a "cracked" voice ${ }^{50}$ as the reason for the shepherd's failure in imitating the angels' voices.

\section{John the Baptist}

A similarity between the York and Towneley plays of John the Baptist, contrary to Professor Hohlfeld's conclusion ${ }^{51}$ that none existed, becomes apparent when the two plays are compared, as in the following outline, ${ }^{52}$ with the simpler Ludus Coventriae play.

(1). Since John in Ludus Coventriae does not mention any of the following points in his opening speech, their occurrence in both York and Towneley appears significant, especially in the light of certain verbal similarities.

(a) The people have wondered as to the possibility of John's being the Christ (Towneley) or a prophet (York).

(b) John says that he can use only water for baptism, but that Jesus can use the Holy Ghost. Compare T 11. 41-46 and Y $11.8-14$ for verbal similarities, with the retention of one rhyme word, gaste.

In water clere then baptyse $I$

The pepyll that ar in this coste;

Bot he shall do more myghtely,

And baptyse in the holy goost.
When $I$ have, lord, in the name of the Baptiste pe folke in watir clere, pan haue I saide pat aftir me

He schali giffe baptyme more entire in fire and gaste.

(c) John says that he is only a messenger, a forerunner of Christ; that his purpose is to urge man to prepare for the coming of Jesus. Compare T 11. 25-28 and Y 11 . 15-18 for verbal similarities,

I am send bot messyngere

And as forgangere am I send.

pus am I comen in message right,

And be fore-reyner in certayne.

47 Cady, op. cit. PMLA 24:444 f.

"See below, p. 101.

"See above, ch. II, p. 30 ff.

20 Cf. T XIII, 11. 656-59 and Y 11. 67-68.

s1 Hohlfeld, op. cil. Anglia 11:295.

s2 The play of John the Baptist does not occur in Chester. 
(2) In both York and Towneley, an angel ${ }^{\text {ss }}$ tells John of the coming of Jesus for baptism, whereas, in Ludus Coventriae, no angel appears.

(3) John's fear and trembling in baptizing Jesus appear only in York and Towneley. Compare T 11. 181-84 and Y 11. 141-47 for verbal similarities, with the retention of two rhyme words, stande and drede.

I tremyll and I whake for drede!

I dar not towche the with my hande,

Abyde, my lord, and by me stand.
A! lorde, I trymble per I stande, For the to touche haue I grete drede, Now helpe me lorde, : : :

(4) The actual descent of the Holy Ghost and God's proclamation from the clouds occur in Ludus Coventriae, but not in York or Towneley.

Mr. Pollard ${ }^{54}$ suggests that the Towneley play belonged to the "period when the York plays were being incorporated into the cycle," and Professor Gayley ${ }^{55}$ believes it was based upon an early alternative of the York play, later discarded. Professor Gayley's conclusion may be true, but metrical and stylistic similarities of the Towneley play and certain York plays, such as the Building of the Ark and the Last Judgment, may indicate that the extant Towneley play itself represents the parent version, of which the York play is a revision. If this be the case, then York, in its revision, as in the case of the Northern Septenar plays, ${ }^{56}$ omitted incidents which did not have a scriptural basis, especially those which were derived from vernacular literature.

(1) The strophe in which John apostrophizes Jesus' mother as the empress of hell was derived from a vernacular lyric. ${ }^{37}$

(2) John believes that the angel's refusal to allow him to meet Jesus signifies the necessity of having children brought to church for baptism. This is the didactic tone and manner of the homilies.

(3) Jesus' presentation of a lamb to John, as a charm against adversity, is probably to be ascribed to a vernacular source.

Or it may be, that the simpler York play is the parent version and that the expanded Towneley play is a revision of it.

\section{Lazarus}

Although the York, Towneley, and Chester plays of the Raising of Lazarus show many points of similarity, the relation between York and Towneley, in the portions unaffected by the gap in the York manuscript, ${ }^{58}$ is closer:

\footnotetext{
"One angel appears in York, but two in Towneley.

"Pollard, o p. cit. EETSES 71 intro, xxvi.

u Gayley, Plays of Our Forefathers 134, n. 1.

$M$ See above, ch. II, p. $43 \mathrm{ff}$.

" See Taylor, The Middle English Religious Lyric Mod. Phil. 5:20.

"Smith, op. cil. 199.
} 
(1) Jesustells the disciples that they will go to Bethany, but the apostles, fearing for his life, object. Compare T 11, 7-10, 18, Y 11. 117-22, Ch p. 225 for verbal similarities, with the retention of three common rhymes, stede, dede, agane, in York and Towneley, and one, agane, in Chester.

I red not that ye thider go, A!lorde, pou wote wele ilke Master, righte well thou The Iues halden you for a tyde,

I red ye com not in that nere, stede, To stone pe vnto dede,
Or putte to pereles payne, may see

The Jewes woulde have

ffor if ye do then be ye dede. And pou to pat same siede

stoned thee, And yett thou will againe.

Will thou now go thider Covaites to gangeagayne. agane?

(2) Jesus tells the disciples that Lazarus sleeps and they, considering this a sign of recovery, suggest that they do not disturb him. Compare T 11. 19-21, Y 11. 131-34, and $\mathrm{Ch}$ p. 226 for verbal similarities.

herkyn, breder, and takys And to 3 ou saie I more, Lazarre, my frende, is sleap-
kepe; lazare oure freynde is fallyn Slepes nowe, and I therfore Theidder we muste be on slepe;

The way till hym now will

With sou to hym will goinge. we take.

(3) When Jesus informs the disciples that Lazarus is dead, they decide to go with him. Compare T 11, 29-30, Y 11. 137-39 for verbal similarities, with the retention of two rhyme words, stede and dede. Although the same incident is presented in Chester, no verbal parallels with York or Towneley occur.

Ne slepe may stand hym in no stede,

I saie to $30 u$, Lazare is dede,

I say you sekerly he is dede.

And for sou all grete joie I haue, je wote I was noght in pat stede.

(4) Martha reproaches Jesus for not being present during her brother's illness, but he assures her that Lazarus will rise.

(5) Martha thinks Jesus means at Doomsday, but he assures her that he is the "resurrection and the life."

(6) Jesus sends Martha to fetch Mary, who, lamenting, tells him of their sorrow.

(7) Mary leads Jesus to the grave, telling him that Lazarus has been buried four days.

(8) Jesus prays to God and bids Lazarus step forth.

(9) Lazarus, in gratitude, praises Jesus. ${ }^{69}$

Certain expansions in phraseology and certain additions in material conforming to scriptural accounts lead to the conclusion that the Northern Septenar strophes of the York play are a revision of the Towneley couplets:

As evidence of the metrical expansion by York in conforming the couplets to the more complicated rhyme scheme of the Northern Septenar:

(1) T 11. 9-10 and Y 11. 119-21.

I red ye com not in that stede, ffor if ye do then be ye dede.

(2) T 11. 29-30 and Y 11. 137-40.

To stone pe vnto dede, Or putte to pereles payne:And pou to pat same stede.

"The gap in the York manuscript covers points 4-7 inclusive. 
Ne slepe may stand hym in no stede, I say you sekerly he is dede.
I saie to 3 ou, Lazare is dede, And for 3 ou all grete joie I haue, 5e wote I was noght in pat stede.

As evidence of additions in subject-matter by York:

(1) In the beginning of the play, Martha and Mary, in distress over their brother's death, send for Jesus, who replies that the illness of Lazarus is not deadly but for the glorification of God's Son. This addition may have been made for dramatic completeness, or perhaps for the sake of scriptural fidelity.

(2) The apostles' fear for Jesus' life is elaborated in York by Jesus' remark that they must work while it is still light.

(3) In accordance with the principles underlying all Northern Septenar plays, which excluded any derogatory remarks concerning the Deity, the York Martha, instead of reproaching Jesus for his delay, praises him at his entrance.

(4) At the close of the play, either omitted from the Towneley version because of the addition of the more interesting Wakefield material, or included in the York version because of a desire for scriptural accuracy, the York Martha and Mary thank Jesus, and he, blessing them, leaves for Jerusalem.

At the same time, it should be noted that the Towneley strophes in double quatrains and those rhyming ababababccedcd are probably later additions in that cycle to the original or parent play in couplets. In the York version, Lazarus tells about being buried for four days and testifies to the power of the Son of God, asserting that all who trust in him will not die. ${ }^{60}$ Upon such a basis, present presumably in the parent play, Towneley shows an extensive elaboration. Lazarus assures the people, in double quatrains, ${ }^{61}$ that no wonder can be greater than his resurrection; that he has, indeed, been brought back from hell. At this point, the metre changes to that rhyming ababababcccdcd, and in a style closely resembling that of the Wakefield author, ${ }^{62}$ Lazarus asserts that not the mightiest on earth, neither king nor knight, can escape death, and that in spite of their gay clothes, their flesh will be eaten away. Changing back to the double quatrains, he begs the people to amend their lives while they may, and then returning to the longer strophe form, he assures them that he has seen and heard many a marvel, and that they should take warning from his sufferings. The play closes with his cry to God for protection. These exhortations point to a later lyrical insertion, ${ }^{63}$ and do not in any way affect the fundamental structure of the play.

\section{The Conspiracy}

The Towneley Conspiracio corresponds to three plays in the York cycle, the Conspiracy proper, the Last Supper, and the Agony and Betrayal. In order to facilitate the necessary discussion and explanation of details, the Towneley play will be divided into three portions corresponding to the three play divisions of the York cycle.

\footnotetext{
00 York Play XXIV, 11. 186-97.

61. Towneley Play XXXI, 11. 103-10.

62 Bunzen op. cil. 15, suggests that the play was revised by the Wakefield author.

s See Taylor, op. cil. Mod. Phil. 5:30, 32.
} 
The Conspiracy Proper.- Similarities in the structural outlines and phraseology of the York and Towneley plays of the Conspiracy proper have already been presented ${ }^{64}$ and may be regarded as evidence of the original identity of the two plays. ${ }^{65}$ In fact, the Northern Septenar strophes of the Towneley play identify it as a play of the parent cycle. ${ }^{66}$

The York revision was probably made with two fundamental ideas in view: (1) the desire to bring the character of Pilate into closer conformity with scriptural accounts by making him kindlier in his attitude towards Jesus and anxious to avoid injustice $;^{67}$ and (2) to present the details in as realistic a manner as possible. To the first of these reasons, the following changes may be ascribed:

(1) The York Pilate immediately perceives the Jews' hatred of Jesus, whereas the Towneley Pilate joins with the high priests in their antagonism against him.

(2) In Towneley, the warning to be more temperate is directed against Pilate by his subordinates, but in York, it is Pilate who bids the high priests be more temperate.

(3) In keeping with the deceitfulness of Pilate and the high priests, in Towneley, Judas is thanked and praised because of his treachery, while in York he is cursed and maltreated.

The following changes may be explained by the second reason:

(1) Judas' reason for selling Jesus, although developed by similar details, is introduced at different points in the presentation. In the York play, Judas' recital of his grievances serves as a happy means of impressing upon the audience the idea of his grim aspect, to which in the scene that follows, the porter takes so violent and sudden an exception. In Towneley, the reason is not divulged until the terms of the bargain are being discussed.

(2) The refusal to grant Judas admittance to the council chamber has been motivated, in the York revision, by the introduction of a new character, the porter, who, believing he sees treachery on Judas' grim face, orders him away.

The six strophes in the characteristic metre of the Wakefield author, which form the introduction to the Towneley Conspiracio, are not, as Professor Cady believes, ${ }^{68}$ the remains of an early Towneley play upon which the Northern Septenar strophes of a York play have been engrafted, but are rather to be regarded as a later addition to the Northern Septenar strophes. ${ }^{69}$ Otherwise, it would be difficult to explain the existence of similarities between the introduction and the body of the play: ${ }^{70}$

"See above, ch. I, pp. 5-9.

6 In fact, this theory for the play has already been suggested. Professor Davidson's rhyme scheme tests (op. cil. 145) indicated that the Northern Septenar strophes of the Towneley play were written by the author responsible for the Northern Septenar plays in the York cycle.

se above, ch. III.

67 This difference in the conception of Pilate's character is seen in all the Passion plays of the two cycles. In Towneley, his attitude is as brutal and scheming as is that of the high priests. This must have been the view of the parent cycle, preserved now in the Towneley plays, but modified in the York revisions.

s Cady, op. cit. Mod. Phil. 10:590.

u See Mrs. Frank, op. cil. Mod. Phil. 15:181, n. 4.

10 The similarities occurring in the extant introductions of the two plays have already been presented. See above, ch. I, p. 5-6. 
(a) From Wakefield strophe in the introduction:

he prechys the pepyll here/ that fature fals ihesus,

That if he lyf a yere/ dystroy oure law must vs;

And yit I stand in fere/so wyde he wyrkys vertus,

No fawt can on hym bere/ no lyfand leyde tyll vs;

Bot sleyghtys

Agans hym shall be soght,

that all this wo has wroght. ( $37 \mathrm{ff}$.)

From Northern Septenar strophe in the body of the play:

Sir, oure folk ar so afrayd,

thrugh lesyns he losys oure lay;

Som remedy must be rayd,

So that he weynd not thus away.

Now certan, syrs, this was well sayd,

and I assent, right as ye say,

Som preuay poynt to be puruayd

To mar his myght if [that] we may.

ftor certan, syrs, ye say right weyll

ffor to wyrk witterly;

Bot yit som fawt must we feyll,

wherfor that he shuld dy. (\$6 ff.)

(b) From Wakefield strophe in the introduction:

If this be true in deyd,

his shech shall spryng and sprede,

And ouer com euer ylkone. ( $51 \mathrm{ft}$.)

From Northern Septenar strophe in the body of the play:

Towchyng that tratoure strang,

that makys this beleyf,

ffor if he may thus furth gang,

It will ouer greatly grefe. (62 ff.)

The Last Supper.-The chart analysis presented above, ${ }^{71}$ makes it apparent that, in the case of the Last Supper, York and Towneley selected in common many incidents from the Northern Passion. Although the Hegge plays also make use of the same source, ${ }^{72}$ a different set of incidents are selected and emphasized from those appearing in both York and Towneley. ${ }^{73}$ The many similarities existing in York and Towneley, then,

n See above, ch. I, pp. 9-13.

$n$ Foster, op. cit. EETS $147: 84 \mathrm{ff}$.

I (1) The interruption of the incidents of the Last Supper by the introduction of events treated in another play in York and Towneley, such as the conspiracy of the Jews, the anointing of Jesus' feet, Judas' anger, the bargain and the selling of Jesus, shows that Ludus Coventriae follows a different model from that of York and Towneley.

(2) The difference in the underlying conception of the Ludus Coventriae play is also borne out by the different development of certain incidents.

(a) It repeats Jesus' foretelling of his betrayal and Judas' departure for the high priests.

(b) It does not consider the shepherd and herd illustration, given a prominent position in both York and Towneley.

(c) Jesus' final speech follows a different model from that of either York or Towneley.

(d) The position of Jesus' foretelling of Peter's denial, at the close of the Ludus Coventriae play. differs from its introduction at an earlier point in both York and Towneley,

(3) Ludus Coventriae includes incidents not found in York and Towneley:

(a) The blessing of the bread and wine by Jesus, and his offering them to the disciples as a token of his body and blood.

(b) The entrance of the demon, gloating over the condemned soul of Judas, which he will soon claim as his own. 
may be explained by supposing their presence in the parent cycle, now extant in the couplets and perhaps the quatrains of the Towneley play which, according to the theory of a Northern Septenar revision in York, ${ }^{74}$ must have been revised in that metre for York after the separation.

That the extant Towneley play represents, indeed, an earlier version than the extant York play is indicated by the extended verbal agreement which exists between certain of the couplets and the narrative source: $:^{75}$

NORTHERN PASSION

Sir whare wilt pou halde thi feste we willene gane sythene maste \& leste Ihesu ansuerde sone on ane and callede to hym Petir \& Iohne

Gase he saide je schall fynd \& mete a man with watir in be strete

pe house pat he gose to with grythe ze sall hym folowe \& gaa hym with. the lorde of be house 5 e schall fynde a symple mane of sely kynde To hym 5 e sall speke and saye

I come sone in my waye.

I will festene in his haulle

Me and Myne discypills alle. (177-90)

Thesus bad bam all sit doune

And to his biding war pai bowne. $(204 a-b)$

Iudas saughe pay sittene alle agayne Ihesu he gane downe falle pat he moughte with hym ete his tresoune ne wolde ne noghte forgete

he stale owte of his lordis dysche be beste Morsclle of his fysche. (209. 14

With tresun sall I be bitrayd,

And ilkone by pam self serely Said pusgate: "lorde, es it oght I pat swilk treson has paruaid?" (244a, $257-59$ )

Or be cokke thrise sall crawe 3ow sall forsake me in a thrawe. (409. 10)

$\mathrm{Vp}$ he rase right fra be burde And toke a clath with milde chere And a bacyn with water clere. (330-32)

\section{TOWNELEY}

Sir, where will ye youre paske ete?

Say vs, let vs dight youre mete.

Go furth, Iohn and peter, to yond cyte; When ye com ther, ye shall then se

In the strete, as tyte, a man

beryng water in a can;

The house that he gose to grith,

Ye shall folow and go hym with;

The lord of that house ye shall fynde, A sympyll man of cely kynde;

To hym ye shall speke, and say

That I com here by the way;

Say I pray hym, if his will be,

A lytyll whyl to ese me,

That I and my dyscypyls all

myght rest a whyle in his hall. (314-29)

Sir, youre mett is redy bowne,

will ye wesh and syt downe?

yei, gyf vs water tyll oure hande,

take we the grace that god has send;

Commys furth, both oone and othere

If I be master I will be brothere. (346-51)

Tunc comedent, \& Iudas porrigit mantum in discum cum Ihesu. ${ }^{76}$

Iudas, what menys thou?

No thyng, lord, bot ett with you. $(352-53)$

for oone of you shall [me] betray.

(Pet.) lord, I shall neuer the betray; Dere master, is it oght I?

$(\mathrm{John})$ Master, is oght I he then?

(And.) Master, am oght I that shrew?

(Sim.) Master, then is oght I?

(Phil.) Is it oght I

(Thad.) Was it oght I : (355 ff.)

Peter, thou shall thryse apon a thraw

fforsake me, or the cok craw. (380-81)

Take vp this clothe and let vs go, ffor we haue othere thyngs at do. $(382-83)$

"See above, ch. II, $30 \mathrm{ff}$.

"Miss Foster, loc. cit., has already noted some of these verbal agreements.

7 A stage direction. 
And on his knese down gan he fall And said pat he wald wass his fete. (334-36)

I haue done 3 e ne wate whatt.

pou gettes no part with me in blis. pan said peter and oper ma:

"pat blis, lord, lat vs noght forga,

Wasche heuid and hend lord pray we pe." (341-45)

Maister and lord now je me call

And wele 3 e say for I am so.

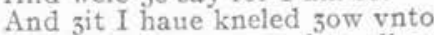

And wasschen 3 owre fete all on raw,

So pat 3 e sall ensample knaw. (358-62)
Sit all downe, and here and sees, ffor I shall wesh youre feet on knees. (384-85)

Why I do it thou wote not yit. Bot I the wesh, thou mon mys parte with me in heuens blys.

Nay, lord, or I that forgo,

wesh heede, handys, and feytt also. (392-95)

Ye call me master and lord by name; Ye say full wele, for so I am;

Sen I, both lord and master, to you wold knele

to wesh youre fete, so must ye wele. Ensaumpyll haue I gyffen you to. (404-9)

The Towneley couplets, it will be noted, follow the order of the Northern Passion account, save for the position of the foretelling of Peter's denial. The passage which has been cited as evidence pointing to a lost foot-washing scene ${ }^{77}$ is, in the light of the source, merely an introduction to the Eucharist. Such an arrangement of incidents is not, then, indicative of confusion on the part of the playwright ${ }^{78}$ and can not, therefore, be advanced as evidence pointing to the editorial work of a couplet writer at work on the Towneley cycle $^{79}$ after its separation from York.

A gap in the York manuscript and the corruption of the Towneley text, make it difficult to point out the changes made in the York revision. With the exception of the introductory scene where the disciples arrange for the house for the Last Supper, believed by Professor Cady to have been dropped from the York cycle when the separation into different plays occurred, ${ }^{80}$ and Jesus' final sermon to his disciples, the York play contains not only all of the incidents included in the Towneley play, but also three additional incidents derived from the Northern Passion. It must, therefore, have made a second and more extensive use of the source upon which the parent play was based. Accordingly, the incidents added to York at this time were:

(1) The quarrel among the disciples as to the leadership after Jesus' death,

(2) Jesus' commending the disciples to Peter's care.

(3) Jesus commanding the disciples to provide themselves with swords.

The Agony and Betrayal.-The similarities in structural outlines and phraseology between the York and Towneley plays of the Agony and

" Cady, op. cil. Mod. Phil. 10:591 ff.

7 Cady, (op, cit. JEGP 10:576 ff. and Mod. Phil. 10:593) remarking upon the corrupt condition of the Towneley play, calls attention to the repetition of the foretelling of Peter's denial and of a supposed foot-washing scene, the one presentation of the incidents being in couplets, the other in quatrains.

"See Mrs. Frank, op. cit. Mod. Phil. 15:182.

os Cady, op. cil. Mod. Phil. 10:593. 
Betrayal have already been presented above. ${ }^{81}$ We note here the same situation which existed in the Conspiracy and the Last Supper, namely, that although the Hegge play used the Northern Passion, it did not select or emphasize the incidents chosen in common by York and Towneley. This fact taken into consideration with the further development of certain incidents by means of similar details in both York and Towneley seems to point to a parent play, from which the extant York and Towneley versions were derived.

The corrupt form of the Wakefield stanza in strophes 97-102 of the scene connected with the capture of Jesus ${ }^{82}$ can not be regarded as a remnant of an earlier Towneley play upon which a simpler play in quatrains was engrafted. ${ }^{83}$ The three soldiers assure Pilate, in the usual boastful vein of the Miles Gloriosus, of their determination to seize Jesus at any cost: Malcus is ready to die for Mahound's sake if only he may be permitted to take Jesus; the second soldier boasts that, as sure as he eats bread, he will strike off Jesus' head; the third soldier glibly promises Pilate speedy vengeance, since three such knights as they could bind the devil himself. Pilate, in turn, salutes them as "curtes kasers of kamys kyn" and bids them bring Jesus to him "safe and sownde."

As will be seen, this material in the Wakefield strophes is merely a further elaboration of the incidents given in the simple quatrains, the suggestion for which is found in the Northern Passion: 84

pan pai come with ful grete rowte

And vmsett ihesus all obout

With swerdes \& maces \& glaues gude;

pai blew hornes als pai war wode

And in lanternes bare pai light,

And sum bare brandes brinand bright

pat pai might graithly se pe gat,

ffor it was in pe euenig late.

The dramatic presentation of these lines and their incorporation into both York and Towneley as a transition scene between Jesus' agony in the garden and his capture by the Jews point rather to a parent play from which both the extant versions have been derived. ${ }^{85}$ Evidence for this theory is seen in the further development of the scene in both cycles by means of similar details:

(1) The soldiers are armed with swords.

(2) Pilate, in Towneley, and the high priests, in York, show their eagerness in the search for Jesus by commanding the soldiers to seek everywhere for him:

si See above ch. I, pp. 13-18.

s Towneley Play XX, 11. 599-651.

"Cady, The Wakefield Group in Towneley JEGP 11:252 ff.

"Foster, op. cit. EETS 145:53.

as Probably the York play represents a later revision (see Gayley, Plays of Our Forefathers 154) of the parent play, now extant, perhaps in part, in Towneley. 
haue done, sir knyghtys, and kythe youre strengthe,

And wap you wightly in youre wede;

Seke ouer all, both brede and lengthe!

Spare ye not, spende and spede!

We haue soght hym les and more. (Towneley 1. $592 \mathrm{ff}$.)

Als 3 e are a lorde of grete renoune,

se spare hym not to spill.

pe devill hym spede!

Where $3 \dot{e}$ hym see, on hym take hede.

We schall hym seke both even and morne. (York 1. $215 \mathrm{ff}$.)

(3) Malcus brings a light to bear before the soldiers.

(4) The command is given to begin the search.

At this point, in the Towneley play, the Wakefield strophes occur, and comparison with the Northern Passion and the York play makes it clear that they are a later addition. ${ }^{86}$

Nor can there be any doubt that the York play represents a revision. ${ }^{87}$ The dissimilarities now existing between York and Towneley can therefore be adequately explained on the ground of later revisions:

(1) York elaborates many of the incidents provided for in the parent play and repeats Jesus' command to the disciples to watch and to pray not to fall into temptation.

(2) On the other hand, the Wakefield strophes in the midst of the quatrains indicate a further elaboration in Towneley of the incident showing the eagerness of the soldiers to hunt for Jesus.

(3) Certain additions in the York play point to a second and more extensive use of the Northern Passion, as seen in the incident where the soldiers fall to the ground at the sight of Jesus' divinity and Jesus' assurance that he could have a host of angels to testify to his power if he so wished.

(4) In accordance with its conception of Pilate, the Towneley play shows him as the instigator and director of the preparations made to seize Jesus; the revised York play, on the other hand, with its changed view of Pilate's character, ${ }^{88}$ assigns the role to the high priests.

\section{The Crucifixion and Burial}

The similarities existing between the York and Towneley plays dealing with the Crucifixion and Burial have already been presented. ${ }^{89}$ The two York plays, XXXV and XXXVI, seem to be expanded versions of the one Towneley play, XXIII, and many of the differences now existing may be accounted for by this expansion. In the development of details, the York plays are long drawn out, with much repetition, as in the case of the soldiers' mockery of Jesus, where they deride his claim to kingship and his claim of being able to tear down the temple and rebuild it in three days.

\footnotetext{
"s See Mrs. Frank, op. cit. Mod. Phil. 15:181, n. 4.

"7 See Hohlfeld, op. cit. Anglia 11:248; Gayley, op. cit. 154.

ss See above, ch. II. p. 44 ff.

see above, ch. I, pp. 24-28.
} 
In Towneley, the incident occurs once, 11. 486-97, but in York, it is given in both plays, P1. XXXV, 11. 273-83 and P1. XXXVI, 11. 79-91. In one instance, a long speech by Jesus is split into several parts in the York revision, different parts appearing at different places in both plays. ${ }^{90}$ Not only does the treatment of the subject-matter point to a later revision and further separation into two plays by York, but the metre also bears out the same assumption. The two York plays, the one, the Crucifixion, in the Northern Septenar and the other, the Mortificacio, in a later modification of it, are later stanzaic forms ${ }^{91}$ than the simpler and more common rime couee, in which the body of the Towneley play is composed, and which presumably represents the parent play, in part, at least.

The Towneley play also has undergone revision in certain strophes which closely resemble the work of the Wakefield author. ${ }^{92}$ Probably, the strophes in the medial rhymed quatrains of three accents to the halfline, and the strophes rhyming aabaabbcb and aabccbbdbd also represent revisions. These strophes are mainly concerned with the boasting of Pilate, the lamentations of Mary, and the suffering of Jesus, just such incidents as would readily adapt themselves to elaboration and revision.

\section{The Appearance of Jesus to Mary Magdalene}

Similarities in structural outlines and isolated phrases occur between the York and Towneley plays of Jesus' Appearance to Mary Magdalene:

(1) Mary, searching for Jesus' body, asks the gardener where he has put it. Compare T 11. 581, 563-68, 573-74 and Y I1. 70, 42-43, 38 for verbal similarities, with the retention of one rhyme word, away, and other phrases.

In fayth I haue hym soght.

. . . . I haue pe songht.

Say me, garihynere, it the pray,

If thou bare oght my lord away;

The stede thou bare his body tyll

Therfore, goode gardiner, sais bou me, I pray pe for the prophetis sake,

Tell me I the pray.

(2) Jesus reveals himself and Mary recognizes him.

(3) At Mary's desire to kiss his feet, Jesus commands her not to touch him. Compare T $11.592-96$ and Y $11.82-85$ for verbal similarities with the retention of one rhyme word, Trinite.

Nay, mary, neghe thou not me,

ffor to my fader, tell I the,

yit stevynd I noght;

Negh me noght, my loue, latte be!

Marie, . . .

To my fadir in Trinite

Forpe I stigh nozt yette.

Before theym all in irynyte.

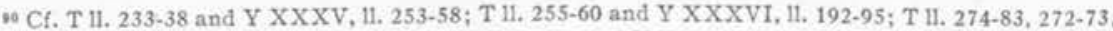
266 and $\mathrm{XXXXV}, 1.52, \mathrm{XXXVI}$, I1. 118-28; T 11. 290-4 and $\mathrm{Y} X X X V, 11.259-64, \mathrm{XXXV1}$, 11. 254-58.

$n$ The theory of the Northern Septenar revision was presented above, ch. II. Gayley, op. cil. 57 , considers the strophe form of the Mortificacio an indication that the play was revised.

n Bunzen, op. cit. 49, thinks the strophes in question are the work of the Wakefield author. 
(4) Jesus bids her tell the disciples of his resurrection.

The presence of "Burns" strophes in the Towneley play identifies it as perhaps a part of the parent cycle, ${ }^{93}$ of which the York play, with its greater elaboration of details, probably represents a revision. York elaborates the following points:

(1) Mary's opening lament at Jesus' tomb, where she feels she has 'lost her wits" and prays God to permit her to see Jesus or his messenger.

(2) Jesus, in the guise of a gardener, wishes to know what Mary would do with the body if she had it.

(3) When Jesus reveals himself to Mary, he shows his wounds in testimony of his identity,

(4) Mary's praises of Jesus are elaborated upon and closely resemble the general spirit and wording of numerous medieval lyrics." She lauds him as a comely conqueror whose love is sweeter than honey.

(5) Jesus' reply in the same fantastic strain may also belong to the same type of literature. Jesus gives a detailed description of his mighty armor, likening his leather hauberk to his head and his breast-plate to his out-spread body.

\section{The Peregrini}

Although the same incidents are contained in the play of the Peregrini in the four English cycles, it is noteworthy that York and Towneley agree in elaborating the essential incidents by the addition of similar details, often with the use of parallel phraseology.

(1) In the four plays, the disciples meet and mourn Jesus' death. The lamentations in York and Towneley are more elaborate than in the other two cycles. They also agree in giving a more detailed account of the cruelties suffered by Jesus and in calling to mind certain details connected with the crucifixion. Compare T 11. 15, 30 and $Y$ 11. 20-21; T 1. 57 and $Y$ 11. 106, 81 for verbal similarities.

Blo,thou bett hym bare.

And forto bele his body blo.

Vnto the ded yit thay hym dight.
Howe bei belle pat body was bote of all bales

With buffettis pei bete hym full barcly.

pus with dole was pat dere vnto dede dight.

To pe dying pei dight hym.

(2) Jesus, in the guise of a pilgrim, meets the disciples and inquires into their trouble. Compare T II. $98-99$ and Y 11. 67-69, 72 for verbal similarities, with the retention of one rhyme word, way (wayes in $\mathrm{Y}$ ), and other phrases.

Pylgrymes, whi make ye this mone,

And walk so rufully by the way?

(3) The disciples tell about the report of the women. Compare T 11.186 .88 and Y 11. 116-19 for verbal similarities, with the retention of one rhyme word, sight, and other phrases.

"See above, ch. III, $47 \mathrm{ff}$.

u See lyrics printed by Mr. Taylor, op. cit. Mod, Phil. 5:1-38.
What are pes meruailes pat $3 \mathrm{e}$ of mene, And pus mekill mournyng in mynde pat $\mathbf{5 e}$ make,

Walking bus wille be bes wayes? 
Bot saide a light

Com downe with angels, and vp hym broght

Tharein thare sight.
Howe all was lemand light wher he was laide

For certayne pei saugh it in sight.

A visioune of aungellis bright.

(4) The disciples assert that, although they distrusted the report, they found it to be true. Compare T 11. 195-96 and Y 11. 123-24 for verbal similarities.

yee, som of $\mathrm{vs}$, sir, haue beyn thare,

And faunde it as the women saide.
Some of oure folke hyed forthe and faste pei it fande,

pat all was soth pat pei saide. .

Immediately preceding the disciples' account of the women's report, the York and Towneley peregrini tell the stranger that they are awaiting Jesus' resurrection the third day as he had foretold. The position of this detail appears significant, because in both Chester and Ludus Coventriae, it occurs at other points in the presentation.

(5) Jesus reproaches the disciples for their disbelief ${ }^{95}$ and quotes prophecies.

(6) The peregrini invite Jesus to remain for the night. Compare T $11.240-41$ and Y 11. 143-44 for verbal similarities.

Now sir, we pray you, as oure freynde, All nyght to abyde for charite.

All nyght we thynke for to byde here, Bide with vs, sir pilgrime, zoe pray $30 u$.

Chester does not include the desire, expressed by the disciples in the other plays, to hear more of the stranger's talking. His conversation is characterized as "kyndely" in York and Towneley, but not in the other cycles. With Jesus' reluctance to remain, but final acceptance of the invitation, the similarity in the fundamental outlines of the four plays is resumed.

(7) The similarity is continued in the vanishing of Jesus immediately after he has blessed the bread. Compare T 11. 391-92 and Y 11. 160-62 for verbal similarities not found in the other cycles.

. where is this man becom,

Right here that sat betwix vs two.
Saie! wher is pis man?

A way is he went,

Right now satte he beside vs!

(8) The realization on the part of the disciples that the stranger was Jesus occurs in all four plays, as well as their rejoicing and departure to tell the other disciples. Compare T 11. 363-65 and Y $11.188-89$ for verbal similarities. ${ }^{96}$

Such an extensive similarity can not be adequately explained, as Professor Cady suggests, ${ }^{97}$ by the theory of a common liturgical source. The "Burns" stanzas, forming the body of the play, identify it as a part of the parent cycle, ${ }^{98}$ and the York play may be regarded as a revision of it. The conciseness with which the York incidents are presented appears to point to an intentional condensation of the play. A passage in the York text clearly indicates a limitation in time:

or See T 1. 202, Y I. 130, Ch p. 104 and Hegge plays p. 367 for verbal similarities.

n Compare Ch p. 106 and Hegge plays p. 371 for verbal similarities not so close as those existing between York and Towneley,

97 Cady, Op. cit. PMLA 24:464.

is See above, ch. III, 47 ff. 
Here may we notte melle of more at pis tyde,

For prossesse of plaies pat precis in plight. ${ }^{93}$

On the other hand, isolated strophes in the characteristic metre of the Wakefield author ${ }^{100}$ and the stanzas rhyming ababcbc, which occur either in connection with the Wakefield strophes or separately, ${ }^{101}$ represent probable additions in the Towneley cycle. These strophes, it should be noted, consist merely in repetitions of material already presented or show an expansion in phraseology.

\section{THIRD GROUP OF Plays}

In the third group, we have the plays which show a similarity in structural outlines and verbal reminiscences in isolated passages. Such resemblances, in conjunction with the extensive agreements in the plays of the first two groups, we believe indicative of a former identity. Because of the absence of common rhymes, we must suppose the revisions of the plays in this group more thorough than those in the first two groups. In most cases, it is probable that the plays underwent independent revisions in both cycles.

\section{Noah and the Flood}

Similarities in structural outlines and verbal reminiscences in isolated passages occur between the York and Towneley plays dealing with Noah and the Flood:

(1) God finds that that part of his creation, man, in whom he has taken the greatest pride, lies deep in sin. Compare T $11.28-31,111$ and Y P1. VIII, $11.6-16$ for verbal similarities.

, to his liknes maide man, Adam \& eue that woman.

To multiplie without discord,

In erth i se bot syn reynand to and fro.
And to my liknes made I man,

A woman also with hym wrought $\mathrm{I}$,

I badde pame waxe and multiplye,

To fulfille this worlde, withoutyn striffe

And synne is nowe reynand so ryffe.

(2) God repents ever having made man and decides to destroy him by means of a flood, saving only Noah, his family, and two of each of the animals. Compare T 11. 91-101 and Y P1. VIII, 11, 15-16, 27-28 for verbal similarities.

I repente full sore that ener maide $I$ pat me repentys and rewys forpi man.

pat euer I made outhir man or wiffe.

Therfor shall i fordo all this midellerd

With floodis that shall flo.

A flowyd above pame shall be broght,

To stroye medilerthe, . . .

"York Play XL, II. 191-92.

100 Towneley Play XXVII, str. 3 and 30.

161 Towneley Play XXVII, str. 1 and 2 in connection with Wakefield str. 3 ; str. 29 and 31 in connection with Wakefield str. 30 . Str. 33,39 , and 48 occur separately. 
(3) God appears to Noah and gives him the instructions for building the ship and filling it, telling him that it will begin to rain in seven days. Compare T 11, 147-48 and Y Pl. VIII, $11.138-39$ for verbal similarities.

It shall begyn full sone to rayn vncessantle,

After dayes setien be done and induyr dayes fourty.

(4) Noah rejoices that he should be so favored, but complains of his inability to carry out the plan because of his old age.

(5) Noah works on the ship alone for a hundred years.

(6) A comic altercation between Noah and his wife ensues. The wife, urged by her husband to enter the ark, stubbornly refuses, offering excuses. The argument increases in vehemence until finally blows are exchanged. In the end, the wife is overcome and forced to enter the ship.

(7) The flood rises.

(8) The flood wanes.

(a) Twice, we are told that the waning has set in. Compare T 11. 450, 458 and Y P1. IX, 11. 188, 204 for verbal similarities.

It is wanyd a grete dele.

Yei, now wanys the see.

For be the wanyng may we witte

It is wanand, pis wate I wele.

(b) The cataracts are knit together and the sun appears in the horizon. Compare T 1. 451 and Y P1. 1. 190 for verbal similarities.

. . . . . and cateractes knyt. The catteraks I trowe be knytte.

(c) Three hundred and fifty days have passed in Towneley since the beginning of the flood and nine months in York, as against the traditional forty days.

(d) Noah, sounding the sea, finds that it is fifteen cubits deep. Compare T 11 . 433-34 and Y Pl. IX, 11. 195-96 for verbal similarities.

The depnes of the see.

I sall assaye pe see,

How depe pat it is here.

(e) At the sight of the hills of Armenia, there is rejoicing; pe hillis of hermonye, see T 1. 466 and Y Pl. IX, 1. 264.

(f) The raven is sent out but fails to return.

(g) The dove is sent out and returns with the olive branch, the token of their salvation; we shall be sauyd all, T 1. 517, and we mone be saued, Y 1. 260.

(9) As the family leave the ship, they remark upon the desolation of the land and the drowning of the people.

These similarities appear to indicate a parent version of which the extant York and Towneley plays represent independent revisions. ${ }^{102}$ The two York plays are thought to have been written under the same influence as that which dominated the Northern Septenar productions, ${ }^{103}$ and may, therefore, be regarded as revisions of an earlier play. ${ }^{104}$ The Towneley

102 Certain similarities with Chester may be explained by assuming that Chester came in contact with the parent play or some earlier version of it than those now extant.

$10 s$ Davidson, op. cil. $144 \mathrm{ff}$.

104 See above, ch. II, p. 30 ff. Although Professor Hohlfeld (Anglia 11:288) admits that the York and Towneley plays stand very close to each other in many respects, he thinks the differences so numerous and so important as to make improbable a direct relationship between the two. Professor Gayley (Plays of Our Forfothers 168), on the other hand, believes the influence of York upon Towneley not unlikely. 
play, composed in the characteristic metre of the Wakefield author, also represents a revision. ${ }^{105}$ Thus, the dissimilarities are adequately explained:

(1) The York play handles certain incidents not treated in Towneley; namely, the wife's refusal to enter the ark without her gossips and the appearance of the rainbow.

(2) As an excuse for her reluctance to enter the ark, the Towneley wife expresses a desire to continue her spinning, the York wife to go to town.

(3) The satiric remarks directed in general against husbands, wives, and marriage by the Towneley Noah and his wife are characteristic of the Wakefield author. The greater violence of the Towneley scene may also be ascribed to his pen, as well as the additional scene of altercation, when the wife learns of the command to build the ship. The additional comments at the close of the play concerning the desolation and death caused by the flood are probably also by the same author.

\section{The Annunciation}

In structural outline and phraseology the English plays on the Annunciation agree closely. ${ }^{106}$ In three incidents, however, York and Towneley make use of certain phrases not found in the other cycles:

(1) Mary can not understand the fulfillment of the angel's command. Compare T 11. 111-14 and Y 11. 170-74.
$A$ child to bere thou me hetys,
How suld it be?
Howe sulde it be, I the praye,
I cam neuer by man's syde,
Bot has avowed my madynhede.
That I sulde consayve a childe
I knawe no man pat shulde haue fyled
My maydenhode, the sothe to saye.

(2) Mary is told that Elizabeth also has conceived a son. Compare T 11. 134-39 and $\mathrm{Y}$ 11. 181-84.

Elesabeth, thi Cosyn, that is cald geld She has conceyffed a son in elde,

And this is . . . . . .

The sext moneth : . . . :
Loo, Elyzabeth, pi cosyne, ne myght

In elde consayue $a$ childe for alde,

pis is pe sexle moneth full ryght.

(3) Mary, praising God, resigns herself to his will. Compare T $11.143-47$ and Y $11.187-92$.

I lofe my lord all weldand,

I am his madyn at his hand,

I trow bodword that thou me bryng,

Be done to me in all thyng.
I love my lorde with herte dere,

Goddis handmayden, 10 ! me here,

To his will all redy grayd,

Be done to me of all manere,

Thurgh thy worde. . . . .

Since the Towneley Annunciation is contained in the same play as Joseph's Trouble, in all probability a part of the parent cycle, ${ }^{107}$ one may surmise that it also represents the parent play which has been revised by York in a different metre but without any elaboration of subject-matter.

100 See Mrs. Frank, op. cil. Mod. Phil. 15:181, n. 4.

100 See Hohlfeld, op, cit. Anglia 11:290, Davidson, op. cit. 158-63, Cady, op. cit. PMLA $24: 435$ ff. and Hemingway, op. cil. intro, xvii for the different theories advanced to explain the relationship.

107 See above, p. $56 \mathrm{ff}$. 


\section{The Visit to Elizabeth}

As in the case of the Annunciation, the Visit to Elizabeth in the English cycles is composed of common incidents which closely follow the scriptural narrative. York and Towneley, however, agree in certain details and phraseology not found in the other cycles:

(1) The welcome by Elizabeth. Compare T 11. 4-6 and Y 11. 201-4 for verbal similarities.

Welcom, mary, blyssed blome,

Ioyfull am $I$ of thi com

To me, from nazareth.

(2) The inquiry concerning the relatives. for verbal similarities.

ffull lang shall I the better be,

That I may speke my fyll with the, My dere kyns Woman:

To wytt how thi freyndys fare.

(3) Elizabeth's commendation of Mary for placing her trust in God. Compare T 11. 43-48 and Y 11. 225-32 for verbal similarities.

\section{And als, mary, blyssed be thou, \\ That stedfastly wold trow,}

That vnto the were sayd or send.

$$
\begin{aligned}
& \text { Welcomel mylde Marie, } \\
& \text { Joifull woman am } I_{\text {, }} \text {. } \\
& \text { pat I nowe see pe here. }
\end{aligned}
$$

Compare T 11. 13-16 and Y 11. 197-99

Elyzabeth, myn awne cosyne,

Me thoght I coveyte alway mast

To speke with pe of all my kynne.

(4) Mary's desire to pray. Compare T 11. 49-51 and Y 11. 237-40 for verbal similarities, with the retention of one rhyme word, hele, and other phrases.

My saull lufys my lord abuf,

And my gost gladys with luf,

In god, that is my hele.

Blissed be pou grathely grayed pou trowed and helde be payed

All pat to be is saide.

If, as we suggested above, the York play of the Annunciation represents a revision of the Towneley play, then the York Visit, composed in the same metre and included in the same play as the Annunciation, likewise is a revision. If this be the case, the York revision appears to have been influenced, as in the Northern Septenar plays, ${ }^{108}$ by a desire to conform more closely to scriptural accounts. It not only follows the correct order of events, Annunciation, Salutation, Joseph's Trouble, rather than the incorrect order given in Towneley, but it also omits much of the extraneous matter concerning the relatives which the Towneley play introduces.

\section{The Examination before Caiaphas}

Among the English cycles, only York and Towneley separate the incidents connected with the Examination of Caiaphas from the incidents connected with the various trial scenes and make of them a complete play. Moreover, certain similarities in structural outlines and phraseology occur: 
(1) Jesus, mocked and abused by the soldiers, is led to Caiaphas.

(2) The soldiers complain bitterly about the difficulty and weariness of the journey.

(3) Accusations are brought against Jesus: that he claims to be able to destroy the temple and rebuild it in three days; that he cures the sick; that he breaks the Sabbath; that he calls himself God's Son (Men call hym a prophete and goddis son of heucn, T 1. 91 and Callis hym selffe God sone of hevene, Y 1. 50) and cares nothing for Caesar.

(4) Caiaphas, himself, offers to examine Jesus. Compare T II, 128, 235 and Y 1. 275 for verbal reminiscence.

ffor certys, I my self shall/ make examynyng.

And therfore examynyng ffyrste will 1 make.

(5) Jesus refuses to answer.

(6) The Jews, angry because of Jesus' silence, wish to beat him.

(7) Upon being asked whether or not he is the son of God, Jesus answers. Compare T 11. 249-54 and Y 11. 292-97 for verbal similarities.

(8) The Jews then consider that no more witnesses are needed. Compare T 11. 259-60 and Y $11.302-5$ for verbal similarities.

Thou art worthy to del we nede no wyines,

hys self says expres.
For my selfe schall serche hym and here what he sais.

(9) Since Caiaphas does not possess "temporal" power, they decide to send Jesus to Pilate for judgment. Compare T 1. 291 (Sich men of astate shuld no men deme) and Y 1.339 (3e awe to deme noman).

(10) They order Jesus beaten.

(11) The scene of the buffeting.

(12) Jesus is led away to Pilate.

Of these incidents, those numbered (2), (6), and (9) do not occur in the source, the Northorn Passion, ${ }^{109}$ and may, therefore be regarded as evidence pointing to a parent version, of which the extant York and Towneley plays are revisions. In both cycles, the play is composed in a late metre: in York, it occurs in a corrupt modification of the Northern Septenar, ${ }^{110}$ and in Towneley in the characteristic strophe of the Wakefield author. ${ }^{111}$ In its revision, York apparently added two new scenes: the preliminary court scene and perhaps Peter's denial. The former scene was probably a special feature since it contains material derived from the Gospel of Nicodemus. ${ }^{112}$

\footnotetext{
100 See above, ch. I, pp. 18-20.

in Hohlfeld, op. cil. Anglia 11:248, Gayley, Plays of Our Forefathers 154, and Davidson, op. cil. 137 regard it as a late play.

us See below, p. 101.

11 For incorporation of material from Gospel of Nicodemus, compare Y 11. 33-39 and G of N $11.39-44$, Y II. 40-45 and G of N Add. 11. 29-38, Y II. 50-54 and G of N 11. 22-28, Y 1. 57 and $G$ of $N 11.47-48$.
} 


\section{The Ascension}

Similarities in certain details and in isolated passages occur between the York and Towneley plays of the Ascension:

(1) The disciples await together Jesus' coming and the approaching events.

(2) Jesus appears to the disciples, reproaches them for being hard of heart and unbelieving, and exhorts them to preach the gospel. "In hardness youre harlys ar fast" (T 1. 200), "And wondir harde of hartis ar $3 \mathrm{e}$ " (Y 1. 84).

(3) Jesus promises to return at Doomsday in order to judge man. In the meantime, he promises to send the Holy Ghost.

(4) The clouds open to receive Jesus and he ascends.

(5) Mary is both joyful and sorrowful at Jesus' departure. Compare T 11. 298301, 348-55 and Y 11. 179-82 for verbal similarities.

A selcouth sight yonder now is,

A selcouth sight is pis to see,

A clowde has borne my chylde to blys.

Mi sone pus to be ravisshed right

In a clowde wendande vppe fro me.

(6) Mary fears the Jews and John attempts to comfort her.

(7) The angels proclaim Jesus' ascension. Compare T 11. 254-68 and Y 11. 21924 for verbal similarities, with the retention of two rhyme words, Galile and se, and other phrases.

\author{
ye men of galylee, \\ wherfore meruell ye? \\ hevyn behold and se \\ how ihesus $v p$ can weynde \\ Right so shall he, securly, \\ Com downe agane truly, \\ with his woundys blody.
}

3e men of pe lande of Galile,

What wondir $3 \mathrm{e}$ to heuene lokand?

pis Jesus whome ze fro youe see

Vppe-tane, 3e schall well vndirstande,

Right so agayne come doune schall he,

When he so comes with woundes bledand.

(8) The disciples lead Mary away.

(9) The disciples leave for Jerusalem.

Undoubtedly, the Wakefield variants, the double quatrains, and the strophes rhyming ababbcbccded represent later additions, because the subject-matter with which they deal is a repetition or an elaboration of incidents contained in the simpler metres, the rime couée and the single quatrain. The single quatrains may also be a revision for the same reasons.

(1) Perhaps in imitation of the three appearances of Jesus in the Incredulity of Thomas, the Towneley play of the Ascension also makes him appear three times."11 The first appearance occurs in strophes rhyming ababbebceded and abab, ${ }^{114}$ the second appearance in ababbebccded, ababcddde, and aabeccb, ${ }^{115}$ and the third in single quatrains. ${ }^{116}$

(2) Mary repeats her comments upon Jesus' ascension, both times in single quatrains, which may be an indication of two quatrain writers, or the bungling work of one.

11 Hohlfeld, op. cit. Anglia 11:303 suggests that this is in imitation of the three appearances of Jesus in the Garden of Gethsemane.

ut Lines 25-52.

110 Lines 101-57.

116 Lines $194 \mathrm{ff}$. 
(3) Jesus' promise to come again at Doomsday occurs twice, once in the rime couće and again in single quatrains.

(4) The disciples' marvelling at Jesus' ascension seems to be a repetition in Wakefield variants of material given in single quatrains.

(5) John's attempt to comfort Mary occurs twice, both times in single quatrains, as in (2).

Certain of the incidents, common to York and Towneley, are further elaborated in York:

(1) Jesus' appearance is marked by the presence of additional details.

(2) In his reproach of the disciples, Jesus contrasts their distrust with Mary's loyalty.

(3) The disciples' marvelling at Jesus' ascension is much elaborated.

(4) The disciples promise to care for Mary as they lead her away.

(5) Mary proclaims Jesus as her son.

Thus, both the York and Towneley plays appear to be revisions of an earlier play. Perhaps, the parent play is extant, in part, in the rime couée stanzas of the Towneley play.

\section{Fourth Group of Plays}

In the fourth group, we have the plays which show certain similarities in structural outlines, but without extensive or significant agreements in phraseology. In the case of these plays, we can not be sure that the resemblance is indicative of an original identity. But on the other hand, it is possible that independent revisions destroyed traces of verbal agreement.

\section{Cain and Abel}

The gap in the York manuscript in the midst of the play on Cain and $A b c l$, covering such important incidents as the tithing and the murder of Abel, makes a complete comparison with the Towneley play impossible. In spite of this difficulty, however, York and Towneley show certain similarities in incidents and phraseology, not found in the other English plays. ${ }^{117}$ Both cycles include:

(1) A comic episode between Cain and his Garcio.

(2) Cain's obstinacy before acceding to Abel's entreaties to make the sacrifice.

Similarities in phraseology are found in the following lines:

(1) T 1. 174 and Y 1. 3.

God that shope both erth and heuen.

He shoppe pe sonne, both see \& sande.

(2) T 1.345 and Y 1.84.

What askis thou me? I trow at hell. What askes thowe me that taill to tell?

11 Because it treats incidents not found in York or Towneley, the Chester play differs considerably: (a) Adam's vision while Bve was being created; (b) Cain tells his parents of the murder; (c) the lamentations of Adam and Eve over the sorrows and misfortunes of life. 
(3) T 11. 351-53 and Y 11. 100-1.118

The voyce of thi brotheris blode from erth to heuen venyance cryse.

(4) T 1. 355 and Y 11.90 and 107. here I gif the my malison.

(5) T 11. 361-65 and Y 11. 121-26.

I shall hyde me fro thi face.

(6) T 1. 370 and Y 1. 128. ${ }^{110}$

Nay, caym, it bese not so. be voice of his bloode cryeth vengeaunce

Fro erthe to beuen.

God hais sent the his malyson. God has geffyn pe his malisonne.

Fro be shalle $I$ be hidde in hye.

Nay, Cayme nou 3 t soo, haue pou no drede.

The divergences in the two plays may be explained by later revisions in both cycles. The complicated strophe form of the York play (ababbcdbccd) may be evidence of a later revision of that play; at any rate, the Brewbarret episode was not entered in the Register until $1558{ }^{120}$ The variety of metrical forms in the Towneley play is itself an indication of revision.

The determination of the probable earlier and later stages in the development of the Towneley play and the relation of the play to the parent cycle present an interesting study. The greater part, in fact the body of the play, is written in couplets; a number of twelve- or thirteenline strophes, rhyming aaabcccbbdbd or aabccccbbdbd, appear at the beginning, and two strophes in the favorite metre of the Wakefield author at the close, while interspersed among the couplets occur variations of the simple rime conée, or what may be corruptions of the pedes of the twelveor thirteen-line strophe. ${ }^{121}$ Because of its extraordinary boldness and characteristic humor, as well as the presence of two Wakefield strophes, the play has generally been considered a later revision by the Wakefield author. ${ }^{122}$ Professor Cady, ${ }^{123}$ however, believes that the original play was composed in the twelve-line strophe form, and that the couplets represent a later revision. Professor Gayley, ${ }^{124}$ on the other hand, argues that the couplets represent the older play, asserting that the final reviser, "our Wakefield master has not only added the last two stanzas in his favorite form, but has probably lent spice to the first seven." He thinks that the

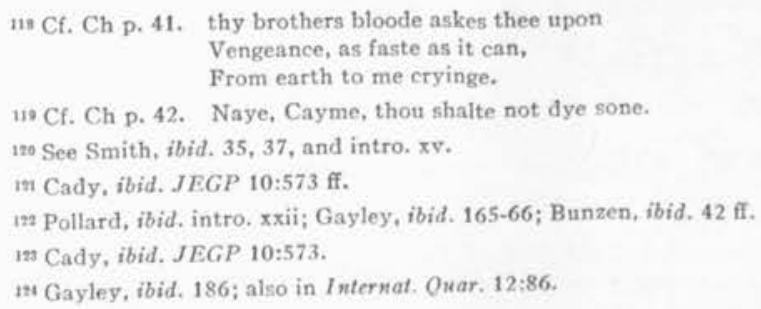


playwright left "the other stanzas much as they were," but "heightened the characterization of Cain and his boy, enriched their speech with proverbs, and made of Abel something other than the milksop presented in the earlier cycles."

It is, then, evident that the Towneley play is the work of at least two different writers, whose general method, style, and metrical form differ considerably. Humorous passages occur only in the twelve- or thirteenline strophes, the rime couee, and the irregular couplets, whereas the serious action of the play is developed in the couplets which are, for the most part, regular in metre and rhyme.

With the exception of two episodes, the failure of Cain's sacrifice to burn and God's curse upon Cain, the incidents occurring in the regular couplets form the framework of the play.

(1) Lines 68-77. Abel exhorts Cain to come with him and make burnt offerings of a tenth of his cattle and corn.

(2) Lines 91-96. Cain refuses to leave his plough and "work for God" who has given him only sorrow and woe.

(3) Lines 167-223. Abel finally prevails upon Cain to make the sacrifice. Abel tithes his shares first, lights them and humbly prays God to accept them. Then Cain begins his tithing, but offers his poorest corn and miscounts them. Abel remonstrates, but to no avail.

(4) Lines 311-27. Cain kills Abel with a cheek-bone.

On the other hand, additions to the fundamental incidents or elaborations of them occur in the twelve- or thirteen-line strophes, the rime conee, and the irregular couplets.

(1) Lines 1-36. Cain, introduced by a ranting speech of the Garcio, enters with his plough, and rails at his horse as "the worse mare" he ever had.

(2) Lines 37-56. A scene of wrangling between Cain and the Garcio.

(3) Lines 57-67. Abel, entering, greets Cain, but is ill-received.

(4) Lines 78-90; 97-166. Repetition and elaboration occur in connection with Cain's unwillingness to make the sacrifice and Abel's exhortations to him.

(5) Lines 224-310. The false tithing on the part of Cain, and Abel's remonstrance are elaborated upon. In connection with this scene, God reproves Cain who, in turn, is impudent.

(6) Lines 355-77. God, appearing to Cain, utters the curse, and Cain, lamenting, wishes to be buried in "Gudeboure." "izs

(7) Lines 378-473. Wishing to bury the body, Cain calls the Garcio, but is forced to give him a proclamation of pardon in order to insure his silence concerning the murder. Then Cain curses him, puts him to work with the plough, and bidding the spectators farewell, says he must betake himself to hell.

We may, then, conclude that the original play, perhaps the one present in the parent cycle, was composed in couplets, which was later revised by a writer who not only stressed the comic possibilities of the old scenes, but invented additional episodes, especially in connection with the Garcio.

12 Refers to Gudeboure Close in Wakefield. See Peacock, op. sit. Anglia 24:509 ff. Chambers, op. cit, 2:415. 
Still another criterion might be applied in the attempt to distinguish the remains of the earlier play from the later revision; namely, the two different spellings of the name Cain,- "Cam" and "Cayme,"-which are found in the text of the play. In general, the spelling "Cam" is used in the parts which, upon stylistic grounds, appear to be of earlier origin, whereas the spelling "Cayme" appears in the parts which seem to indicate a later revision..$^{126}$

\section{Abraham and Isaac}

The York and Towneley plays of Abraham and Isaac show certain points of similarity, which are not found in the other English plays:

(1) In his soliloquy at the beginning of the play, Abraham speaks of his age as being a hundred years. Compare T $11.9-10$ and 38 with Y 11.1 and 6 for verbal similarities.

Mercy, lord omnipotent!

long syn he this world has wroght.

Grett god, pat alle pis warld has wrought,

An hundreth yeris, certis, haue I seyne. $\quad$ A hundereth wynter to fulfille.

(2) God decides to test Abraham's faith.

(3) Abraham accepts God's command cheerfully. Compare T 11. 76, 81 and Y $11.75,103$ for verbal similarities, not found in the other plays.

ffor certis thi bidyng shal be done.

God wille pis dede be done.

This commaundement must I nedis ful. fill.

Goddis commaundement to fulfille.

(4) The York and Towneley plays include the two servants who lead the ass laden with wood for the sacrifice. Save for Dublin, none of the other plays mention servants.

(5) Only York and Towneley mention the length of time required for the journey, three days, and the name of the destination, Mt. Vision.

(6) The reference at the close of the York play to Rebecca may be evidence of the existence of a complete Abraham-family group in the parent cycle, as in the extant Towneley cycle. This reference appears to be significant, because none of the other plays look forward to a possible continuation of the group.

(7) The following similarity in phraseology is especially significant, with the retention of the two rhyme words, bowne and towne. Compare T $11.129-32$ and Y 11 . 113-17.

luke thou be bowne;

ffor certan, son, thi self and I,

we two must now weynd furth of towne,

In far country to sacrifie.

Att youre biddyng we wille be bowne, What way in worlde bat $3 \mathrm{e}$ wille wende.

Why, sall we trusse ought forthe a towne

In any vncouthe lande to lende?

The revision of the York play in the Northern Septenar ${ }^{127}$ is sufficient to explain the slightness of the resemblance between the two plays. Prob-

\footnotetext{
120 Suggested by Professor Manly.

127 See above, ch. II, p. 44 ff.
} 
ably the Northern Septenar playwright considered the pitiful pleadings of the Isaac, usually portrayed in the mysteries, ${ }^{128}$ undignified, if not sacrilegious. Isaac is, therefore, portrayed as a prototype of Christ, and consequently all reference to natural fears or misgivings, which might be construed as unbecoming, are consistently excluded. Nor is Abraham portrayed as a father torn between two great emotions, the feeling of parental love and the feeling of religious duty. The mother motif, given a prominent position in the other plays, is omitted, perhaps for the same reason.

The Towneley play may be an adaptation of an earlier York play, later discarded, as suggested by Professor Gayley. ${ }^{129}$ It may even be the earlier York play itself, but the presence of four couplets in the midst of the double quatrains seem rather to point to a still earlier play. Since the two plays immediately following it, Isaac and Jacob, supposed to be the earliest section of the cycle, ${ }^{130}$ are composed in couplets, it is possible to suggest that the parent cycle may have contained a complete Abrahamfamily group in couplets. ${ }^{131}$

Mr. Hugenin, ${ }^{132}$ following Professor Davidson's theory ${ }^{133}$ that a couplet editor worked over the Towneley cycle, concludes that the couplets in the Abraham play are a later interpolation from the Viel Testament, ${ }^{134}$ suggested by the mention of Adam in two of the double quatrain passages. ${ }^{135}$ Because of the references in double quatrains, however, it seems likely that the couplets represent, not a later interpolation, but the remains of an earlier play, and that the original couplet version contained three references to Adam, two of which underwent revision in quatrains, while the third remained intact in its original couplet form; or it may be, that the quatrain passages in question represent an elaboration of the couplets.

\section{The Scourging or Condemnation}

The twenty-second Towneley play, the Scourging, corresponds to two plays in the York cycle, the Condemnation and On the Way to Calvary. The practical identity of the incidents connected with On the Way to Calvary indicates the existence of a parent play which in its account of the Condemnation underwent revision in both cycles. The Towneley version of

"s Ct. Viel Testament, Chester, Towneley, Brome, and Dublin plays.

"Gayley, op. cil. 134, n. 1. See also Pollard, op. cit. xxvi.

130 Ten Brink, op. cif. $2: 244 ; 3: 274$.

$\mathrm{m}$ Because of the presence of the same type of couplets in the Foll of the Angels and Cain and Abel, it is even possible that originally the whole Old Testament group was composed in couplets.

in Hugenin, An Interpolation in the Towneley Abraham Play, Mod. Lang. Notes 14:256.

19 Davidson, op. cil. 130 and Cady, op. cil. JEGP 10:579 believe these couplets are editorial.

un Viel Testament, od. Rothschild.

1s The passages in question are Abrabam's monologue, where two stanzas are devoted to him, and line 61, where Adam's name is again mentioned. 
the Condemnation, composed in the characteristic metre of the Wakefield writer, and the York play, in a twelve-line alliterative stanza rhyming ababbcbcdccd, are clearly the result of late revisions ${ }^{136}$ which were so thorough-going, that although it is possible to trace a similarity in underlying structure, none remains in phraseology. ${ }^{137}$ This situation is explained, in large part, by the fact that the York play in its revision introduced certain incidents from the Gospel of Nicodemus, as the bowing of the standards, Pilate's forced obeisance to Jesus, and the suggestion that the high priests judge Jesus.

The York play, stripped of these incidents, assumes an outline which corresponds more nearly, not only to the extant Towneley play, but also to the earlier form of the York play as described by Burton in the 1415 list. ${ }^{138}$

The Towneley Pilate's pretence of befriending Jesus and the York Pilate's perception of the "hideousness" of the accusations are not inconsistent with the theory of an original identity of the two plays, for they are but manifestations of the difference in the characterization of Pilate already noted in the case of other plays. ${ }^{139}$

\section{Fifth Group of Plays}

It is impossible to make a complete comparison of the Purification, because of the fragmentary condition of the Towneley manuscript at this point. In the portion remaining, Professor Cady ${ }^{140}$ traces a similarity in underlying structure. Because of the addition of Anna and the clerks, he suggests that the York play is later. This conclusion is borne out by its confused metre and by its late entry in the register, in 1558. ${ }^{141}$ The Towneley play, composed in the rime couée, represents apparently an early stage in the Towneley cycle. ${ }^{142}$ The few points of similarity in structural outlines may be due to derivation from a common source, or it may be that this play was not present in the parent cycle.

\section{Sixth Group of Plays .}

It now remains to discuss the plays which are contained in only one of the cycles. Of the six Towneley plays not now included in York, two, the Hanging of Judas and the Talents, are subjects of older York plays ${ }^{143}$

19 See Gayley, op, cit. 154 and 161; Pollard, op. cit, intro, xxii; Bunzen, op. cit. 14 ff.; and below, p. 101.

is? See above, chart, ch. I. p. 20-22.

128 See Smith, op, cit. intro. xxv; and above, ch. II, p. 32.

120 See above, ch. II, p. 44 ff. and p. 78.

140 Cady, op. cit. PMLA 24:456.

14 See Smith, $O D$. cil. intro. $x \mathrm{v}$.

162 Pollard, op. cit. intro, xxiii f.; Gayley, op. cil. 161.

tas See 1415 Burton list, Smith, op. cil. intro. xix ff.; undated Burton list, Davies op. cil. app. 233; 1422 record. Mem. Bk., Sur. Soc. 120:155; Riley, Hist. MS. Report 1:109. 
and may, therefore represent the parent form. Two of the plays, Isaac and Jacob, are composed in couplets and the other two, the Prophetae and Octavian in the rime couee, metres which we believe were used to some extent by the parent cycle. ${ }^{144}$ The omission of these plays from the extant York cycle may have been due to the crafts which repeatedly discarded plays because they grew tired of them or were unable to support them. ${ }^{145}$

The omission of plays in the Towneley cycle may be explained, in part, by gaps in the manuscript. The gap of twelve pages near the beginning accounts for the loss of most of the Temptation of Adam and Eve and Their Fall, as well as the Expulsion. ${ }^{146}$ The gap of twelve pages near the end of the manuscript probably explains the loss of the play on the Descent of the Holy Ghost and perhaps also one or two Mary plays.

Again, it is possible that certain plays once forming a part of the Towneley cycle were not copied in the manuscript with the others. Since the two extant trial plays, the Examination before Caiaphas and the Final Condemnation by Pilate, ${ }^{147}$ occur in the characteristic metre of the Wakefield writer, Professor Cady ${ }^{148}$ suggests that the intermediate trial scenes, the First Trial before Pilate and the Trial before Herod, ${ }^{140}$ were dropped because "the superior interest of the Wakefield scenes crowded out other less interesting matter." Whether this be the actual reason for the omissions or not, it is impossible to say, but certainly such intermediate plays did exist at one time, because of references to them in the extant plays. ${ }^{150}$ The Preliminary Trial before Pilate is referred to in the scene of the Capture where Caiaphas bids the soldiers take Jesus to Pilate:

Now sen he is welle bett, weynd on youre gate,

And tell ye the forfett vnto sir Pylate. ${ }^{15}$

The Trial before Herod is referred to in the Final Condemnation before Pilate where one of the soldiers tells Pilate of his coming before Herod:

I hatue ron that I swett from sir herode oure kyng

With this man that wille not lett oure lawes to downe bryng. ${ }^{\text {st }}$

Whether the absence of a Nativity play in the Towneley cycle is to be ascribed to the loss of a play originally forming a part of the cycle, or whether the cycle never contained such a play, is more difficult to determine. Professor Cady ${ }^{153}$ offers a similar suggestion to that for the intermediate

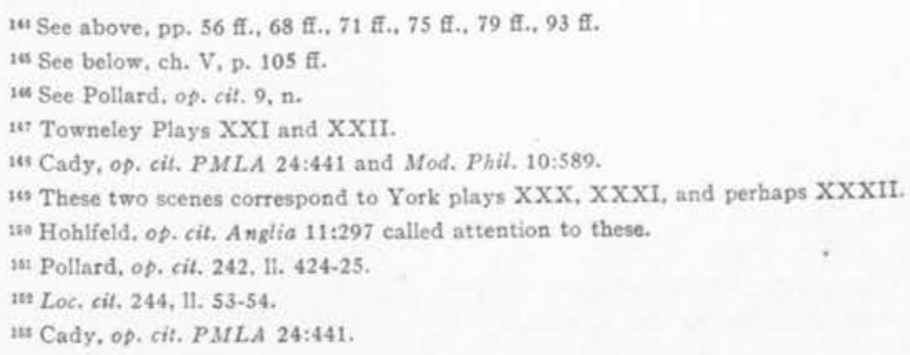


trial scenes, namely, that the greater interest taken in the productions of the Wakefield author, in this case the two Shepherds' plays, caused the dropping of the Nativity.

In certain cases, plays occurring in York but lacking in Towneley may be regarded as later insertions in the York cycle. Probably such plays as the Temptation, the Woman Taken in Adultery, and the Transfiguration were later additions. ${ }^{154}$ The extant records of the crafts responsible for Pilate's Wife's Dream, as well as the Temptation, point to the later incorporation of these plays. ${ }^{155}$ Undoubtedly, the Mary plays also represent a more extended separation and expansion at a late period in the development of the York cycle. ${ }^{156}$

\section{Conclusion}

Thus, certain similarities, not occurring in the other English cycles, are found in all the corresponding plays of York and Towneley, save one, the Purification. Because of the practical identity of five plays and the greater part of the sixth, there can be no question about the possibility of an original identity. These plays, it should be noted, do not appear in a single group or section of the cycle, but are scattered throughout, one play appearing in each of the four cyclic groups, the Pharaoh in the Old Testament, the Doctors in the Nativity, the Bearing of the Cross in the Passion, and the Resurrection proper in the Resurrection group. The Harrowing of Hell forms the connecting link between two of the groups, and the Last Judgment serves as the conclusion for the entire cycle. These plays, escaping revision, ${ }^{157}$ indicate, we believe, the relation originally existing in the two cycles, while the remaining plays, undergoing revisions, retain only in slighter degrees, traces of the original identity.

\section{Development of the Towneley Cycle}

With slight modifications, the general theory concerning the probable development of the Towneley cycle $^{158}$ is in keeping with the theory of an original identity of York and Towneley. The three stages pointed out by Mr. Pollard ${ }^{159}$ become, according to our theory, two stages. The early religious group of plays and the so-called York "borrowings" represent, we believe, the parent-cycle stage, and the work of the Wakefield author independent revisions in the Towneley cycle. Instead of an independent Towneley cycle, then, which incorporated certain York plays, we have extant in Towneley a part of the parent cycle in Mr. Pollard's so-called

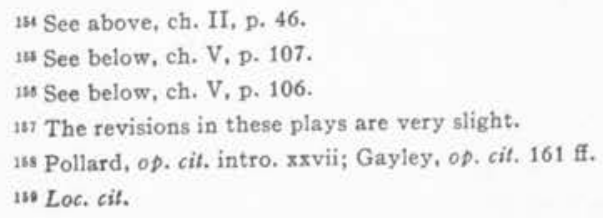


first and second groups. So far as the development of the Towneley cycle is concerned, there is no real difference between these two groups of plays, save that the first group probably represents an earlier stage in the development of the parent cycle than does the second group. So far as the theory of an original identity of York and Towneley is concerned, the only difference between these two groups of plays is that the plays in the first group either were, as we have seen, dropped from the York cycle or underwent revision there, while the plays in the second group remained practically unchanged.

For our present purpose it is not necessary to determine the number of successive revisions through which the plays of the Towneley cycle passed, or the order in which these revisions occurred. It will be sufficient to refer to the evidence already presented which appears to indicate that the couplets and perhaps also some of the quatrains, are a survival of the parent-cycle stage. ${ }^{160}$ On the other hand, the Wakefield author wrote after the separation of the two cycles. ${ }^{161}$

160 See especially the situation in the Last Supper, above, p. $79 \mathrm{ff}$.

tet See especially the situation in the A cony and Befrayal, above, p. 81 ff. Accepting Mr. Pollard's three stages, Professor Cady, (op. cit. JEGP 10:573 ff. and Mod. Phil. 10:599) argues that since editorial couplets do not occur in connection with the group of "direct York borrowings," but do in the other two groups, that the York borrowings were the latest addition to the Towneley cycle. But later (pp. 576-78) he invalidates this argument when he admits that in one case editorial couplets do appear in connection with the "York borrowings." Mrs. Frank (op. cit. Mod. Phil. 15:181 ff.) shows the improbability of his theory. 


\section{CHAPTER V}

\section{THE PROBABLE DATE OF SEPARATION}

The theory of an original identity of the York and Towneley cycles naturally calls for some consideration of the probable date of their separation. For this, we are dependent entirely upon the craft records of York during the fourteenth, fifteenth, and sixteenth centuries, ${ }^{1}$ since no records for the Towneley cycle are extant.

On the basis of these records, Davies ${ }^{2}$ and Miss Smith ${ }^{3}$ conclude that the Corpus Christi plays had existed in York many years previous to the end of the fourteenth century. The records of this period show that each craft had its assigned pageant to which members contributed, and that there existed a certain number of stations before which the plays were given. Even at that early date, the cycle had attained some fame outside the city portals, for King Richard II graced them with his presence in 1397. From the two Burton lists, ${ }^{4}$ the Register, and other documents, Miss Smith draws certain conclusions regarding the relation between the crafts and the Corpus Christi plays. "As business grew," she says, "a new craft would spring up, an old one decay and become too poor to produce its play, a new one must take its share; one craft trenching on the trade of another must share its burdens, sometimes two, or even three plays would be combined into one, sometimes a play would be laid aside and the craft to which it had been assigned must join in producing some other."

The recent publication of the complete text of the York Memorandum $B o o k^{6}$ makes it possible to gain more definite information concerning the actual conditions underlying the presentation of Corpus Christi plays under gild control. A detailed study of the rise of new crafts, of the decay of old ones, and of the combination of two or more, is a study of the rise and development of the Corpus Christi cycle. This is because each play was assigned to different crafts, which, from year to year, were responsible for the support and production of their respective pageants. In this way, plays came to be identified with certain gilds, and at least one case is recorded in which the gild is known by the name of the play for which it was

1 Liber diversorum memorandorum Civilatem Ebor. tangentium, beginning with 1376, has been published Book. Certain extracts from these records were previously published by Drake in his Eboractum, Davis, and in Municipal Records of the City of York, Miss Smith in her introduction to the York Mystery Plays. Riley in the Historical Manuscript Reports Commission 1:109.

Davies, ibid. app.

Miss Smith, ibid, intro, xix ff.

1415 list printed by Miss Smith, ibid. intro, xix ff.; undated list by Davies, ibid. app. $233 \mathrm{ft}$.

Smith, ibid. intro. xix.

- Ibid. 120 and 125, ed. by Miss Sellers. 
responsible. The Carpenters' Gild which produced the Resurrection is referred to as "the holy fraternite of the Resurrection."

The earliest records point to a still earlier period for organization of the Corpus Christi cycle. A record of 1376 refers to the storage of Corpus Christi pageants. ${ }^{8}$ The places at which the performances were given are referred to in 1394 as antiquitus assignatis. ${ }^{9}$ In 1378 , certain fines incurred by the Bakers were paid, half to the city chamber, half a la pagine des ditz Pestours de corpore cristi ${ }^{10}$ A record of 1388 mentions a donation of a hundred shillings to be used for "furnishing four torches to be burnt in the procession on the feast of Corpus Christi."11 Other crafts, mentioned before the end of the fourteenth century in connection with the payment of certain sums towards the support of Corpus Christi pageants, are the Plasterers (1390), ${ }^{12}$ the Cardmakers (1397?), ${ }^{13}$ the Cordwainers (1393?), ${ }^{14}$ the Bowers (1395), ${ }^{15}$ the Fletchers $(1388 ?),{ }^{16}$ the Lyttesters $(1390-1400 ?),{ }^{17}$ the Glasiers (or Verrours, 1394), ${ }^{18}$ the Sadlers (1398), ${ }^{19}$ and the Tailors (1386). ${ }^{20}$

Just when the York gilds assumed control of the Corpus Christi cycle, we do not know. It is difficult to determine what was meant by "ancient" in the 1394 record, already referred to, but Miss Smith's conclusion that the cycle originated as early as 1340-50 may well be correct. The Cambridge reference of 1350 to Corpus Christi plays, ${ }^{21}$ as well as the Chester

Tbid. 125 :intro, $x \times x$ viii.

- Tbid. 120:10. Two shillings were charged de uno tenemento, in quo tres pagine Corporis Christi po nuntur, per annum.

- Davies, ibid. app. 230.

Smith, ibid. intro, xxxii.

In 1399, the Verrours complained that the plays of Corpus Christi day were not performed as they should be, because they were given in too many places; it was therefore ordained that the number of sta. tions should be limited to twelve. See Davies, ibid. app. 231; Smith, ibid. intro. xxxii; Swr. Soc, 120:50.

10 Smith, ibid, intro, xxxi.

Ibid. 120:169. Here, the record is undated.

"Davies, ibid. app. 230.

II Ibid. 120:115.

a Ibid. 120:78-79. This date is determined by the dates of the enrollment of the members. Miss Sellers (op. cif. $78, \mathrm{n} .3$ ) has identified from the freemen's list certain of the masters mentioned in the ordinance; the earliest of the dates of enrollment being possibly 1368, the latest 1397 .

16 Ibid. 120:72-74. This date is determined by the dates of the enroliment of the masters. Miss Sellers (op. cit. 72 , n. 5) identifies from the freemen's list 51 of the 59 masters; the earliest of the dates being 1356 , the latest 1393 .

is Ibid. 120:52-54.

11. Ibid. 120:110. Isti constituciones composile fuerunt in die Lucie tirginis anro xii (December 13 , 1388 ?) is written at the top of the rigbt-hand cornet, according to Miss Sellers (n, 6, p. 110).

17 Ibid. 120:112. According to Miss Sellers (n. 2, D. 112), these enactments, judging from the dates of the enrollment on the freemen's list, "beiong to the last decade of the fourteenth century."

1" Ibid. 120:50-52. Davies, op. ci., app. 231-32 dates the ordinance concerning the stations at which Corpus Christi plays are given as 1394 .

11 Ibid. 120:90-1.

10 Ibid, 120:100. $3: 361$.

"See Chambers, op. cit. 2:344; Hist, MSS, 14:8, 133; Arnold, Memorials of St. Edmund's Abbey (R.S.) 
tradition of $1328,,^{22}$ point to the second quarter of the fourteenth century as the time in which the English cycles originated.

During the seventeen years from 1415 to 1432 , ordinances referring to Corpus Christi affairs are very numerous. It is easy to see that the success or the failure of a given play and, for that matter, its very existence as a part of the Corpus Christi cycle was largely dependent upon the financial status of the craft to which it had been assigned, or to the willingness of the craft to continue the play.

(1) A record of 1431 presents a complaint of the Masons $\mathrm{s}^{23}$ in which they ask to be relieved of the necessity of producing any longer their play, known as Fergus, on the ground that its subject-matter was not contained in Holy Scripture, and that it gave rise to more laughter and noise than devotion. They, therefore, petitioned that they might be granted another play, one which should be in accordance with Holy Scripture and could be produced and played in daylight. At the same time, the Goldsmiths ${ }^{24}$ appeared before the Council and on the plea that they had met with misfortune and "had become poorer than they were wont to be," begged to be given some assistance in the "grievous burden and enormous costs" entailed by the production of two pageants in the play of Corpus Christi. The council adjusted both matters by allowing the Masons to drop their play, Fergus, and to assume charge of the Herod play, one of the two maintained by the Goldsmiths. In this manner, the loss of Fergus is to be explained.25

(2) In 1422, the Painters, Stainers, Pinners, and Latoners ${ }^{26}$ suggested to the mayor and council that because of the excessive number of plays, it would be a distinct gain if the two plays for which they were responsible could be shortened and combined into one. Since the subject-matter of the one, the Nailing to the Cross, overlapped that of the other, the Raising of the Cross, they thought that the material of both could very well be combined. It was thereupon decreed that the Painters and Stainers should be exempt from bringing forth a play, but should pay five shillings annually to the Pinners and Latoners, who would undertake to produce the consolidated play. In keeping with this order, the later amalgamated play was entered in the register, while the two earlier versions, like that of Fergus, were discarded and lost. This was a partial return to the original form now seen in Towneley XXIII, in which the Crucifixion, includes the Nailing to the Cross, the Raising of the Cross, the Crucifixion and the Death and Burial.

(3) In 1417 , the Salsemakers, 27 who were responsible for the production of the play of the Hanging of Judas, appeared before the mayor and Council and complained that if those who were encroaching upon their trade were not forced to contribute to the support of their pageant, according to ancient custom, they would no longer be able to produce it. Whereupon, it was ordained that each artificer of the city who was not a candlemaker but who sold Parisian candles [by retail], should annually contribute

22 See Chambers, op, cit. 2:348.

21 Sur. Soc. 125:123-24; sce also intro. xlix.

2 Loc, cit.

s Burton's 1415 list (Smith, ibid. intro. xxvii) describes the play thus: Quatuor Apostoli portantes feretrum Marie, et Fergus pendens super feretrum, cum ii alifs Jadeis [cum ono Angelo].

a Sur. Soc, 125:102-4; see also intro, xix and xivii.

2) Riley's report in Hist. MS. Com. 1:109.

Smith, ibid. intro, xxiv.

Sur. Soc. 120:155. 
three pence. In $1422,{ }^{28}$ however, the Salsemakers amalgamated their play with those of other crafts, resulting in the pageant known as the Condemnation of Jesus Christ. At this time the following pageants were united: the pageant of the Salsemakers, in which Judas hanged himself and crepuit medius, the pageant of the Tilemakers, in which Pilate condemned Jesus to death, the pageant of the Turnors, Hayresters, and Bollers, in which Jesus was bound to a pillar and scourged, and the pageant of the Millers, in which Pilate and other soldiers played at dice for the clothing of Jesus. Ten years later, the Salsemakers retired from active participation in the production of the pageant and paid, instead, five shillings to the Tilers."

The play copied in the manuscript, ten, fifteen, or twenty years later, ${ }^{30}$ is a different one from that provided for in the 1422 order and again passed upon in the 1432 Council. Since the play of the Condemnation, as recorded in the Register, contains neither the Hanging of Judas nor the Throwing of the Dice, it seems reasonable to infer that either the dissatisfaction felt by the Salsemakers and Millers, or the poverty under which they suffered, increased to such an extent that they refused or were unable to bear longer the expense of their respective portions of the pageant and that, therefore, the parts for which they were responsible were thrown out. The cycle as we now possess it contains no incident connected with the Hanging of Judas. Nor can the few lines describing the Throwing of the Dice, the one scene occurring immediately after the arrival on Mount Calvary, and the other after the raising of the cross, be the original play offered by the Millers, for in the extant scenes the comic figure of Pilate plays no part. The description given him in the old York play seems rather to fit the Towneley play of the Talents, ubi Pilatus et alii milites ludebant ad talos pro vestimentis Jesu et pro eis sortes mittebant et ea parcicbantur inter se." The old York play may, indeed, be extant, in part at least in the Towneley cycle.

(4) In 1419,22 the Ironmongers, who, according to the 1415 Burton list, were responsible for the play of Mary Magdalene at the house of Simon the Leper, complained bitterly of their poverty-stricken condition. ${ }^{\text {a }}$ Because their pageant had fallen into a ruinous condition, which necessitated an annual reparation, they found it difficult to meet the additional expenses, and therefore, pleaded that apprentices be forced to contribute to the support of the pageant. They continued to give the play as late as 1433 or 1434 , because the play is included in the second Burton list. But since it was not entered in the Register, one may conclude that, a few years later, they found it impossible to continue its performance.

Thus, if the records preceding the year 1415 were complete, it is possible that certain plays absent in York, but included in the Towneley cycle, could be explained by the financial status of the crafts which were responsible for their production. Perhaps, the six Towneley plays, Isaac, Jacob, Prophetae, Octavian, Hanging of Judas, and Talents, were dropped from York because of the poverty of their respective crafts, or the unwillingness of the crafts to continue any longer the support of the pageants.

" Davies, op. cit. app, 235; Smith, op. cil. intro, xxv; Sur. Soc. 125:171.

to Sur. Soc: 125:173.

10 Thought to be 1430-40. See Miss Smith, ob, cil. intro, xy, xviii.

u See 1415 list, Smith, op. cit. xxv.

22 Through a mistake, Miss Sellers gives 1490 as the date of these ordinances. Since the ordinance, itself, bears the date anno Domini millesimo ecec nowodecimo, and advances the information that these orders were passed in the time of Thome Gare, maioris Ebor, who according to the Frecmen's List (Swr. Soc. 96) was mayor in 1419, there can be no doubt that the correct date of the ordinance is 1419.

2 The Ironmongers had always been a poor struggling gild, with only a few members, numbering in 1342 but twelve, and even seventy-seven years later, at the time of the above mentioned complaint, its enrollment had been increased only by the addition of s single member. See Swr. Soc. 120:intro. $x x x v i i$. 
The York cycle was not so fully developed at the end of the fourteenth century as it was in 1415, according to the Burton list. The fact that the Drapers in 1403 contributed to the pageant of Pharaoh in conjunction with the Hosiers, ${ }^{34}$ but in 1415 were in charge of the Death of Mary ${ }^{35}$ is an indication of the later elaboration and separation of the Mary plays. Although we possess no other records pointing to a less developed cycle at York than that described in the two Burton lists, 1415 to 1431, there is no reason to believe that the parent cycle, which probably belonged at York, was not actually developed, in part at least, from liturgical plays. The reference of 1255 to the Pastores and Magi ${ }^{36}$ may be taken as evidence for the existence, at that time, of a group of liturgical plays centering about the Nativity.

Though no reference to the transitional development of the York cycle has as yet been found, probably it passed through the same stage as that represented by the Shrewsbury Fragments. Such an assumption is strengthened by the resemblances between the two cycles pointed out by Professor Skeat. ${ }^{37}$

A stage in the development of cycles earlier than that of York or Towneley is seen in the true-Coventry plays. Apparently but a single step intervenes between the stage represented by the Nativity group of the Coventry plays, in which individual incidents have already attained some elaboration within the limits of a single play, and the stage represented by the Towneley cycle, where the same incidents, receiving further amplification and adornment, have been made into separate plays and put in the charge of different gilds. This further growth was probably due to the development of the individual crafts and their demand for a share in the Corpus Christi productions. ${ }^{38}$

"Riley, Hist. MS. Report 1:109.

Smith, ibid, intro, $\mathrm{xx} \mathrm{n} .3$.

Sur. Soc. 120:154.

ss See Burton list, Smith, op. cil. intro.

" Lincoln Statutes 2:98.

Chambers, ibid. 2:399.

Waterhouse, Non-English Cycle Plays EETSES 104: intro. xxv.

Craig, ibid. Journ. Eng. and Ger. Phil. 13:9; Mod. Phil. 10:485.

" Skeat, Acad. 1890.

Waterhouse, ibid. EETSES 104 intro. xx.

3s The York craftsmen did not begin to form themselves into societies much before the beginning of the fourteenth or, at the earliest, the end of the thirteenth century. (See Sur.Soc.120:xxiv and 125:xxviii.) The merchant gild of York was organized certainly as early as 1200 and was at first so strong and influential that it dominated the city council. The Weavers had obtained their incorporation even earlier. (See Sur. Soc. 120:xxvii.) The establishment shortly afterwards of the Tailors, Tapiters, and Lyttesters, all of which were large and influential gilds, gave to the cloth-making crafts a predominance which they never relinquished. The architectural development of the fifteenth century led to great activity in the building trades. The Glasiers, Carpenters, Tilers, and Plasterers appear many times in the council chamber for the ratification of their ordinances. (See Sur. Soc, 125: intro. xxviii.) By the end of the century, the metal-working gilds were also developed and differentiated-the Cutlers, Pinners, Goldsmiths, Girdlers, Founderers, Pewterers, etc. (See Sur. Soc. 120: intro. xxxiv.) It is very likely that the high development which the Corpus Christi cycle attained, at York, was due entirely to the increased demand created by newly formed gilds for individual plays. 
Some intermediate stage, like that to be seen in the Towneley cycle, must have intervened between the stage represented by true-Coventry and that represented by York in 1415. In certain parts of the Towneley cycle, it is possible to see that stage of development, in which the earlier plays had already begun to break up, but had not yet reached the highly developed stage represented by the Burton lists. The incidents presented in the Towneley Creation group are elaborated into six distinct plays in York and the Towneley Passion group of four plays into eight plays in York. Single Towneley plays have been separated into two or three distinct pageants in York: the Towneley Conspiracy into three, the Towneley Scourging into two, the Towneley Crucifixion into two, the Towneley Resurrection into two, the Towneley Magi into two, and the Towneley Noah into two. It thus becomes evident that the Towneley cycle represents that intermediate stage of development through which the York cycle must surely have passed before it reached its present highly developed stage.

Because of the incompleteness of the York records, we can do little more than suggest that the York cycle before 1400 did not include all of the extant plays. Two crafts, the Tapiters, ${ }^{39}$ and the Smiths, ${ }^{40}$ responsible for plays in $1415,{ }^{41}$ mention before this date only the Corpus Christi lights which they provide. If they had also possessed pageants at this time, it seems probable that they would have mentioned them in connection with the provisions for the lights, but their failure to do so may be taken as negative evidence that they did not. Because of the close identity of a given craft with a particular play, we may infer that before the end of the century the plays for which these crafts were later responsible, namely, Pilate's Wife's Dream and the Temptation, were not included in the York cycle. Since Towneley contains neither of these plays, the natural inference is that they did not form a part of the parent cycle.

Two of the York crafts, the Plasterers ${ }^{42}$ and the Cardmakers, ${ }^{43}$ responsible for two plays later revised in York, ${ }^{44}$ the Creation to the Fifth Day and the Creation of Adam and Eve, mention payments for the support of their pageants as early as 1390 and 1397 respectively. Thus it is evident that the division into separate units of the Creation play, now extant in a single play in Towneley, had already begun in York by the year 1390. The separation of the York and Towneley cycles must, then, have occurred before this date. The work of the Wakefield writer, generally assigned to

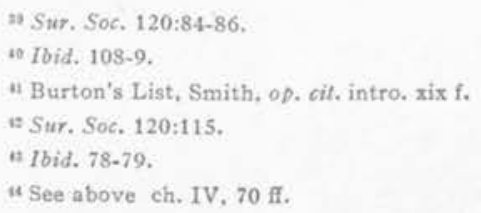


the first of the fifteenth century or the last of the fourteenth century, ${ }^{45}$ also points to the independent existence of the Towneley cycle at that time. Since he revised York material, ${ }^{46}$ it seems safe to conclude that the separation of the York and Towneley cycles occurred before the end of the fourteenth century, and according to the extant record of the York craft of the Plasterers, cited above, at least before the year 1390.

4s Sur. Soc. edition of the Towneley Mysteries intro. x.

Pollard, ibid. intro, xxvi-xxvii.

Hope Traver, Relation of Musical Terms in Woodkirk Shepherd's Plays to the Dates of Their Composition Mod. Lang. Notes 20:1.

"See above, ch. IV, p. 101. 


\section{BIBLIOGRAPHY}

Adam: drame anglo-normand du XII ${ }^{e}$ siècle. Edited by Victor Luzarche. Tours. 1854 .

A Elfric. Homilies. Edited by B. Thorpe for Aelfric Society. 2 volumes. 1834-36.

Anz, Heinrich. Die lateinischen Magierspiele. Leipzig. 1905.

Apocryphal Gospels, Acts, and Revelation. In Ante-Nicene Christian Library.

Edited by A. Roberts and J. Donaldson, 16. Edinburgh. 1870.

Apocryphal Gospels. Translated by Harris Cowper. London. 1910.

BAtES, K. L. English religious drama. New York and London. 1893.

BAtes-Godfrey. English drama: a working basis. 1896.

Blickling homilies. Edited by R. Morris.

BRANDL, A. Quellen zur Geschichte des weltlichen Dramas in England vor Shakespeare. Strassburg. 1898.

BrotaneK. Abraham and Isaac, Noah's Arche. Anglia 31:165.

Brown, Carteton. The Towneley play of the doctors and the Speculum Christiani. Modern Language Notes 31:223.

Bullen, A. H. A collection of Old English plays. 4 volumes. London. 1885-89.

Bunzen, A. Ein Beitrag zur Kritik der Wakefielder Mysterien. Kiel. 1913. (Criticized Angl. Bbl. 17:161, Luick).

Cady, Frank. The liturgical basis of the Towneley mysteries. Publications Modern Language Association 24:419.

- The passion group in Towneley. Modern Philology 10:587.

- The Towneley couplets and quatrains. Journal of English and Germanic Philology 10:572.

- The Wakefield group in Towneley. Journal of English and Germanic Phi$\operatorname{lolog} y 11: 244$.

Cambridge history of English literature. Edited by A. W. Ward and others. New York and Cambridge. 1910. Volumes I, II, V.

Chambers, E. K. The medieval stage. 2 volumes. Oxford. 1903.

Chester plays. Edited by Thomas Wright. 2 volumes. London. 1843.

- Plays 1-13. Edited by H. Deimling. Early English Text Society 62, London. 1903.

CLARKE, S. W. The miracle play in England: an account of the early religious drama. London.

Coblentz, H. E. Rime-index to the York parent cycle. Publications Modern Language Association 10:487.

- Some suggested rime emendations. Modern Langaage Notes 10:77.

CotLier, J. P. The history of English dramatic poetry. London. 1831.

Cone old plays. London. 1851.

Comestor, P. Historia scholastica. In Migne's Patrologia Latina. Paris. 1844.

Cоoк, A. S. A remote analogue to the miracle play. Journal of English and Germanic Philology $4: 420$.

Covrthope, W. J. A history of English poetry. 6 volumes. New York and London. 1895-1910.

Coussemaker, Edmond. Drames liturgiques du moyen age. Paris. 1871.

Craig, Hardin. Two Coventry Corpus Christi plays. Early English Text Society 87, extra series. London. 1902.

- The origin of the Old Testament plays. Modern Philology 10:473.

- The Corpus Christi procession and the Corpus Christi play. Journal of English and Germanic Philology 13. 
Craigre, W. A. The Gospel of Nicodemus and the York mystery plays. Furnivall Miscellany. Oxford. 1901.

Creizenach, W. Geschichte des neueren Dramas. Second edition. Halle. 1911.

Cron, BERTHOLD. Zur Entwicklungsgeschichte der englischen Misterien alten Testaments. Marburg Dissertation. 1913.

Cursor mundi. Early English Text Society 57, 69, 101, 59, 62, 66, 68. Edited by R. Morris. London. 1874-93.

Davidson, Charles. Studies in the English mystery plays. Yale Dissertation. Transactions of Connecticut Academy of Sciences 9:1.

- Concerning English mystery plays. Modern Language Notes 7:339.

DAvies, RoBert. Extracts from the municipal records of the city of York of the fifteenth century. London. 1843.

Digby plays. Edited by F. J. Furnivall. Early English Text Society 70. London. 1890.

Dodsley, Robert. A select collection of Old English plays. Edited by Hazlitt. London. 1874-76.

Drake, Francis. Eboracum. London. 1836.

DU MERIL, E. P. Origines latines du théatre moderne. 1849. Facsimile reprint. Leipzig. 1897.

Ebert, A. Allgemeine Geschichte der Literatur des Mittelalters im Abendlande 3. Leipzig. 1880-89. 1859 .

Emerson, O. F. The legends of Cain. Publications Modern Language Association 21:831.

Foster, F. A. See also Northern Passion.

The mystery plays and the Northern Passion. Modern Language Notes

26:169-71.
A study of the Northern Passion and its relation to the cycle plays. Bryn Mawr dissertation. London and Bungay. 1914.

French, JoHn. A note on the miracle plays. Modern Language Notes 19:31.

Froning, R. Das Drama des Mittelalters. In Kürschner, Deutsche NationalLiteratur 14, 3 parts. Stuttgart. 1891.

Furnivall miscellany. An English miscellany presented to Dr. Furnivall in honor of his seventy-fifth birthday. Oxford. 1901.

Gayley, C. M. Plays of our forefathers. New York. 1907.

- Representative English comedies. 3 volumes. New York. 1907-14.

- The earlier miracle plays of England. International Quarterly 10:108.

- The later miracle plays of England. International Quarterly 12:67.

Gerould. Moll of the Prima Pastorum. Modern Language Notes 19:225.

Gross, Charles. The gild-merchant. Oxford. 1890.

Guest, Edwin. History of English rhythms. Edited by W. W. Skeat. London. 1882 .

HaLl, JosepH. The York plays. Englische Studien 9:449.

HAlliwell, J. O. See Ludus Coventriae.

HALliwe The romance of the Emperor Octavian. Percy Society. London. 1844.

HazlitT-Warton. A history of English poetry. 4 volumes. 1871.

Hemingway, S. B. English nativity plays. New York. 1909.

Hertrrich, O. Studien zu den York Plays. Breslau Dissertation. 1886.

Hesslers. Evangelium Nikodemi. Beilrage, Paul und Braunes 24:85. Helm. 
HiBbert, F. A. The influence and development of English gilds as illustrated by the history of craft gilds of Shrewsbury.

Historical manuscripts commission reports, 1, 109. London. 1874.

HOHLFELD, A. Die altenglischen Kollektivmysterien. Anglia 11:219. Two Old English mystery plays on the subject of Abraham's sacrifice. Modern Language Notes 5:222.

Holthausen, F. Beitrage zur Erklärung und Textkritik der York Plays. Archiv für das Studium der neuern Sprachen 85:411.

— Nachtrag zu den Quellen der York Plays. Herrig's Archiv 86:280.

- Noah's ark, or the shipwright's ancient play or dirge. 1897.

Hone, Writam. Ancient mysteries described. London. 1823.

Horstmann, C. Sammlung altenglischen Legenden. Heilbron. 1881.

KAluzA, Max. Englische Metrik in historischer Entwicklung. Berlin. 1909.

KAMann, P. Uber Quellen und Sprache der York Plays. Leipzig Dissertation. 1887. Anglia 10:189.

Kretzmann, P. E. The liturgical element in the earliest forms of the medieval Drama. Minnesota Dissertation. Minneapolis. 1916.

JENNEY, ADELINE M. A further word as to the origin of the Old Testament plays. Modern Philology 13:59.

KLerN, J. L. Geschichte des Dramas, 3, 12, 13: Das englische Drama. Leipzig. 1876.

Kölbing, E. Beiträge zur Erklärung und Textkritik der York Plays. Englische Studien 20:179.

— On Pollard's miracle plays. Englische Studien 16:279.

Körting, G. Grundrisz der Geschichte der englischen Literatur. Third edition 1899.

LANGe, Carl. Die lateinischen Osterfeiern. München. 1887.

LEACH, A. F. Some English plays and players. Furnivall Miscellany. Oxford. 1901.

Lincoln statutes (statutes of Lincoln Cathedral). Arranged by H. Bradshaw; edited by C. Wordsworth. 2 volumes. 1892-97.

Ludus Coventriae or Coventry mysteries. Edited by J. O. Halliwell. London. 1841.

Luick, K. Zur Textkritik der Spiele von York. Anglia 22:384.

MANi.y, J. M. Specimens of pre-Shakespearean drama. 2-volumes. Boston and London. 1897.

MARriot, WnLtam. English miracle plays and mysteries collected. Basel. 1838.

Middle English Harrowing of Hell and Gospel of Nicodemus. Edited by W. H. Hulme. Early English Text Society 100, extra series.

Migne, J. P. Patrologia Latina. 221 volumes. Paris, 1844.

Monk, F. J. Deutsche Schauspiele des Mittelalters. Karlsruhe. 1846.

MOORE, E. English miracle plays and moralities. London. 1907.

Norris, E. Ancient Cornish drama. 2 volumes. Oxford. 1859.

Non-cycle mystery plays. Edited by Waterhouse. Early English Text Sociely 104, extra series.

Northern Passion. Edited by F. A. Foster. Early English Text Society 145 and 147. London. 1914.

Norwich plays: the grocer's play. Edited by R. Fitch. Norwich. 1856.

PAul, H. Grundrisz der germanischen Philologie. Strassburg. 1891-93.

Peacock, M. H. The Wakefield mysteries: the place of representation. Anglia 24:509.

Pollard, A. W. See Towneley mysteries. 
Polla RD, A. W. English miracle plays, moralities, and interludes. Oxford. 1890. SAINTsbury, G. E. A history of English prosody. London and New York. 1906. Schipper, Јаков. Altenglische Metrik. Bonn. 1881,

Sharp, Thomas. On the pageants or dramatic mysteries anciently performed at Coventry. Coventry. 1825.

- See Digby plays.

Skeat, W. W. Joseph of Arimathea. Athenaeum 11:779.

Smith, Lucy Toulmin. See the York plays.

Play of Abraham and Isaac. Anglia 7:316.

Smith, Toulmin. The English gilds. Early English Text Society 40. London. 1870.

Spencer, M. L. Corpus Christi pageants in England. New York. 1911.

STODDARD, F. H. References for students of miracle plays and mysteries. University of California Library Bulletin, no. 8. 1887.

Story of Genesis and Exodus. Edited by Morris. Early English Text Society 7. Swenson, E. L. An inquiry into the composition and structure of Ludus Coventriae. University of Minnesota. Minneapolis. 1914.

Surtees Society.

The correspondence of Dr. Mattew Hutton, Archbishop of York. Edited by Raine. Vol. 17.

Manuale et processionale ad usum insignis ecclesiae eboracensis. Edited by Henderson. Vol. 63.

Register of the freemen of the City of York. Vols. 96 and 102.

Register of the guild of Corpus Christi in the city of York. Edited by R. H. Skaife. Vol. 57.

Testamenta eboracensia. Wills illustrative of the history, manners, language, statistics, etc. of the province of York from 1300 downwards. Edited by Raine. Vols. 4, 26, 30, 45, 53, 79, 106.

Towneley mysteries. Vol. 3 .

York breviary. Edited by S. Lawley. Vols. 71, 75.

York memorandum book. Edited by M. Sellers. Vols. 120 and 125.

York missal. Edited by Henderson. Vols. 59, 60.

York pontifical. Edited by Henderson. Vol. 61.

Taylor, George C. An English Planctus Mariae. Modern Philology 4:605.

- Relation of the English Corpus Christi play to the Middle English lyric. Modern Philology 5:1-38.

TEN BRINK, BERnHARd. History of English literature. Translated by L. D. Schmitz. New York. 1893-96.

Towneley mysteries.

Edited by Pollard. Early English Text Society 71, extra series. London. 1897.

Surtees Society Publications. London. 1836.

Child, The second shepherds' play. Boston. 1910.

Hemingway, English nativity plays, prints plays 10, 11, 12, 13.

Manly, Specimens of pre-Shakespearean drama, prints plays 3, 5, 6, 13.

Marriott, English miracle plays, prints plays $8,13,23,25,30$.

Cook reader, prints play 13 .

Athenaeum $11: 284$, prints play 24 .

Shakespeare Jahrbuch, prints play 24.

Smith, York plays, prints plays $8,18,25,26,30$, for comparison with York.

Everyman with other interludes, prints plays $13,23,25$ (modern rendering). In Everyman Library. 1909.

Pollard, English miracle plays, prints play 13. 
Collier, Five miracle plays, prints play 13. London. 1836.

Douce, Roxborough Club, prints play 30.1822 .

Matzner, Altenglische Sprachproben, 1, prints play 3.

Zupitza, Ubungsbuch, prints play 3.

Valke, Der Tod des Abel. Leipzig. 1875.

TrAver, Hope. The relation of musical terms in the Woodkirk shepherds' play to the date of their composition. Modern Language Notes 20:1.

Ungemach, H. Die Quellen der funf Chester Plays. Erlangen. 1890.

Utesch, Hans F. Die Quellen der Chester Plays. Dissertation Kiel. 1909.

VAN DER GRAF. Miracles and mysteries in southeastern Yorkshire. Englische Studien $34: 228$.

Viel Testament, Le mystère du. Edited by J. de Rothschild and E. Picot. Soricté des anciens textes françaises. 6 volumes. Paris. 1878-91.

Victoria history of the counties of England. Vol. 3 deals with Yorkshire. Edited by W. Page. London. 1913.

WARD, A. W. History of English dramatic literature. London. 1875. Second edition. 3 volumes. 1899.

Wel..s, John E. A manual of the writings in Middle English. New Haven and London. 1916.

York mystery plays.

Edited by Miss Lucy Toulmin Smith from the Ashburnham Manuscript. Oxford. 1885.

Skryvener's pagent: the incredulity of Thomas, published by Collier, Camden Miscellany, 4, and by Croft in Excerpta Antiquae.

Play 14 in Cook reader.

Plays $12,13,14,15$ in Hemingway, English nativity plays.

Plays 38,48 in Manly's specimens 1.

Play 1 in Pollard's English miracle plays.

Note on the Manuscript in Academy 530:9. 1822.

Zupitza, Julius. The York plays. Deutsche Literatur Zeitung 6:1304. Berlin. 1880. 